\title{
Экономическая социология
}

электронный журнал

www.ecsoc.msses.ru

Том 3, № 2, 2002

Главный редактор журнала - Радаев Вадим Валерьевич, д.э.н., зав. кафедрой экономической социологии ГУ-ВШЭ, проректор ГУ-ВШЭ; директор Интерцентра Московской школы социальных и экономических наук. E-mail: radaev@hse.ru

Редактор, администратор сайта - Лукьянчук Михаил Борисович, аспирант ГУ-ВШЭ, E-mail: ecsoc@msses.ru

Проект осуществляется при поддержке

Московской высшей школы социальных и экономических наук (www.msses.ru)

Журнал выходит пять раз в год.

№ 1 - январь,

№ 2 - март,

№ 3 - май,

№ 4 - сентябрь,

№ 5 - ноябрь. 


\section{Содержание}

Вступительное слово главного редактора.............................................

$\underline{\text { Интервью }}$

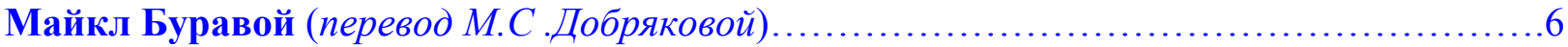

Дьердь Ленгель (перевод М.С. Добряковой)............................................. 12

Новые тексты

Волков В.В.

Силовое предпринимательство в современной России. Главы 2 и 3.

Шевчук А.В.

Постфордистские концепции как исследовательская программа....

Новые переводы

Поланьи К.

Экономика как институционально оформленный процесс (перевод М.С. Добряковой).... 62

Взгляд из регионов

Бредникова О., Паченков О.

Этничность «этнической экономики» и социальные сети мигрантов

Дебютные работы

Скурятина Е.

Сберегательные стратегии населения: основные понятия и операционализация....

Профессиональные обзоры

\section{Пейшоту Ж., Маркеш Р.}

Экономическая социология в Португалии (перевод М.С. Добряковой)

Новикова Е.Г.

Обзор интернет-ресурсов - 6. Классика экономической социологии, история и методология экономической социологии, социальная стратификация

Новые книги

Клямкин И., Тимофеев Л. Теневая Россия: Экономико-социологическое исследование (С.Ю. Барсукова)

Исследовательские проекты

Создание виртуального Центра экономической социологии ЭКСОЦЕНТР

(B.B. Радаев).

Создание виртуального центра «Социология - Методы» (А.Ермолаев).

Учебные программы

Радаев В.В.

Современная экономическая социология

$\underline{\text { Конференции }}$

При каких условиях начинают работать формальные правила в социально-экономической сфере? (Обзор работы секции IX ежегодного международного симпозиума «Куда идет Россия?.. Формальные институты и реальные практики» (И.П.Попова)......135 Социальная политика: реалии XXI века (Добрякова М.С.).............................. 140 


\section{$\boldsymbol{V R}$ Вступительное слово главного редактора}

Дорогие читатели, наша жизнь станет еще более веселой и красочной. Уже в конце весны этого года рядом с журналом «Экономическая социология» появится родственный сайт виртуального центра ЭКСОЦЕНТР (Центр экономической социологии). И очень скоро по объему ресурсов он превысит масштаб журнала и множества других профессиональных сайтов в нашей области. Работа вступает в завершающую фазу. Об открытии сайта мы, разумеется, вам сообщим (и не раз). А пока с исходными данными будущего сайта можно ознакомиться в рубрике «Исследовательские проекты».

Что же касается нашего журнала, то его выпуск продолжится в прежнем объеме, и размещаться он будет по прежнему адресу. Кстати, подоспел очередной номер.

Рубрика «Интервью» уже набрала обороты. Мы публикуем две очередные беседы. Первая - с Майклом Буравыл. Майкл - декан факультета социологии университета Беркли (Калифорния). Но важнее другое. Он хорошо известен российским социологам, ибо много лет занимается именно Россией. Буравой - индустриальный социолог марксистского направления. Он не считает себя собственно экономсоциологом, но, несомненно, близок этому направлению. Вдобавок, в 2001 г. он вступил в интересные дебаты с экономсоциологами на страницах журнала American Journal of Sociology.

Наш второй собеседник - из Восточной Европы. Речь идет о ведущем специалисте по экономической социологии в Венгрии - Дьерде Ленгеле, который сделал очень многое для ее развития в Будапештском университете экономических наук. Вместе с Ричардом Сведбергом Ленгель также основал Исследовательскую сеть «Экономическая социология» в рамках Европейской социологической ассоциации. С тех пор сеть постоянно расширяется, а ее заседания на европейских конгрессах становятся все интереснее.

В рубрике «Новые тексты», как было обещано, мы продолжаем публиковать главы новой книги Вадима Волкова о силовом предпринимательстве. В данном номере вашему вниманию будут представлены вторая и третья главы книги. Речь пойдет о теоретических подходах в политической экономии силы, а также об эволюции охранных услуг в России последнего десятилетия.

Далее следует материал Андрея Шевчука (ГУ-ВШЭ), посвященный проблемам постфордистских дебатов. Эта область исследований в России пока явно недостаточно освоена.

В рубрике «Новые переводы» предлагается первая часть одного из основополагающих текстов Карла Поланьи о двух значениях «экономического». Безусловно, Поланьи является одной из классических и широко цитируемых фигур в экономической социологии. Ныне наблюдается своего рода ренессанс его трудов и в европейских странах, и в США. Так, в 2001 г. вышло новое издание его основной книги «Великая трансформация» с предисловиями Дж. Стиглица и Фреда Блока. В России же Поланьи пока не столь широко известен. Хотя уже изданы, по крайней мере, два перевода из его наследия (в журнале THESIS и книге «Неформальная экономика» под ред. Т. Шанина). Что же касается «Великой трансформации», то ее перевод, объявленный Институтом «Открытое общество», все никак не завершится. Полный перевод текста, предлагаемого в данном номере, увидит свет позднее - в рамках подготавливаемой нами хрестоматии «Западная экономическая социология».

В рубрике «Взгляд из регионов» размещена работа Ольги Бредниковой и Олега Паченкова (Центр независимых социологических исследований, Санкт-Петербург). Работа выполнена в рамках проекта ЦНСИ «Кавказцы в российском городе: стратегии 
интеграции на фоне ксенофобии» (1997-1999 гг.) и посвящена исследованию социальных сетей, сформированных экономическими мигрантами. Авторы размышляют об этничности «этнической экономики». Результаты исследования были представлены на международном семинаре «Этничность и экономика в постсоциалистическом пространстве» (Санкт-Петербург, 2000 г.), материалы которого вошли в одноименный сборник [Под ред. Бредниковой О., Воронкова В., Чикадзе Е. СПб.: ЦНСИ, 2000; http://www.indepsocres.spb.ru/sbornik8/8r bred.htm]. Статья публикуется с любезного согласия авторов.

Размещаемый в рубрике «Дебюты» текст - часть дипломной работы выпускницы Государственного университета - Высшей школы экономики Еленьл Скурятиной. Он посвящен подходам к определению стратегий финансового поведения и способам операционализации этих стратегий.

В рубрике «Профессиональные обзоры» предлагается очередной страновой материал «Экономическая социология в Португалии», переведенный из Европейского Ньюслеттера «Экономическая социология» (авторы - Ж. Пейшоту и Р. Маркеш). Несколько лет назад авторы организовали в Португалии одну из наиболее крупных конференций экономсоциологов в Европе. Выступали они и у нас в Москве на конференции «Экономическая социология на пороге третьего тысячелетия» (январь 2000 г.) [о конференции см.: Том 1, №1 (2000)].

Е.Г. Новиковой подготовлен шестой обзор электронных ресурсов для экономсоциологов. Это первый тематический обзор. Выбраны три темы: классические тексты, история и методология экономической социологии, социальная стратификация. В дальнейшем мы предполагаем продолжить тематическую систему поиска и подготовить серию обзоров в соответствии с разработанным нами оригинальным предметным каталогом по экономической социологии.

В разделе «Новые книги» предлагаем вашему вниманию рецензию С.Ю. Барсуковой на книгу, опубликованную ранее в журнале «Pro et Contra». Обычно мы не размещаем уже опубликованные тексты. Но в данном случае (с любезного согласия руководства журнала) мы делаем исключение. Ибо рецензии, выходящие за дежурно-повествовательные рамки, пишутся у нас, увы, нечасто.

В рубрике «Исследовательские проекты» мы знакомим вас с двумя родственными проектами создания новых виртуальных центров в области социологии. Разработка обоих проектов была начата двумя исследовательскими командами параллельно (не сговариваясь) по сходной идеологии. Речь идет о создании ресурсных центров, которые будут не просто пассивными хранилищами информации и текстов, но намерены активно производить профессиональные ресурсы. Первый - проект создания ЭКСОЦЕНТРА (Центра экономической социологии). Руководитель - В.В. Радаев. Второй - проект создания виртуального центра «Социология - методы». Руководитель - Ю.Н. Толстова. Сайты обоих центров будут открыты для пользователей уже в этом году.

Далее в рубрике «Учебные программы» мы размещаем «Современную экономическую социологию» B.B. Радаева. Это совершенно новая программа, выходящая далеко за рамки книги «Экономическая социология: курс лекций» [М.: Аспект Пресс, 1997]. Ее основная часть посвящена новым и новейшим направлениям западной экономической социологии. Лекционный курс по этой программе впервые был впервые прочитан осенью 2001 г. на факультете социологии ГУ-ВШЭ.

В рубрике «Конференции» И.П. Поповой подготовлен обзор выступлений экономикосоциологической секции IX Международного Симпозиума Интерцентра «Куда идет Россия?». В этом году секция признана особенно успешной. Удачная тема, сильный состав докладчиков, фокусированное обсуждение, тон которому задавали 
институциональные экономисты А. Аузан, Р. Капелюшников и В. Найшуль, - все это вызвало заслуженный интерес. Пожалуй, никогда еще эта секция не привлекала к себе столько внимания.

В заключение М.С. Добряковой предлагается краткий информационный материал о конференции Независимого института социальной политики.

Следующий номер у нас десятый, юбилейный. Ждем ваших поздравлений. 


\section{$\underline{\text { Интервью }}$}

$\boldsymbol{V R}$ Мы публикуем две очередные беседы. Первая - с Майклом Буравылм. Майкл - декан факультета социологии университета Беркли (Калифорния). Но важнее другое. Он хорошо известен российским социологам, ибо много лет занимается именно Россией. Буравой - индустриальный социолог марксистского направления. Он не считает себя собственно экономсоциологом, но, несомненно, близок этому направлению. Вдобавок, в 2001 г. он вступил в интересные дебаты с экономсоциологами на страницах журнала American Journal of Sociology.

Наш второй собеседник - из Восточной Европы. Речь идет о ведущем специалисте по экономической социологии в Венгрии - Дьерде Ленгеле, который сделал очень многое для ее развития в Будапештском университете экономических наук. Вместе с Ричардом Сведбергом Ленгель также основал Исследовательскую сеть «Экономическая социология〉 в рамках Европейской социологической ассоциации. С тех пор сеть постоянно расширяется, а ее заседания на европейских конгрессах становятся все интереснее.

\section{МАЙКЛ БУРАВОЙ. 17 сентября 2002 г. ${ }^{1}$}

Я ожидал Буравого в его собственном кабинете, который он любезно предложил мне использовать на время моего пребывания в Беркли. Майкл появился на пороге в шлеме с велосипедом в руках. Записывать интервью в его комнате оказалось невозможным (за стеной работал отбойный молоток), и нам пришлось перейти в его деканский офис в противоположном конце здания. По пути он утверждал, что строители-ремонтники работают «совершенно по-советски». И Буравой знает, что говорит. Он провел немало времени, проводя включенное наблюдение на заводах в Москве и Сыктывкаре в качестве простого рабочего.

- Ваши исследования очень интересны и важны для экономсочиологов. Связываете ли Вы себя в какой-то степени с экономической социологией как особой исследовательской областью?

- Думаю, да. Я социолог, и я изучал экономику. Так что так или иначе я должен быть связан с экономической социологией.

- Что общего между Вашим подходом и экономико-соииологическим подходом, и чем они различаются?

- Мой подход - марксистский, а марксизм всегда перекликался с социологией, и особенно с экономической социологией, поскольку марксизм всегда был сосредоточен прежде всего на вопросах хозяйства. Можно даже предположить, что экономическая социология - своего рода реакция на возрождение марксизма в 1970-е и отчасти в 1980-е гг. Акцент в то время делался главным образом на проблемах трансформации производства, они стояли в центре капиталистического хозяйства (как, впрочем, и социалистического). А сейчас социология и экономическая социология все больше внимания уделяют исследованию обмена и рынков.

\footnotetext{
${ }^{1}$ Перевод М.С. Добряковой.
} 
Мне кажется, что экономическая социология (я включаю сюда и институционализм) впитала многое из социологии Э. Дюркгейма. В частности, она исследует предпосылки существования рынков так же, как это делал Дюркгейм и как это позднее делал М. Грановеттер. Думаю, она многое почерпнула также из работ К. Поланьи. И наверное, своим статусом критической дисциплины экономическая социология обязана идее Поланьи об овеществлении [commodification]. Т.е. я не считаю, что это единственное, что исследователи взяли у Поланьи. Они позаимствовали, скорее, не присущее ему негативное восприятие рынка, а представление о перенасыщенной институтами [overinstitutional] инфраструктуре, необходимой для функционирования рынка.

- И понятие фиктивных товаров.

- Совершенно верно.

- Но современная экономическая сочиология в принципе занимается производственными рынками. Например, Хэррисон Уайт много писал о них. И новая книга Нила Флигстина, о которой мы недавно говорили, посвящена строению производства.

- Вы имеете в виду «Архитектуру рынков» ${ }^{2}$ ?

$-Д a$.

- Но ведь он не уделяет особого внимания тому, как люди производят товары, не правда ли?

- Мне кажется, что под «производством» Вы понимаете нечто более узкое, а именно: «труд», «трудовые отношения».

- В общем, да, акцент на производстве часто предполагает изучение именно трудовых отношений, отношений между капиталом и трудом. Я провожу достаточно грубое различие между производством и обменом (возможно, сейчас оно уже не принято). С одной стороны, есть производство, которое означает изготовление материальных вещей или предоставление услуг. А с другой стороны находится обмен, который играет решающую роль в процессе потребления, распределения и функционирования рынков. Я полагаю, можно провести различие между производством и обменом, или между процессом труда и рынками.

Поэтому я считаю, что нынешняя экономическая социология - это новое концептуальное образование. Да, конечно, Смелсер еще давно говорил об экономической социологии. Но та экономическая социология, которая формируется сегодня, и то, что в соответствующей новой секции Американской социологической ассоциации называется «экономической социологией», - это нечто новое. Я думаю, новым является именно этот акцент на проблематике рынков - в отличие от того, что мы называли производством, классовыми отношениями. И что складывало более марксистски ориентированную традицию.

- В своей рецензии на книги Дэвида Старка, Ивана Селеньи и их соавторов ${ }^{3}$ Вы критикуете неоклассическую сочиологию и экономическую социологию за то, что они слишком привержены традиции не только Дюркгейма, но и М. Вебера.

${ }^{2}$ Fligstein, N. Architecture of Markets: An Economic Sociology of Twenty-First-Century Capitalist Societies. Princeton: Princeton University Press, 2001.

${ }^{3}$ Burawoy, M. Neoclassical Sociology: From the End of Communism to the End of Classes, American Journal of Sociology (January 2001). Vol. 106. No. 4. Рp. 1099-1121. М. Буравой рецензирует следующие книги: 
- Верно.

- А так ли это плохо - поддержсиать связь с трудами признанных классиков социиологии?

- С моей стороны, в данном случае это была не столько критика, сколько попытка категоризации, наименования [labeling]. И думаю, она была верной. В обеих книгах имеет место недооценка опыта массы людей в условиях переходной экономики. Старк и Бруст, Йел и Селеньи говорят, что не ставили специально подобных ограничений, но в результате они действительно не обращались к исследованию опыта большинства населения. А я лишь подчеркнул ту трансформацию, которая произошла в их собственных взглядах. И Старк, и Селеньи начинали с наблюдения государственного социализма снизу. А теперь они взглянули на новые формы капитализма сверху. Я же склонен считать, что есть и другие способы это сделать.

Конечно, традиции, идущие от Дюркгейма и Вебера, весьма ценны. Моя же критика Старка, Селеньи и их соавторов касалась только того, что они просмотрели. В частности, в их рассуждениях больше нет исследований классов, в то время как раньше все они анализировали классовые отношения. Эти авторы отказались от своего прошлого и, похоже, были раздражены, когда я на это указал ${ }^{4}$.

- Насколько я понимаю, Вы рассматриваете экономическую соичологию с некоторого расстояния, несколько извне. Могли бы Bbl назвать основные направления экономической сочиологии, как они Вам видятся? Например, проводите ли Вы четкую грань между традициями, идущими от Вебера и от Дюркгейма? Может быть, усматриваете какие-то другие размежевания?

- Думаю, в значительной мере это традиция, идущая от Дюркгейма. А поскольку речь идет о Дюркгейме, то мы возвращаемся к теории Т. Парсонса и началу 1950-х гг. Я имею в виду, что, например, работа Джона Мейера о неоинституционализме ${ }^{5}$ насквозь пропитана идеями Парсонса. В ней рассматриваются проблемы конвергенции, легитимности, общего консенсуса и ценностей. В экономической социологии очень заметно влияние Дюркгейма. А если обратиться к работам авторов, исследующих власть и властные отношения, заметно также и влияние Вебера - здесь Вы правы. Но, думаю, оно менее сильно. И я не возьмусь сказать точно, кого бы я отнес к этой категории.

- А сетевой подход? Он ведь отличается от обеих традиций?

Stark, David, and Laszlo Bruszt. Postsocialist Pathways: Transforming Politics and Property in East Central Europe. Cambridge: Cambridge University Press, 1998.

Eyal, G., Szelenyi, E. Townsley. Making Capitalism without Capitalists. L.: Verso, 1998.

${ }^{4}$ Авторские отклики на рецензию М.Буравого см.:

Eyal, G., Szelényi, I. and E.Townsley The Utopia of Postsocialist Theory and the Ironic View of History in Neoclassical Sociology, American Journal of Sociology (January 2001). Vol. 106. No. 4. Pp. 1121-1129.

David Stark And László Bruszt, One Way or Multiple Paths: For a Comparative Sociology of East European Capitalism, American Journal of Sociology (January 2001). Vol. 106. No. 4. Pp. 1129-1138.

${ }^{5}$ Meyer, J. and Rowan, B. Institutionalized Organizations: Formal Structure as Myth and Ceremony, in: Powell, W. and DiMaggio, P. (eds.). The New Institutionalism in Organizational Analysis. Chicago: University of Chicago Press, 1991. p. 41-62. 
- Признаться, я не понимаю всего этого ажиотажа по поводу сетей. Это эпифеномен, изучать сети для меня означает упустить реальность.

- Но, может быть, это иная реальность? Ведь Вы же не станете отрицать существование сетей?

- Да, конечно. Но дело в том, что сети, как мне кажется, нельзя объяснять через самих себя - это не теоретическая концепция. Факт нашей связи друг с другом требует какогото фундаментального объяснения, определенной теории хозяйства. И не думаю, что сети как таковые способны предоставить подобное объяснение.

Есть интересная книга А.Саксениан [AnnaLee Saxenian] о Силиконовой долине ${ }^{6}$ - о том, как она сформировалась и выросла, о важности сетевых связей между инженерами. Но, думаю, самая интересная работа в этой области - о самобытности и локальности [originality and locality], т.e. о локальных хозяйственных системах - выполнена географами. Пожалуй, наиболее известны здесь работы Майкла Сторпера [Michael Storper] $]^{7}$. Он пишет о сравнительных преимуществах локальности, ходе торговли, некоммерческих взаимозависимостях [untraded interdependences]. Эти ресурсы, имеющиеся на локальном уровне - существующие как данность и фиксируемые в пространстве, - обеспечивают определенное видение сравнительных преимуществ.

- Раз речь зашла о книгах и статьях, могли бы Вы назвать какие-то самые важные работы для экономической сочиологии за последние два-три-четыре года?

- Как я уже говорил, очень интересной мне кажется работа географов. Что касается моей области исследований, то меня интересует переход от государственного социализма к различным формам капитализма и новых рыночных хозяйств. Среди книг, которые широко обсуждались и которые показались мне интересными, я бы назвал те самые две книги, на которые я написал рецензию. Именно поэтому я так много внимания им и посвятил. Я имею в виду книги Старка и Бруста, во-первых, Йела, Селеньи и Таунсли, во-вторых. Думаю также, что книга Дэвида Вудрафа [David Woodruff] о России совершенно удивительна ${ }^{8}$.

Мне кажется также, что лучшие экономико-социологические работы опираются не только на идеи Дюркгейма и Вебера, но и на идеи Поланьи - я уже говорил об этом. Появляются новые исследования его подхода, к нему вновь возник интерес. И с моей точки зрения, это одна из самых важных и интересных особенностей нынешней экономической социологии.

- Хорошо ли Поланьи известен в Соединенных Штатах? Мне казалось, его связывают скорее с европейской сочиологической традицией. Правда, я знаю, что Фред Блок

${ }^{6}$ Saxenian, AnnaLee. Regional Advantage: Culture and Competition in Silicon Valley and Rout 128. Cambridge, Mass.: Harvard University Press, 1994.

${ }^{7}$ См., например: Storper, Michael. The Regional World: Territorial Development in a Global Economy. N.Y.: Guilford Press, 1997.

Storper, Michael and Robert Salais. Worlds of Production: The Action Frameworks of the Economy. Cambridge, Mass.: Harvard University Press, 1997.

Storper, Michael. Industrialization, Economic Development and the Regional Question in the Third World: From Import Substitution to Flexible Production. L.: Pion, 1991.

8 Woodruff, David. Money Unmade: Barter and the Fate of Russian Capitalism. Ithaca, N.Y.: Cornell University Press, 1999. 
недавно опубликовал новое издание «Великой трансформации» со своим предисловием и предисловием Дж. Стиглица9. Поланьи действительно столь влиятелен в США?

- Да, правильно, что Вы упомянули здесь Фреда. И еще я бы добавил работу Питера Эванса «Укорененная автономия» ${ }^{10}$. Ведь само понятие укорененности идет от Поланьи. И Грановеттер многое почерпнул у Поланьи. А о Селеньи вообще можно сказать, что Поланьи повлиял на всю его жизнь.

- Ну, он же венгр (как и Поланьи).

- Да, но Селеньи давно живет в Штатах. И идеи Поланьи оказали влияние на многих людей в США. Не думаю, что Дэвид Старк впрямую ссылается на Поланьи, но логика рассуждений у него порою схожая. Ведущие авторы почерпнули у него даже слишком много - тексты Поланьи являются классикой для каждого интересующегося экономической социологией. Потому что в них сочетаются, как я уже говорил, традиции, идущие от Дюркгейма, Вебера и Маркса. В них есть и элемент критики - он предлагает свое видение власти, свое видение отношений между государством, обществом и хозяйством. У него есть несколько оригинальных идей. Это весьма впечатляет. Думаю, здесь вы повсюду будете натыкаться на идеи Поланьи в той или иной форме.

- Да, это интересно. И наконец, последний вопрос: какие направления и темь исследований Bы считаете наиболее перспективными для экономической социологии и близких к ней дисциплин в ближайщем будущем?

- Несомненно, переход от государственного социализма к капитализму. Мне кажется, здесь сделано уже много интересного. И будет сделано еще больше. Можно упомянуть дискуссию в «Американском социологическом журнале» [American Journal of Sociology] по поводу переходного периода в Китае, а также в Центральной и Восточной Европе. Это была чрезвычайно интересная, продуктивная дискуссия. Ее вел Виктор Ни [Victor Nee], но участие принимали многие авторы.

- Вы говорили ранее, что в этой дискуссии почти не упоминалась Россия.

- Действительно. Примечательным в дискуссии было то, что никто не представлял пример России, который, с моей точки зрения, является примером провала реформ. Все говорили о примере Румынии или Болгарии. Но ведь провал-то случился не у них. Думаю, люди должны будут переосмыслить свои теории в свете российского примера (точнее, будет хорошо, если они это сделают). Однако анализ России, похоже, не интегрирован в социологию и особенно в экономическую социологию, как интегрирован в них, например, анализ Китая. Россия всегда стояла несколько особняком, рассматривалась, скорее, как исключение. Но мне кажется, социология только выиграла бы, если бы она интегрировала в сферу своих исследований этот крайний случай - со столь необычной, уникальной историей. Конечно, это не подразумевает ее инкорпорирование в некую общую теоретическую схему.

- Иными словами, Вы предложили бы своим студентам поехать в Россию?

- Я никогда ничего не предлагаю своим студентам. Это одна из особенностей Беркли ты здесь никому ничего не предлагаешь, даешь им делать то, что им хочется.

- Но Bы, по крайней мере, пытаетесь им что-то подсказывать? Не отправлять кудато, но вдохновлять на что-то?

\footnotetext{
${ }^{9}$ Polanyi, K. The Great Transformation. Boston: Beacon Press, 2001.

${ }^{10}$ Evans, Peter B. Embedded Autonomy. Berkeley: University of California Press, 1995.
} 
- Нет-нет, здесь так не принято. Это даже забавно.

\section{Библиография}

Burawoy, M. Neoclassical Sociology: From the End of Communism to the End of Classes, American Journal of Sociology (January 2001). Vol. 106. No. 4. Pp. 1099-1121.

Burawoy, M., et al. Global Ethnography: Forces, Connections, and Imaginations in a Postmodern World. Berkeley: University of California Press, 2000.

Burawoy, M., and K.Verdery (eds.) Uncertain Transition: Ethnographies of Change in the Postsocialist World. Lanham: Rowman \& Littlefield, 1999.

Burawoy, M. Critical sociology: A dialogue between two sciences, Contemporary Sociology (January 1998). Vol. 27, No. 1.

Burawoy, M., and J.Lukács. The Radiant Past: Ideology and Reality in Hungary's Road to Capitalism. Chicago: University of Chicago Press, 1992.

Burawoy, M., and P.Krotov. The Soviet Transition from Socialism to Capitalism: Worker Control and Economic Bargaining in the Wood Industry, American Sociological Review (February 1992). Vol. 57, No. 1.

Burawoy, M., et al. Ethnography Unbound: Power and Resistance in the Modern Metropolis. Berkeley: University of California Press, 1991.

Burawoy, M., and K.Hendley. Strategies of Adaptation: A Soviet Enterprise under Perestroika and Privatization. Bala Cynwyd, PA: WEFA Group, Special Projects, 1991.

Burawoy, M. Marxism as science: Historical Challenges and Theoretical Growth, American Sociological Review (December 1990). Vol. 55, No. 6.

Burawoy, M. The Politics of Production: Factory Regimes Under Capitalism and Socialism. L.: Verso; N.Y.: Schocken Books, 1985.

Burawoy, M. The Contours of Production Politics. Berlin: International Institute for Comparative Social Research, 1984.

Burawoy, M., and T. Skocpol (eds.) Marxist Inquiries: Studies of Labor, Class, and States. Chicago: University of Chicago Press, 1982.

Burawoy, M. Manufacturing Consent: Changes in the Labor Process Under Monopoly Capitalism. Chicago: University of Chicago Press, 1979.

Burawoy, M. Constraint and Manipulation in Industrial Conflict: A Comparison of Strikes Among Zambian Workers in a Clothing Factory and the Mining Industry. Lusaka: University of Zambia, Institute for African Studies, 1974.

Burawoy, M. The Colour of Class on the Copper Mines, From African Advancement to Zambianization. Manchester: Manchester University Press [for] the Institute for African Studies, University of Zambia, 1972. 


\section{ДЬЕРДЬ ЛЕНГЕЛЬ. 31 авГуста 2001 г. ${ }^{1}$}

Наша беседа состоялась в Хельсинки после последней сессии Исследовательской сети «Экономическая социология» на конференции Европейской социологической ассоциации. В большой комнате стало непривычно тихо. Дьердь (которого обычно называют либо «поанглийски» - Джорджи, либо «по-славянски» - Георгием), как всегда, говорил в своей спокойной флегматичной манере.

$*$

$*$

- Насколько я знаю, Вы считаете себя экономсочиологом. Когда это произошло, с какого момента и почему Вы стали называть себя именно так?

- Насколько я припоминаю, это случилось в конце 1970-х гг. Я в то время преподавал социологию в Университете экономических наук им. Карла Маркса в Будапеште. И меня особенно интересовало исследование хозяйственных институтов и экономических акторов. В то время мы находились под двойным неформальным давлением (не слишком сильным, но тем не менее). Мы должны были бороться за признание социологии как дисциплины в рамках университета и в научной среде в целом - это раз. И два - я должен был бороться за признание экономической социологии как особой области. Бывало, наш бывший ректор Рудольф Андорка [Rudolf Andorka] спрашивал меня: «А есть ли такая область знания - экономическая социология?» И я отвечал: «Да, конечно. Ведь ведутся исследования хозяйственных институтов, экономических акторов, экономического поведения». Прошло время, прежде чем он понял, что здесь существует более или менее сложившееся особое направление социологических исследований. А тем временем социология завоевала признание, мы разрабатывали новые курсы, стало возможным даже получить диплом по социологии. Так что это произошло в конце 1970-х - в 1980-х гг.

- А когда экономическая сочиология получила признание в Венгрии как особая область исследований? Я имею в виду, собственно под названием «экономическая социология»?

- Насколько я помню, примерно в середине 1980-х гг. мы образовали исследовательскую сеть экономсоциологов в рамках Венгерской социологической ассоциации.

Что еще важно применительно к нашему разговору: возможно, определение специальных областей в рамках той или иной дисциплины, выделение в ней различный полей играет роль в условиях нашей институциональной среды и присущих ей противоборств. Но для содержания и для развития дисциплины они не важны. Мне кажется, такие разделения порою могут вести к догматичному поведению. Я предпочитаю проблемноориентированные подходы [problem-oriented approaches], a не дисциплинарноориентированные [disciplinary-oriented approaches].

- С этим я в принципе согласен. Но все же для развития дисииплины важно, чтобы люди ощущали свою принадлежность именно к ней, связывали себя с ее именем, чтобы вокруг нее формировались институцчиональные образования.

- Да, это так. Но, насколько я помню, экономистами, работающими в области экономики труда [labor economics] и институциональной экономики, выполнено немало великолепных исследований - параллельно аналогичным разработкам в социологии. Кроме того, есть молодые исследователи в области социальной истории. В ряде случаев при решении исследовательских проблем их подходы не особенно отличаются от того,

${ }^{1}$ Перевод М.С. Добряковой. 
что мы делаем. И мы можем обмениваться с ними идеями, это гораздо более полезно и плодотворно, чем узко дисциплинарный подход.

- Хорошо. Вероятно, главный мой вопрос таков: какие методологические подходы и направления Bы назвали бы основными в современной экономической сочиологии, что составляет ее фундамент?

- Для меня методология - не самое главное. Самое главное - выявить социально значимые проблемы и найти их решение. Обнаружить проблему, выдвинуть правильную гипотезу, проверить ее - такова должна быть последовательность, как мне кажется. А что касается методов и подходов, то я полагаю, что существует, например, масса проблем с опросными методами: и недопонимание со стороны респондента, и вылавливание определенных данных некоторыми исследователями. Так что, я думаю, имеет смысл комбинировать хорошо обоснованные в теоретическом отношении гипотезы, методы опроса, глубинные интервью, невключенное повторяющееся наблюдение. Кроме того, быть может, не стоит забывать, что исследование архивных материалов не является исключительной прерогативой историков. Социологи также могут с ними работать. И метод устной истории [oral history] тоже может нам пригодиться. Так что в отношении методологии в узком смысле, я полагаю, стоит сочетать разные подходы.

- Да, я думаю, что в конечном счете в рамках любой дисциплинь можно использовать практически любые методы сбора данных.

- Конечно. И в последнее время, скажем, появился интерес к экспериментам с невключенным повторяющимся наблюдением за поведением экономических акторов. Такие эксперименты могут оказаться очень полезными при решении некоторых вопросов - например, при изучении поведения на рынке.

- Bы упомянули, что предпочитаете проблемно-ориентированный, а не дисциплинарный подход. А какие предметные области Вы назвали бы в качестве основных на настоящий момент?

- Которыми я интересуюсь и которые я считаю...?

- И которые важны для экономической сочиологии.

- Понятно. Для меня важнее всего сложнейшие загадки и серьезнейшие задачи, которые ставят перед нами перемены, вызванные посткоммунистической трансформацией. Интереснее и важнее всего для меня - понять потенциал действия экономических акторов, их способность и готовность справляться с социальными и экономическими проблемами. Этот потенциал определяется экономическими, социальными и культурными обстоятельствами акторов, позволяет им обрести более высокие жизненные шансы или избежать кризиса - на индивидуальном или семейном уровне, помогает преодолеть неопределенность и незащищенность социальной и экономической жизни. Это проблема, которая занимает меня прежде всего.

И отчасти связанная с ней проблема и одновременно новый вызов - распространение информационных технологий, их влияние как на хозяйственную деятельность, так и на повседневную жизнь. Это достойная задача для исследования. В нашем университете ведется серьезная работа в этом направлении, и я сам хотел бы попытаться взглянуть на потенциал действия экономических акторов под этом углом зрения. Например, умение работать с компьютером: помимо своего технического эффекта, является ли оно источником новых разграничений и разрывов в обществе, и насколько они серьезны? Не следует забывать, что средства массовой информации, включая телевидение, вызвали фундаментальные изменения в образе жизни людей, хотя они не сразу бросаются в глаза. Сейчас более двух часов в день в среднем мы проводим у телевизора. А некоторые возрастные группы проводят таким образом гораздо больше времени. А ведь он меняет 
отношение пожилых людей и к большой науке в целом, и ко многому другому. Это одна проблема.

Другая проблема связана с посткоммунистической трансформацией и изменениями в составе политических и хозяйственных элит, с изменениями их установок в этот период. От состава элит и их установок зависит, достигли ли мы той точки, когда процессы трансформации становятся необратимыми. Я полагаю, что это надо исследовать, поскольку если и существуют экономические и политические акторы, имеющие перед собой определенные цели, то в нашем обществе такими акторами являются именно элиты. Поэтому я и занимался изучением элит и планирую продолжать эту работу.

Есть и другие вопросы, которые ставят перед нами изменения в обществе. Назову лишь некоторые из них: мы наблюдаем рост числа экономически неактивного населения сейчас примерно половина взрослого населения экономически неактивна и не имеет постоянной работы. Какова структура этой части населения? Каковы их стратегии совладания с трудностями? Как они преодолевают состояние неопределенности и незащищенности? Структурированы ли они внутри себя? Вот основные вопросы, которые надо изучить.

Еще одна тенденция структурного свойства: в ходе трансформационных процессов сфера услуг в нашей стране заняла господствующее положение. И это также влияет на отношения занятости, процент безработных, структуру занятых. И отчасти связанное с этим, но концептуально иное явление - возникновение обслуживающего класса [service class]. Мы видим, что параллельно с классом предпринимателей возникает и класс служащих, состоящий из белых воротничков, работников умственного труда и менеджеров.

\section{- Имеется в виду понимание Голдторпа?}

- Да, это связано с идеями Голдторпа [John Goldthorpe]. И я думаю, это новое, современное явление, которое мы должны тщательно изучить. Мы должны попытаться выявить его социальные характеристики и последствия. В целом необходимо проанализировать возможные побочные эффекты возникающих ныне явлений, их непредвиденные последствия.

- Еще один вопрос: в последнее время ведутся разговоры о своего рода возрождении европейской экономической социологии. Bы согласны с этим - в Европе сейчас происходит что-то серьезное в этом отношении?

- Думаю - по крайней мере, таково мое впечатление от конференций и семинаров, - что сложилась критическая масса исследователей, изучающих эти аспекты социальной жизни, и, я полагаю, они существенно продвинулись вперед. Забавно (и, возможно, мы здесь не правы), но мы лучше знаем работы англосаксов, чем социологические работы, выполненные в соседних странах, - как говорил мой польский коллега Антонин Каминский. Но, насколько я знаю, в Центральной и Восточной Европе сейчас ведется интереснейшая работа.

- А какие книги или статьи по экономической сочиологии Bы назвали бы наиболее значимыми на сегодняшний день - если взять, допустим, последние два, три, может, четыре года, т.е. недавнее время?

- За последние пару лет, не уходя в середину девяностых?

- Да, и не уходя к классикам.

- Да, хотя время от времени их полезно перечитывать, и я регулярно это делаю - когда появляется время. Например, недавно я читал Раймона Арона. Это не новая, но обновляющая книга, совершенно точно. А из последнего, что я читал и мне понравилось, 
- это «Играя в одиночку» Роберта Патнэма ${ }^{2}$. Сначала он написал великолепную статью (коротенькую), а потом книгу - о падении роли социального капитала в Америке и связанных с этим проблемах. Она полезна также с точки зрения методов и подходов, которые он предлагает и предлагал в своих прошлых книгах. Мы всегда должны задавать себе вопрос: «И что? Каковы последствия?» И он построил свое исследование вокруг этого вопроса. Что-то обнаружил - какие могут быть последствия, какие различия с тем, что уже имеется. Так что это было интересно, действительно полезно и интересно.

Еще одна книга, которую я читал недавно, - это книга о мафии Диего Гамбетты ${ }^{3}$. Очень хорошо написана и аргументирована.

- Это книга о сищилийской мафии? Но если я не ошибаюсь, это было начало 1990-х г2.?

- Да, она вышла раньше, Вы, видимо, правы, просто я ее читал недавно.

- Вне всякого сомнения, она очень интересна.

- И еще, я не помню дату публикации, но недавно мы перевели статью Гамбетты и статью Патнэма по этому же вопросу. В данном отношении могут быть интересны и некоторые проблемы, связанные с восприятием людьми состояния неопределенности и незащищенности.

А что касается книг или статей, которые я выделил бы за последнее время, - тут у меня есть длинный-предлинный список. Некоторые мои венгерские коллеги написали ряд очень интересных работ. К сожалению, далеко не все можно прочесть на английском, не все доступно для широкой аудитории. Во-первых, это книга о венгерских предпринимателях, основанная главным образом на интервью. Она написана институциональным экономистом Михаем Локи. Великолепное, прекрасно написанное, очень полезное чтение. Еще одна книга - это работа моей коллеги Магдолы Левелаки. В ней описывается распад огромного предприятия и появление на его обломках малых предприятий. Часть этой книги переведена на английский под названием «Цветы зла» [Fleurs de mud] - аллюзия на поэму Бодлера. Левелаки написала также интересные работы о предпринимательской деятельности, отношениях занятости и безработице в Западной Венгрии. Прекрасные проблемно-ориентированные работы.

Еще одна работа, законченная только что и находящаяся в печати, - плод совместных усилий молодых исследователей под руководством Золтана Санто [Zoltán Szántó]. Используя различные методы - интервью, вторичный анализ материалов предприятия, сетевой анализ, - они детально исследовали возникновение и угасание предприятия. Они собираются опубликовать результаты этих исследований в книге. Я думаю, это может даже стать новой главой в истории венгерской экономической социологии.

- Раз речь зашла о венгерской экономической сочиологии, скажите, пожалуйста, каковы ее особенности? По сравнению, скажем, с восточно-европейскими или западноевропейскими странами?

- На этот вопрос нелегко ответить - необходимо принять во внимание работы стольких авторов, столько подходов. Однако, видимо, здесь есть своя традиция - и в этом нет сомнений. Она существует среди экономистов, институциональных экономистов и социологов - это традиция кейс-стади и так называемой социографии. Она сохранилась и поныне. Даже экономисты - по крайней мере, ряд венгерских экономистов, начиная с 1970-х гг. - с интересом ходили на предприятия, брали интервью, изучали реальные

${ }^{2}$ Putnam, Robert D. Bowling Alone: The Collapse and Revival of American Community. N.Y.: Simon \& Schuster, 2000.

${ }^{3}$ Gambetta, D. Sicilian Mafia. The Business of Private Protection. Cambridge, Mass.: Harvard University Press, 1993. 
процессы, сопоставляли результаты своих исследований с официальными данными. Так что, вероятно, это одно направление, причем достаточно сильное.

Другая особенность - продукт науки, сложившейся в начале XX столетия, в его первые десятилетия. Она состоит в понимании своего рода асинхронности в развитии институтов, структур и поведения, нестыковке между структурами и поведением акторов. Это понимание до сих пор питает критическую социологию, которую я более всего ценю в венгерской традиции.

- Прекрасно. И последний вопрос: какие темы и направления в экономической сочиологии, с Вашей точки зрения, наиболее перспективны для ближайших двух-трех-четырех лет?

- Да, одну вещь забыл упомянуть, когда говорил о книгах. Периодически - когда позволяет время - я хожу в Национальную библиотеку в отдел рукописей и читаю разные интересные работы. И прошлым летом я обнаружил любопытные фрагменты в рукописи Карла Поланьи. Они были написаны в 1959 и 1963 гг., т.е. незадолго до его смерти. Так вот, он называл себя экономсоциологом - я подумал, это может быть Вам интересно. А другой фрагмент - это неоконченная рецензия (вероятно, неопубликованная) на книгу Дж. Гэлбрейта ${ }^{4}$ о процветающем обществе, где он сравнивает подходы Гэлбрейта и Аристотеля, их представления о благополучном обществе. Гэлбрейт был амбициозен, и Поланьи тоже был амбициозен, он стремился найти путь к лучшему обществу. Мои амбиции в этом отношении не столь велики. И думаю, что более реалистично было бы выработать программу, которая позволит сделать общество не столько чуть более хорошим, сколько чуть менее плохим - это уже будет хорошо. Сейчас я размышляю об этом - чего никогда не делал прежде. Раньше меня раздражали все эти рассуждения об обществе будущего, однако недавно я начал задумываться о поиске чуть менее плохого общества.

- Немного футурологии...

- Да, и это как раз приводит нас к Вашему последнему вопросу о перспективных направлениях будущих исследований. Если опираться на последние исследования, думаю, здесь уже сложился некоторый консенсус относительно концептуальной схемы, и это большой шаг вперед. Ведь, как говорил Вебер, социологи редко обращаются к концепциям друг друга - так же, как нормальные люди не берут друг у друга зубную щетку. Здесь сделан заметный шаг вперед: сложился более или менее устойчивый консенсус относительно концептуальной схемы. И я вынужден признать, что это результат парадигмально-ориентированного подхода. С помощью этой концептуальной схемы можно выявлять некоторые вещи и делать определенные прогнозы. Несомненно, среди наиболее важных проблем - как справиться с фундаментальными структурными изменениями, вызванными информационными технологиями, глобализацией. Как адаптироваться к этим изменениям, какие стратегии оптимальны, какое сочетание внешних условий и личных усилий способно увеличить жизненные шансы индивида или, по крайней мере, не даст их ухудшить? Вероятно, это слишком общие рассуждения. Но предсказания никогда не являлись сильной стороной моей работы - да, думаю, и социологов вообще.

${ }^{4}$ Galbraith, John Kenneth. The affluent society. $2^{\text {nd }}$ ed., rev. Boston: Houghton Mifflin, 1969. См. также: Гэлбрейт Дж. К. Новое индустриальное общество. М.: Прогресс, 1969; Гэлбрейт Дж. К. Экономические теории и цели общества. М.: Прогресс, 1976. Прим. перев. 
- И я бы сказал, это не самое плохое качество сочиологии.

- Так что время от времени стоит пойти в архив или отдел рукописей, посмотреть старые рукописи, вообще изучить старые работы и книги. Это чрезвычайно интересно и освежает мысль. При этом я вовсе не советую молодым коллегам посвящать себя исключительно изучению работы других и скомпоновать свою книгу из десятка других книг. Совсем наоборот, я предлагаю выявить сто́ящую проблему, найти сто́ящие гипотезы и методы, которые позволят решать социально значимые проблемы. Наряду с этим, перечитывание классиков может быть поучительным и интересным занятием. Но, конечно, не стоит этого делать вместо [собственной работы].

- Спасибо.

\section{Библиография}

Lengyel, G., and Z. Rostoványi (eds.) The Small Transformation: Society, Economy, and Politics in Hungary and the New European Architecture. Budapest: Akadémiai Kiadó, 2001.

Higley, J., and G. Lengyel. Elites After State Socialism: Theories and Analysis. Lanham, Md.: Rowman \& Littlefield, 2000.

Lengyel, G. (ed.) The Transformation of East-European Economic Elites: Hungary, Yugoslavia and Bulgaria. Budapest: Budapest University of Economic Sciences, Center for Public Affairs Studies, 1996.

Kuczi, T., and G. Lengyel (eds.) The Spread of Entrepreneurship in Eastern-Europe: Survey Evidence on Entrepreneurial Inclination. Budapest: BUES Dept. of Sociology, 1995.

Lengyel, G., and Z. Szántó Zoltán (szerk.) A Gazdasági élet szociológiája : kézirat gyanánt. Budapest: Budapesti Közgazdaságtudományi Egyetem, Szociológia Tanszék, 1994.

Lengyel, G. (ed.) Hungarian Economy and Society During World War II. Boulder, Colo.: Social Science Monographs; Highland Lakes, N.J.: Atlantic Research and Publication; N.Y.: Columbia University Press, 1993.

Lengyel, G. A multipozícionális gazdasági elit a két világháború között: fejezetek egy történetszociológiai kutatásból. Budapest: ELTE Szociológiai és Szociálpolitikai Intézet, 1993.

Lengyel, G.(ed.). Education, Mobility, and Network of Leaders in a Planned Economy. Budapest: Karl Marx, University of Economic Sciences, Dept. of Sociology, 1987.

Lengyel, G. The Hungarian Business Elite in Historical Perspective: Career Patterns and Attitudes of the Economic Leaders in the Nineteenth and the First Half of the Twentieth Century. N.Y.: Institute on East Central Europe, Columbia University, 1987.

Lengyel, G. Gazdasági vezet"ok rekrutációja, képzettsége és karriermintái a tervgazdaságban. Budapest: Marx Károly Közgazdaságtudományi Egyetem Szociológia Tanszék, 1986. 


\section{Новые тексты}

$\boldsymbol{V R}$ Мы продолжаем публиковать главы новой книги Вадима Волкова о силовом предпринимательстве. В данном номере вашему вниманию будут представлены вторая и третья главы книги. Речь пойдет о теоретических подходах в политической экономии силы, а также об эволюции охранных услуг в России последнего десятилетия.

\section{СИЛОВОЕ ПРЕДПРИНИМАТЕЛЬСТВО В СОВРЕМЕННОЙ РОССИИ}

\section{Глава 2. К теории силового предпринимательства}

\section{Волков Вадим Викторович}

Европейский университет в Санкт-Петербурге

Email: Volkov@eu.spb.ru

Экономический обмен традиционно считается мирным и свободным видом деятельности, противоположным насилию и принуждению - так называемым «внеэкономическим методам» воздействия. В социальных науках принуждение ассоциируется с политической властью, институционально отделенной от хозяйственной сферы. Вопрос об экономической роли политических сообществ, если использовать терминологию Вебера, или о роли групп, владеющих средствами принуждения и стремящихся к установлению определенного порядка, до недавнего времени считался второстепенным. В экономической теории, за исключением работ нескольких исторически-ориентированных авторов, всегда существовало неявное предположение о том, что участники рыночного обмена находятся в ситуации равной безопасности; в ней редко уделялось внимание тому, какими способами, за счет каких издержек это условие достигается и что происходит, если условия равной безопасности нарушены. Группы и организации, ответственные за обеспечение безопасности, включая производство соответствующей информации, а также за ряд других функций, связанных с возможностью распоряжаться средствами насилия, редко попадали в поле зрения экономического анализа и оставались в ведении либо политической науки, либо правоведения (или даже криминологии). В данной главе делается попытка ввести такие организации в сферу социально-экономического анализа, сохранив при этом их социокультурную специфику. Для этого мы сначала рассмотрим позиции авторов, которые придавали первостепенное значение действиям владельцев средств принуждения и разрабатывали соответствующие теории. Затем будет предложено краткое теоретическое описание силового предпринимательства. В последующих главах мы наполним это понятие эмпирическим содержанием и тем самым постараемся объяснить ряд социально-экономических особенностей переходного периода в России.

\section{Политэкономия силы}

Различие между реальным насилием (т.е. непосредственным применением физической силы, сопровождающимся нанесением ущерба здоровью или собственности), и потенциальным насилием (т.е. есть угрозой силы, ставящей ее реальное применение в зависимость от дополнительных условий) вводит в игру широкий набор политико- 
экономических отношений. Важнейшим долгосрочным последствием наличия у какойлибо организации силового ресурса, т.е. последствием относительного преимущества в использовании физического насилия, является способность определять поведение других людей или организаций. К этим другим людям или организациям относятся, во-первых, другие владельцы силы, и, во-вторых, хозяйствующее, мирное население. В отношении других владельцев силы, выступающих в качестве потенциальной угрозы, силовой ресурс производит эффект сдерживания. Именно на эффекте сдерживания основано важнейшее общественное отношение, называемое «охраной», «защитой» или «обеспечением безопасности». Далее, силовой ресурс или ресурс физического принуждения может применяться для контроля за поведением тех, кто не владеет силовым ресурсом, - в частности, за поведением экономических субъектов, производящих конвенциональные блага и услуги. В этом случае силовой ресурс дает возможность управлять людьми, упорядочивать их поведение, обеспечивая предсказуемость действий и соблюдение правил или контрактов. Таким образом, наличие силового ресурса определяет две важнейшие формы ограничения действий других субъектов или управления их поведением - охрану [protection] и принуждение к исполнению [enforcement]. Они же естественным образом могут быть превращены в услуги, предоставляемые другим группам в обмен на деньги или иные ценности, которыми эти группы обладают.

Однако, говоря об охране и принуждении к исполнению (или правлении) как «услугах», мы вынуждены ставить кавычки и ни на секунду не забывать об условности такого определения. И охрана, и принуждение к исполнению являются качественно иным видом услуг, нежели обычные товары и услуги. Во-первых, они связаны не с каким-то конкретным видом хозяйственной деятельности, а с состоянием институциональной среды, в которой происходят другие виды деятельности. Охрана и принуждение к исполнению являются институциональными услугами (наряду с производством правил и информации), формирующими условия возможности той или иной упорядоченной деятельности. При низком уровне безопасности и предсказуемости (что в предельном случае одно и то же) любая другая деятельность будет затруднена. Во-вторых, приобретение таких услуг является обязательным, даже если их предложение - что случается далеко не всегда - не сопровождается прямой или косвенной угрозой. Услуга, основанная на принуждении, не может быть объектом абсолютно свободного выбора, в противном случае само ее качество будет поставлено под сомнение. В-третьих, охрана и принуждение к исполнению содержат встроенную тенденцию к монополизации. Иными словами, они предполагают однозначный раздел сфер влияния (раздел рынков) между владельцами средств насилия или установление субординации, исключающей разнонаправленные воздействия.

\section{Дань и охранная рента}

Экономический историк Фредерик Лэйн считал охрану действительной услугой, а спрос на нее - объективной необходимостью. При этом он предложил разделить предприятия на два типа: 1) те, которые производят охрану и называются правительствами, и 2) те, которые производят материальные блага или услуги и при этом платят правительствам за охрану. Плата за охрану, полагал Лэйн, может принимать форму не только непосредственных платежей за конкретные услуги по обеспечению безопасности, но и существовать в превращенных формах, включая налоги, тарифы, подарки, взятки в пользу тех, кто контролирует средства насилия. Независимо от формы, эти платежи составляли важнейший параметр политической экономии раннего капитализма, влияя на 
издержки и создавая разнообразные предпринимательские возможности ${ }^{1}$. Представив отношения по поводу охраны и безопасности как обмен между поставщиком и покупателем, Лэйн оказался первым обществоведом, предпринявшим попытку систематического анализа этих отношений с экономической точки зрения.

Доходы от использования силы принимают две основные формы: охранная дань и охранная рента. Предприятия, производившие охранные услуги - города-государства, княжества, королевства и другие политические организации, - занимались сбором охранной дани, составлявшей важнейший источник их дохода. Чистый доход военной элиты складывался из совокупных сборов с подданного мирного населения минус затраты на содержание войска или ведение войны. Правительство получало нечто наподобие монопольного дохода, который во многих случаях инвестировался обратно в экономику. Даже если данный доход тратился исключительно на предметы роскоши для правящей элиты, это стимулировало производство новых видов продукции и не являлось полностью непродуктивным использованием ресурсов, утверждает Лэйн.

Однако это был не единственный доход, который приносила торговля охранными услугами. В определенных условиях покупатели не только несут бремя охранных издержек, но и сами могут получать доход от подобных услуг. Это происходит в случае умелой политики охранного предприятия (правительства). Лэйн ввел понятие охранной ренты - специфического дохода, получаемого купцами или другими производителями каких-либо мирных услуг за счет возможности покупать охрану по более низким ценам, чем у конкурентов, и тем самым снижать издержки и реализовывать это преимущество на рынке. Охранная рента являлась, по сути, разновидностью дифференциальной ренты, получение которой зависело от эффективности, активности и ценовой политики предприятия, контролировавшего организованное насилие и поставлявшего охранные услуги. При этом как охранные предприятия, так и торговые группы были вовлечены в сложные конкурентные отношения, нацеленные на получение экономических преимуществ путем использования реального и потенциального насилия, - когда для поддержания высокого уровня риска коммерческой деятельности и нанесения ущерба конкурентам привлекались пираты, разбойники, частные и правительственные армии, использовались иные средства.

Наиболее яркий исторический пример устойчивого, коммерчески успешного взаимодействия производителей охраны и торговых предпринимателей являла собой Венеция, военная аристократия которой активно способствовала, прежде всего за счет умелого использования военного флота, увеличению совокупного богатства республики ${ }^{2}$. Например, в конце XI в. Венеция получила от Византии хартию, согласно которой еe купцы наделялись правом беспошлинной торговли, что давало им колоссальные конкурентные преимущества. Этими привилегиями они обязаны венецианскому правительству, предоставившему военный флот для поддержки византийского императора в войне против нормандского короля Сицилии, а затем и для других военных кампаний. Благодаря такой политике военных купцы получали охранную ренту, ибо их охранные издержки в Византии, в отличие от издержек конкурентов, были равны нулю (в то время как конкуренты должны были платить пошлины, которые Лэйн причисляет к категории охранных издержек). На примере Венеции Лэйн попытался показать - в духе меркантилистского подхода к вопросу об

1 Lane, F. Profits from Power: Readings in Protection Rent and Violence-controlling Enterprises. Albany: State University of New York Press, 1979. P. 2.

${ }^{2}$ Lane, F. Venice, A Maritime Republic. Baltimore: The John Hopkins University Press, 1973. 
источниках богатства, - что охранная рента как реализация в международной торговле преимуществ, полученных в результате умелого использования силы, может стать важным источником экономического роста отдельно взятых государств. В эпоху раннего капитализма, пишет Лэйн, охранные ренты «были более важным источником доходов, чем превосходство в промышленных технологиях или промышленной организации» ${ }^{3}$.

\section{Трансакиионнье издержки}

На самом деле аргумент, выдвинутый Лэйном в пользу экономической продуктивности правительств или других организаций, владеющих средствами насилия, может быть принят, только если предположить, что перераспределение ресурсов от слабых стран в пользу более сильных является естественным и неизбежным процессом, и продуктивность государства измеряется его выигрышем в условиях игры с нулевой суммой. Поэтому модели Лэйна можно противопоставить аргумент, известный еще во времена Адама Смита: создание торговых монополий, перераспределение богатств или заключение торговых соглашений с помощью силы не является экономически оправданным, поскольку ведет к неоптимальному использованию ресурсов, отклоняя последние от наиболее эффективного их помещения, которое может подсказать лишь свободный рынок. Но модель, предложенная Лэйном, - это не единственный способ решить проблему экономической роли владельцев средств насилия. Дуглас Норт предложил альтернативную теорию, в рамках которой рассматривается прежде всего способность правительств определять правила игры и принуждать экономических субъектов им следовать и, тем самым, формировать условия, способствующие экономическому росту или, наоборот, тормозящие его.

Что нам может сказать неоинституциональная теория об экономической роли силовых структур, в том числе государств? Неполнота информации о свойствах обмениваемых благ, о других участниках обмена (или ее несимметричное распределение среди участников экономической деятельности), а также необходимость контролировать соблюдение договорных обязательств вызывают появление трансакционных издержек. Иными словами, значительные ресурсы инвестируются в создание общей системы мер и весов, обеспечение безопасности, формулирование правил (законодательства) и контроля за их исполнением для того, чтобы упорядоченный экономический обмен стал возможен. Правила, регулирующие обмен, образуют институты, благодаря которым поддерживается порядок и уменьшается степень неопределенности в поведении контрагентов. При этом любая система экономического обмена, от локальной бартерной экономики до международной торговли, предполагает существование некоторых механизмов контроля за выполнением правил. В локальных экономиках плотная сеть социальных связей и моральные нормы принуждают людей к выполнению контрактных обязательств. Трансакционные издержки в такой системе будут ничтожны, но и территориальные масштабы обмена будут чрезвычайно малы. С ростом специализации и развитием торговли на дальние расстояния отношения обмена выходили за пределы локальных сообществ и полагались на безличные отношения или отношения в малознакомой местности или с малознакомыми партнерами. Здесь сразу возрастает значимость информации и появляются трудности с принуждением к исполнению обязательств. Трансакционные издержки начинают влиять на издержки производства. Тогда участники обмена стремятся образовывать свои ассоциации, гильдии, сети; они

${ }^{3}$ Lane, F. Venice and History: The Collected Papers of Frederick C. Lane. Baltimore: The John Hopkins Press. P. 412-422. 
обмениваются заложниками, обзаводятся охранными отрядами или даже частными армиями, начинают активно взаимодействовать с правительствами. Создание этих институтов, предназначенных обеспечивать безопасность и принуждать к исполнению обязательств, предполагает растущие затраты. Основной аргумент Норта заключается в том, что торговля и другая экономическая деятельность будут развиваться лишь тогда, когда выгоды от нее будут больше, чем трансакционные издержки, связанные с созданием институциональной среды.

Способы принуждения к исполнению [enforcement] различаются по своим затратам и эффективности, то есть требуют различного количества ресурсов и покрывают различные по протяженности экономические пространства. В некоторых случаях экономические субъекты способны создать эффективные механизмы контроля, не сдерживающие развитие торговли. К примеру, неформальные ассоциации и частные охранные организации способны решать многие институциональные проблемы и способствовать расширению торговли, но их потенциал ограничен. Наиболее эффективное решение, по мнению Норта, - это универсальный посредник, способный вводить единые правила, законы, единицы измерения и контролировать их применение. Благодаря экономии на масштабах, деятельность такой опосредующей инстанции будет сравнительно дешевой, а применение единых правил и стандартов позволит расширить пространство предсказуемого и правилосообразного поведения. Очевидно, что этим посредником является современное государство, которое на пространстве своей юрисдикции обеспечивает охрану граждан, непредвзятое разрешение споров и исполнение обязательств. «Государство продает совокупность услуг, которые мы назовем охраной и юстицией, в целях извлечения дохода. Поскольку в предоставлении этих услуг задействована экономия на масштабах, в результате появления организации, специализирующейся на этих услугах, совокупный доход общества будет выше, чем если бы каждый индивид сам защищал свою собственность» ${ }^{4}$. Более эффективная охрана и юстиция, таким образом, создают возможности для экономического роста.

Тем не менее, во многих случаях организации, обладающие преимуществом в использовании силы и соответственно имеющие возможности определять и контролировать права собственности, не в состоянии создать эффективные институты. Напротив, они склонны к чрезмерному и экономически непродуктивному изъятию и присвоению ресурсов экономического общества - до тех пор, пока конкуренция или организованный интерес последнего не поставят жесткие пределы удовлетворению текущих потребностей государства и не переориентируют его на учет долгосрочных интересов экономического развития. Неоинституциональная теория, однако, не предлагает какого-либо объяснения того, почему в истории удавалось ограничивать интересы государства и изменять его политику. В последующих главах мы вернемся к проблеме выбора силовыми структурами определенной экономической политики. В данный момент важно выделить общую для Лэйна и Норта мысль, имеющую также непосредственное отношение к данному исследованию. Отношения между организациями, владеющими средствами насилия, и их политика по отношению к экономическим субъектам, для которых они выступают в качестве источников безопасности и контроля за соблюдением правил, решающим образом влияют на экономические показатели той области, в которой каждый из них - будь то государство или частная, достаточно автономная охранная организация, - обладает монополией.

\footnotetext{
${ }^{4}$ North, D. Structure and Change in Economic History, N.Y.: Norton, 1981. P. 23.
} 


\section{Определение и типология}

Экономический аспект деятельности силовых структур, т.е. способы или методы, с помощью которых они зарабатывают деньги, можно обозначить термином «силовое предпринимательство». Производный термин, силовые предприниматели [violent entrepreneurs], ранее упоминался авторами, изучавшими сицилийскую мафию, но не получил какого-либо теоретического развития ${ }^{5}$. В данной работе предлагается систематическое применение этого термина для исследования и концептуального объединения ряда явлений, родство которых не всегда очевидно. Понятие «силовое предпринимательство» будет применяться более широко, чем это делали упомянутые авторы, то есть не только для обозначения деятельности преступных групп, но также для описания действий законных и неформальных (не описанных в каких-либо законах) организаций или даже государств.

Силовое предпринимательство можно определить как совокупность организационных решений и способов действия, применяемых для конвертащии организованной силь (угроз или насилия) в деньги или другие рыночныле блага на постоянной основе. Если потребительские товары составляют основной ресурс торгового предпринимательства, деньги - финансового предпринимательства, информация - информационного, и так далее, то силовое предпринимательство конституируется социально организованным насилием, потенциальным или реальным. Информационный ресурс для деятельности силовых структур не менее важен, однако пока мы ограничимся лишь самым простым определением и сосредоточимся на главном. Силовое предпринимательство - это средство извлечения и увеличения частных доходов групп, владеющих и распоряжающихся средствами насилия посредством установившихся отношений обмена с другими группами, владеющими другими ресурсами. Основную единицу силового предпринимательства мы будем называть, следуя обыденному словоупотреблению, «силовой структурой» или другими сходными понятиями - такими, как «организация, владеющая средствами насилия» (или средствами физического принуждения) и «охранное предприятие». Специалистов, занятых в этой области, мы будем называть иногда в соответствии с обыденным словоупотреблением (бандиты, сотрудники охранных предприятий, работники милиции, органов государственной безопасности и т.д.), а иногда - имея в виду сходные аспекты их деятельности как частных лиц обобщенно: «силовые предприниматели». Позже, в связи с рассмотрением основного вида силового предпринимательства, «силового партнерства», будет введен еще один термин - «силовой партнер».

Применительно к российскому контексту 1990-х гг. мы предлагаем следующую простейшую классификацию силовых структур и соответственно силовых предпринимателей. Они делятся на законные и незаконные (преступные), а также на государственные и частные. В итоге мы получаем четыре основных типа силовых структур (см. таблицу 1): незаконные частные (организованные преступные группировки); законные частные (частные охранные предприятия и службы безопасности); незаконные государственные (неформальные группы сотрудников милиции и госбезопасности, так называемые милицейские и «комитетовские» «крыши»); и законные государственные (органы правопорядка и госбезопасности, действующие только по должностной инструкции). Несомненно, в реальной жизни границы могут исчезать, образуя смешанные типы.

${ }^{5}$ Blok, Anton. The Mafia of A Sicilian Village: A Study of Violent Peasant Entrepreneurs, Oxford: Basil Blackwell, 1974; Gambetta, Diego. The Sicilian Mafia: The Business of Private Protection, Cambridge, Mass.: Harvard University Press, 1993. P. 77. 
Таблица 1. Типология силовых предпринимателей

\begin{tabular}{|l|l|l|}
\cline { 2 - 3 } \multicolumn{1}{c|}{} & \multicolumn{1}{|c|}{ Незаконные } & \multicolumn{1}{c|}{ Законные } \\
\hline Частные & $\begin{array}{l}\text { Организованные } \\
\text { преступные группировки } \\
\text { и сообщества }\end{array}$ & $\begin{array}{l}\text { Частные охранные } \\
\text { предприятия и службы } \\
\text { безопасности }\end{array}$ \\
\hline Государственные & $\begin{array}{l}\text { Неформальные группы } \\
\text { работников милиции и } \\
\text { органов госбезопасности }\end{array}$ & $\begin{array}{l}\text { Государственные служащие, } \\
\text { действующие только по } \\
\text { инструкции }\end{array}$ \\
\hline
\end{tabular}

Грабитель не подходит под определение силового предпринимателя, а стационарный бандит или местный князь, наоборот, является таковым, постольку поскольку он стремится к установлению длительных налоговых отношений с подданными (т.е. теми, с кого собирается дань) и предоставляет им определенные услуги, которые призваны оправдывать поборы. Превосходство в применении силы является необходимым условием силового предпринимательства, но оно не образует его содержания. Конвертация организованной силы в постоянный доход включает набор методов, которые приобретают форму отношений обмена определенных услуг на деньги или по крайней мере деклараций о якобы предоставляемых услугах. Эти услуги, как правило, включают физическую охрану, защиту прав собственности, разрешение споров (арбитраж), принуждение к исполнению и в некоторых случаях создание с помощью силы конкурентных преимуществ своим клиентам. Мы предлагаем объединить эти услуги в три группы, в результате чего получим три основных вида силового предпринимательства: физическая охрана; силовое партнерство; силовое посредничество. В следующей главе будет подробно описан каждый вид, а также связи между ними.

Доходы силовых предпринимателей принимают форму дани или налога (на прибыль, с оборота), собираемого регулярно и в соответствии с более или менее постоянной ставкой - как бы в оплату регулярных благ или услуг, которые владельцы средств насилия предоставляют клиентам или обитателям некоторой территории. Отсюда очевидно, что силовое предпринимательство предполагает высокую степень монополизации использования силы внутри сферы, являющейся объектом правления и налогообложения. Вмешательство других субъектов охраны или налогообложения ставит эту деятельность под вопрос до окончательного выяснения отношений между конкурентами и раздела сфер деятельности - как правило, с использованием силы или угроз. Поэтому владельцы средств принуждения склонны мыслить в терминах «территорий» и «сфер влияния» и проявляют болезненную чувствительность к вопросам границ. За пределами монополизированной сферы, наоборот, находится пространство, где царят неопределенность, угрозы и конкуренция, что служит обоснованием деятельности силовых предпринимателей для их клиентов. Таким образом, монополия силы и соответственно иерархия внутри определенной сферы и неограниченная конкуренция, то есть анархия, за ее пределами являются логическими условиями силового предпринимательства. Забегая вперед, скажем, что именно это различие состояний является структурным условием возможности силового предпринимательства.

Наконец, необходимо подчеркнуть, что силовое предпринимательство является частной деятельностью. Это значит, что оно предполагает относительную свободу при принятии 
тактических и стратегических решений относительно использования силы, автономию от других источников принуждения и возможность извлечения частного дохода, напрямую зависящего от эффективности действий владельца силового ресурса. Таким образом, если некая силовая структура (в предельном случае - государственный аппарат насилия в целом) подчинена более высокой инстанции или находится под общественным контролем, то ее возможности вести силовое предпринимательство существенно ограничены (в сфере международной политики в случае суверенных государств такие ограничения очень слабы). И наоборот: когда государственные служащие, имеющие доступ к соответствующим ресурсам, выходят из-под контроля вышестоящих инстанций и получают возможность извлекать дополнительный доход от распоряжения этими ресурсами как частные лица, они становятся силовыми предпринимателями.

\section{Глава 3. Силовое предпринимательство в России 1990-х}

Мы начнем рассмотрение силового предпринимательства с его первой и элементарной формы - предоставления охранных услуг, включая так называемый «охранный рэкет» [protection racket], т. е. отношений, связанных с предложением физической охраны в ситуации как объективной, так и искусственно созданной угрозы. Затем мы перейдем к анализу более сложных форм силового предпринимательства - силового партнерства и силового посредничества, когда производитель разнообразных институциональных услуг не является прямым источником угрозы и не имеет непосредственного контроля за уровнем рисков, возникающих в экономической деятельности.

\section{От вымогательства к охранным услугам}

Вымогательство является основным сюжетом популярного романа И. Ильфа и Е. Петрова «Золотой теленок», напечатанного в 1931 г. Желающий разбогатеть аферист Остап Бендер ищет и находит подпольного миллионера Корейко, «золотого теленка», и всячески принуждает его расстаться со своим богатством. Боясь репрессий со стороны советского государства и будучи при этом неспособным обеспечить свою безопасность и отвадить вымогателей, подпольный миллионер вынужден в конце концов выложить свои миллионы Остапу. В советский период «золотые телята» были серыми и невзрачными на вид, изо всех сил стремясь казаться обыкновенными советскими гражданами. Поэтому основная интрига романа состоит в поиске и идентификации «серенького» подпольного миллионера и применении к нему изощренных (и комичных) методов психологического воздействия.

Масштабы теневой экономики, как известно, значительно выросли к 1980-м гг. Она включала множество видов деятельности, использовавших как внутренние недостатки государственного социализма, так и любые подворачивавшиеся возможности личного обогащения: производство неучтенной продукции, подпольное производство алкоголя, спекуляция дефицитными товарами, мошенничество, антикварный бизнес, подпольный игорный бизнес и т.п. Популяция «золотых телят» стремительно росла, но наследники Бендера заметно отставали, поскольку идентификация с виду «сереньких» потенциальных жертв оставалась большой проблемой. Хуже того, во многих случаях подпольные «миллионеры» обзаводились связями с коррумпированными партийными и советскими служащими, предоставлявшими им неформальное прикрытие. 
Существовавшие в то время группы вымогателей состояли в основном из уголовников как, например, банда Монгола, терроризировавшая московских «теневиков» в 1969-72 гг. Банда была создана Геннадием Карьковым по кличке «Монгол» в 1969 г., после того, как он отсидел три года за хищение государственной собственности. Другим членом банды был Вячеслав Иваньков по кличке «Япончик», который впоследствии станет одним из наиболее влиятельных лидеров преступного мира и будет осужден за вымогательство в США в 1996 г. Тогда, в начале 1970-х гг., банда занималась поиском людей с «сомнительными» доходами и оказывала на них жестокое давление с целью заставить жертву делиться частью этих доходов. В отличие от «рафинированных» вымогателей из сатирического романа, реальные персонажи попросту заколачивали свою жертву в гроб и предлагали прокатиться в «последний путь» до кладбища. Банда Монгола была арестована в 1972 г., и ее лидер получил 15 лет ${ }^{6}$. Для самих «подпольных миллионеров» обладание богатством было опасным и потому тщательно скрываемым признаком: в случае его обнаружения государством или вымогателями проблемы были неизбежны, с той разницей, что вымогатели постараются конфисковать собственность, а государство конфискует еще и свободу.

Ввиду комплексной природы этого вида преступления, а также его ограниченной распространенности в России в прошлом, определение вымогательства долго оставалось предметом дискуссии. Основная трудность состояла в том, чтобы отделить вымогательство от ограбления и шантажа. Одни юристы подчеркивали отложенный характер угрозы как основную характеристику вымогательства; другие предлагали рассматривать права собственности, а не конкретные вещи или деньги как определяющий предмет вымогательства; третьи настаивали на том, что предметом этого преступного действия является человеческая свобода как таковая. В результате эволюции юридического определения вымогательства все эти нюансы вошли в уголовные кодексы 1960 г. и 1994 г. как подвиды широко толкуемого типа преступления ${ }^{7}$. Таким образом, вымогательство было определено как действия, нацеленные на присвоение чьей-либо собственности или прав собственности под угрозой насилия или нанесения вреда собственности или ее владельцу, равно как и под угрозой распространения порочащей данное лицо информации. В новой редакции Уголовного кодекса, принятой в 1994 г., максимальный срок лишения свободы за вымогательство был увеличен до 15 лет $^{8}$.

В юридической практике доказать факт вымогательства довольно трудно, поскольку угрозы часто носят скрытый или непрямой характер. Жертва может не испытывать явного давления, особенно если вымогатели ведут себя достаточно дружелюбно, не прибегая к откровенно враждебным действиям. Трудности в определении состава вымогательства возникают и в случае, если угрозы исходят от лица, не являющегося получателем вымогаемой собственности, или если собственность переводится на другое лицо, явным образом не связанное с источником угроз. Именно в силу того, что в отличие от ограбления вымогательство предполагает косвенное принуждение и влияет на будущее, а не на непосредственное поведение жертвы, оно представляет значительные трудности для строгого правового определения. Все это делает «мягкие» формы вымогательства достаточно привлекательным бизнесом, обладающим высокими

\footnotetext{
${ }^{6}$ Трабарин А. Воры в законе и авторитеты. М.: Эксимо-пресс, 2000. С. 20-40.

${ }^{7}$ Сафонов В. Организованное вымогательство: Уголовно-правовой и криминологический анализ. СПб: Знание, 2000. С. 10-27.

${ }^{8}$ Верин В. Преступления в сфере экономики. М.: Дело, 1999. С. 47-49.
} 
шансами избежать уголовно-правовых санкций. В.Сафонов утверждает, что организованное вымогательство характеризуется особо высокой латентностью, которая в середине 1990-х гг. в некоторых регионах России достигала 70\% ${ }^{9}$.

\section{Охранный рэкет}

Вымогательство представляет собой некое действие, квалифицируемое как уголовное преступление, в то время как охранный рэкет - это институционализированные отношения. В российской уголовной практике обвинения обычно выносятся по конкретным фактам, т. е. после того, как отношения между преступником и жертвой удается разбить на отдельные эпизоды, содержащие состав преступления и подлежащие доказательству. Социологическая задача, следовательно, противоположна юридической и состоит в том, чтобы установить, каким образом отдельные действия индивидов и групп, направленные на вымогательство тех или иных благ, превращаются в устойчивую систему отношений.

Многие кооператоры и частные предприниматели периода перестройки начинали в сфере теневой экономики, другие, напротив, не имели к ней никакого отношения. Однако для значительной части населения все они выглядели подозрительно. То, чем многие из них занимались, еще вчера клеймилось как спекуляция, незаконная торговля и т.п. С самого начала кооперативный сектор возник как бы в особой институциональной среде, характеризовавшейся относительно низким уровнем безопасности и недостаточной легитимностью в глазах общества. Одним из последствий остаточных советских моральных установок была стигматизация новых предпринимателей. Слово «кооператор» имело неоднозначные оттенки, а термин «частник» был откровенно презрительным. Опросы общественного мнения зафиксировали сначала смешанное, а потом и все более негативное отношение к кооператорам, которых считали весьма деятельными, но при этом нечестными или даже откровенно преступными элементами ${ }^{10}$.

C началом экономической либерализации и кооперативного движения идентификация потенциальных объектов вымогательства перестала быть проблемой. При этом потенциальными жертвами вымогателей были уже легитимные, a не теневые предприниматели, теоретически имевшие право на защиту и полную правовую поддержку со стороны государства, но редко получавшие их на практике. Специальная статистика насилия над предпринимателями отсутствует: они далеко не каждый раз обращались с письменным заявлением в милицию, а если и обращались, то эта статистика растворялась в показателях других видов преступлений, не отражавших их экономическую специфику (хулиганство, нанесение телесных повреждений и т.п.) ${ }^{11}$. Однако печальный опыт предпринимателей первой волны хорошо запечатлелся в памяти

${ }^{9}$ Сафонов В. Организованное вымогательство: Уголовно-правовой и криминологический анализ. СПб: Знание, 2000. С. 157.

${ }^{10}$ Если в 1989 г. 45\% общесоюзной выборки выражали положительное отношение и $30 \%$ отрицательное отношение к деятельности кооперативов, в 1990 г. это соотношение составило 30 и 42\% соответственно. См.: Radaev, V. Practicing and Potential Entrepreneurs in Russia, International Journal of Sociology, 1997. Vol. 27, No 3. P. 25.

${ }^{11}$ По мнению экспертов, угон автотранспорта заявляется в $80 \%$ случаев; хищение другой собственности - в 40\%; нанесение телесных повреждений - в 25\%; вымогательство только в 10\%. См.: Организованная преступность / Под ред. А. Долговой. М.: Криминологическая ассоциация, 1998. С. 36. 
участников (включая самих вымогателей) и многократно воспроизводился в воспоминаниях, художественной литературе и кино. Паяльник и утюг стали основными инструментами вымогателей новой волны и навязчивыми символами кооперативного движения, а предложение вырыть собственную могилу - стандартным методом начинающего рэкетира. Из воспоминаний рэкетира:

«...Конечно, прибегали мы и к жестким формам наезда. Подъезжаем, говорим: “Давай, плати, лох”. И он платил. А те, кто не соглашался, подвергались нашему прессингу. Благо учебные пособия у нас были хорошие - те же художественные кинофильмы. Были популярны паяльник и батареи с наручниками, которыми мы пристегивали клиента. Случалось, вывозили его в лес или закрывали в подвале. После небольшой обработки “влегкую” с избиением клиенты соглашались платить». ${ }^{12}$

Но даже после того, как предприниматель шел на уступки и выплачивал требуемую сумму, рэкетиры не исчезали. Наоборот, прецедент выплат закладывал основу дальнейших действий, и выплаты производились уже регулярно. Мы не будем здесь приводить разнообразные «страшные» истории запугиваний, физических воздействий и убийств предпринимателей с целью вымогательства, предполагая, что читатель прямо или косвенно знаком с этой страницей истории отечественного капитализма. Рассказы о грубых наездах рэкетиров стали неотъемлемой частью атмосферы, в которой развивалось частное предпринимательство после начала перестройки. Иными словами, предпринимательский риск был осознан довольно быстро, и далеко ходить за примерами было не нужно - они приходили сами.

Если вымогательство является вполне строгим уголовно-правовым понятием, за которым стоит конкретный эпизод, то охранный рэкет - это уже некоторая устойчивая система социально-экономических отношений, выходящая за рамки взаимодействия двух субъектов и сама оказывающая влияние на поведение участников. Прежде чем приступить к анализу структуры отношений, лежащей в основе охранного рэкета, напомним, как он осуществлялся в повседневной жизни. В своей элементарной форме охранный рэкет имел место на городских рынках, характеризовавшихся высокой плотностью торговли и простой пространственной организацией. Если рынок не был монополизирован одной преступной группировкой, он делился на некоторые сегменты, которые рэкетиры охраняли друг от друга. Каждый рэкетир представлял собой конкретную угрозу частным торговцам и одновременно за определенную плату оказывал некоторым из них охранные услуги. При необходимости представители группировок или бригад подтверждали факт «охраны» - иными словами, факт того, что те или иные торговые места платят охранную дань именно им. По сути, это была не столько активная защита, сколько конвенциональное воздержание от насильственных действий, дающее возможность продолжения свободной торговли и оправдывающее получение дани (хотя в случае нарушения конвенции и попыток «получить» с «чужих» коммерсантов возникали конфликты). С точки зрения коммерсанта, выплаты рэкетирам приобретали форму налога, дающего право на начало и продолжение торговли. Не обладая собственным силовым ресурсом для обеспечения своей экономической деятельности, коммерсанты были вынуждены платить за него тем, у кого он был. По свидетельствам респондентов, довольно быстро заработала и обратная логика: бандиты «ставили» «своих» коммерсантов, давая им подъемные деньги и соответственно обеспечивая охрану от посягательств себе подобных.

\footnotetext{
${ }^{12}$ Карышев В. Записки бандитского адвоката. М: Центрполиграф, 1998. С. 34.
} 
Как только открывался какой-нибудь частный магазин или кафе, в него тут же наведывались мобильные бригады, предлагавшие охранные услуги. Все различные мягкие или жесткие сценарии таких визитов можно свести к одному: выяснить, «кому этот барыга платит», иными словами, обеспечен ли данный экономический субъект охраной. Если директор не мог дать вразумительный ответ на этот вопрос (т. е. назвать группировку или имя (кличку) одного их лидеров), автоматически следовало предложение о регулярной выплате предприятием охранной дани. Это означало, что название группировки, первой обнаружившей «свободную точку», и ее контактный телефон будут называться при появлении других таких же лиц, интересующихся вопросами безопасности. Понятно, что для таких случаев была предусмотрена стандартная процедура проверки того, действительно ли названная группа получает дань и имеет ли она на это право (этот важнейший момент будет потом рассмотрен отдельно). В случае, если информация не подтверждалась, коммерсанта ждали санкции (примерно как за дачу ложных показаний) в виде физической расправы или дополнительных выплат за попытку обмана. Размер охранной дани начинался с 300-400 американских долларов в месяц и по мере развития «охраняемого» предприятия возрастал до 20-30\% его прибыли.

Не все отрасли хозяйственной деятельности представляли одинаковый интерес для охранного рэкета. Наибольшей привлекательностью обладали малые предприятия, особенно в сфере услуг, оптовой и розничной торговли, с низкими инвестиционными потребностями, быстрым и значительным наличным оборотом и относительно простой технико-экономической схемой деятельности. По данным опроса предприятий розничной торговли, проведенного в Москве, Смоленске и Ульяновске в 1996 г., выплаты дани частным охранным структурам стали рутинным явлением. Более $40 \%$ предпринимателей признали факт частых контактов с рэкетом, считая при этом рэкет менее проблематичным явлением, чем произвол чиновников и налоговых органов. Исследование показало также, что большинство владельцев торговых предприятий воспринимало частные охранные структуры как заменитель государственных органов охраны правопорядка и отчасти - судебных органов ${ }^{13}$. Если вначале экономические субъекты были, в основном, жертвами вымогательства и рассматривались как таковые со стороны ОПГ, то позже обе стороны часто устанавливали рабочие отношения, считавшиеся, как показывают интервью, взаимовыгодными в данных экономических условиях. Предприниматели часто видели в рэкетирах поставщиков действительных услуг и даже требовали их, когда возникали соответствующие обстоятельства. Из интервью с московским бизнесменом:

Bonpoc: Были ли случаи, когда вас посещали с предложениями охраны, или просто грубые «наезды» с целью вымогательства?

Oтвет: Такие ситуации были. Вот как с одним из наших генеральных директоров, фактически он являлся нашим соучредителем. И он очень любил хвастаться. Как только у него появилась новая квартира, новая иномарка, сразу же эти ребята начали требовать деньги. Но у нас (опять же, дело случая - была такая передряга) угнали новый КАМАЗ. И мы сказали: «Хорошо, вы будете у нас крыша, если вы найдете нашу машину». Естественно, они ничего не нашли, к нам опять пришли, мы им то же самое высказали, и на этом все дело притихло. [...]

Boпрос: Отношения с рэкетом выгодны для бизнесменов?

${ }^{13}$ Frye, T. and E. Zhuravskaya, Rackets, Regulation, and the Rule of Law, Journal of Law, Economics, and Organization (October 2000). Vol. 16. P. 478-502. 
Oтвет: Я считаю, что это, в принципе, нормальный вариант. Опять же, если бы ребята, которые пришли к нам, помогли вернуть машину, то тогда бы с ними стоило работать. А так как они только умеют просить деньги, как только что-то серьезное, сразу в сторону... [...] Тот же серьезный рэкет не будет заниматься мелким вымогательством, это им слишком дорого встает. Незачем доводить людей до крайности, потому что каждый из нас в любой момент пойдет сразу же в РУБОП, сразу же начнется официальное расследование. [20]

\section{Охрана как реальная услуга}

Немногие рэкетиры хотят кого-либо охранять. Изначально у них нет такого намерения, но на практике они вынуждены это делать. Иными словами, охрана является структурным результатом взаимодействия участников, приоритетным по отношению к их субъективным намерениям. Все, чего хочет рэкетир, - это получать деньги, чем больше, тем лучше. На жаргоне слово «получать» или «получалово», собственно, и означает охранный рэкет в целом. Каждый рэкетир в отдельности предпочел бы просто получать, но, будучи частью системы со множеством взаимодействующих рэкетиров, он вынужден охранять или предоставлять другие подобные услуги. Трудно понять природу охранных отношений, рассматривая лишь одного, отдельно взятого рэкетира: его действия всегда будут представляться как простое вымогательство. Однако на самом деле концепция охраны (или защиты) предполагает множественность владельцев силы, каждый из которых одновременно может выступать и как угроза, и как источник защиты. Известный теоретик международной политики Кеннет Уолтц, говоря о межгосударственных отношениях, сформулировал это так: средства, с помощью которых одни государства угрожают другим, являются, в самой своей основе, средствами обеспечения собственной безопасности ${ }^{14}$.

Отдельный случай охраны будет всегда похож на вымогательство - ситуацию, когда источник угрозы и источник безопасности совпадают, но могут быть разделены за определенную плату. Но если мы введем в анализ параметр времени и учтем существование других владельцев средств насилия, то защита (охрана, безопасность) приобретет форму реальной услуги, предоставляемой клиенту: участники не смогут усомниться в факте защиты. В этом случае роль угрозы играет кто-то другой, и владелец средств насилия имеет возможность предлагать охрану как некоторую услугу, в которой клиент объективно нуждается. То есть возникают основания предложить обмен, а не требовать односторонний выкуп. Пытаясь прояснить различие между вымогательством и действительной охраной в контексте политики государств, социолог Чарлз Тилли указывает, хотя и косвенно, на то, что это различие предполагает значительный элемент субъективной интерпретации:

«Какой именно образ вызывает у нас слово охрана [protection], зависит в основном от нашей оценки реальности и угрозы, а также того, до какой степени угроза является внешней. Индивид, производящий одновременно и угрозу, и защиту от нее, является рэкетиром. Тот, кто предоставляет требуемую защиту, но имеет очень слабый контроль за появлением угроз, может быть определен как

${ }^{14}$ В оригинале фраза звучит так: «The means of security for one state are, in their very existence, the means by which other states are threatened». Waltz, K. Theory of International Politics. Reading, Mass.: Addison-Wesley Pub. Co., 1979. 
легитимный защитник, особенно если цена его услуг не выше, чем у конкурентов» ${ }^{15}$.

На самом деле, эта не слишком приятная дилемма не описывает две различные ситуации, а возникает в едином поле, созданном взаимодействием множества владельцев средств насилия. Каждый владелец средств насилия может выступать одновременно как защитник для своих клиентов и как источник угрозы - потенциальной и анонимной или, наоборот, вполне конкретной - для тех, кто не является его клиентом. Группа владельцев средств насилия является и тем, и другим одновременно. Поэтому «фокус», в результате которого появляется целая совокупность специфических социально-экономических отношений, называемых «охрана» или «защита», состоит во внутреннем - и неизбежном - разделении группы владельцев средств насилия на враждебные (конкурирующие) стороны так, что каждый из них является конкретным и действительным защитником от некоторой потенциальной угрозы, в существование которой он также вносит свой вклад. Вымогательство неизбежно превращается в предоставление действительных охранных услуг в условиях множественности угроз, что характерно для сферы, в которой отсутствует монополия на применение силы. Т.е. речь идет об определенной структурной ситуации, а не о «добрых» или «злых» намерениях конкретных владельцев силы и их субъективном выборе. В последующих главах мы вернемся к рассмотрению того, как эта структурная ситуация порождает определенные практики силового предпринимательства, в частности, «разводки».

Вернемся к ситуации, в которой оказались российские предприниматели первой волны. Даже исправно платившие охранную дань не были гарантированно защищены от сюрпризов. Пропорции распределения дохода от активов того или иного предприятия между бизнесменом и бандитами основывались на некоторых конвенциях, создававших видимость справедливости, но фактически устанавливались бандитами (особенно на более ранних этапах развития рынка). Хотя испытание паяльником или утюгом, копание собственной могилы и подобный опыт уже не угрожали бизнесмену, находившемуся под защитой частной силовой структуры (в противном случае подобные действия рассматривались бы как направленные против этой структуры, а не против бизнесмена), постепенная экспроприация активов путем произвольного повышения ставки «налога», а иногда и убийства «своих» бизнесменов для завладения их активами оставалась распространенной практикой. Она называлась «дербанить коммерсанта» и считалась естественной, ибо рэкетиры воспринимали охраняемых коммерсантов как свою собственность. Претензии на охрану содержали неявное утверждение права собственности. При решении коммерческих споров члены ОПГ часто называли бизнесменов, плативших им охранную дань, «наш барыга» или «наш коммерсант», подразумевая тем самым свою ответственность за его поведение и право распоряжаться его собственностью.

Однако суть этих элементарных неформальных отношений собственности лежит не в отношениях между бандитами и коммерсантами, а прежде всего в отношениях между самими владельцами средств насилия (ОПГ или другими силовыми структурами). По сути, право собственности по отношению к активам бизнесмена обеспечивалось наличием силового ресурса и реализовывалось в отстаивании силовой структурой права на получение охранной дани перед другими претендентами. Поэтому время от времени силовые структуры вынуждены были защищать своих клиентов от себе подобных. Но

${ }^{15}$ Tilly, C. War Making and State Making as Organized Crime, in: Evans P., Rueschemeyer D., and T. Skocpol (eds.). Bringing The State Back In. Cambridge: Cambridge University Press, 1986. P. 173. 
делали они это прежде всего для того, чтобы сохранить за собой право на получение части дохода охраняемого предприятия, т. е. чтобы исключить других «получателей». Эта ситуация наглядно иллюстрирует то, почему права собственности иногда определяются как отношения исключения ${ }^{16}$. Впоследствии среди ОПГ и других силовых структур происходил процесс внутренней дифференциации в зависимости от их политики по отношению к охраняемым предприятиям: некоторые стремились максимизировать размер получаемого дохода и часто разоряли «своих» коммерсантов; другие действовали, ориентируясь на более долгосрочную перспективу, и перераспределяли права собственности так, чтобы обеспечивать интересы своих клиентов и получать долгосрочный доход за счет коммерческого успеха последних. В последнем случае функции силовой структуры сдвигались в сторону создания конкурентных преимуществ «своим» коммерсантам. Затем, с развитием акционерных форм собственности, силовые структуры (через специально учрежденные компании) становились формальными совладельцами некогда охраняемых ими предприятий (подробнее об этом речь пойдет в главе 6).

\section{Силовое партнерство}

Этот термин упомянул в интервью один из респондентов, когда описывал деятельность своей силовой структуры и ее роль по отношению к другим бизнесменам. Респондент рассказывал о поиске коммерческих возможностей для своих клиентов, обеспечении гарантий под поставки товаров, заключении неформальных соглашений или использовании угроз для того, чтобы заставить кого-либо выплачивать полагающуюся сумму. «Мы что-то вроде силовых партнеров», - обобщил авторитет. Я сказал, что это интересный аналитический термин, который я хотел бы использовать в социологическом исследовании. Мой собеседник не возражал.

Итак, под силовым партнерством мы будем понимать ряд бизнес-функций силовых структур - функций, основанных на умелом коммерческом использовании организованной силы и информации, обеспечивающих благоприятные институциональные условия для экономической деятельности предприятий клиентов. Институциональные условия включают: безопасность, информационную поддержку, обеспечение прав собственности, в том числе контроль за соблюдением контрактных обязательств и возвратом долгов, а также разрешение коммерческих споров.

Распространение рэкета в кооперативном секторе в конце 1980-х гг. оставалось экономически периферийным явлением. Основные производственные активы находились в руках государства, административная система работала, а фискальный кризис был еще впереди. Переход от охранного рэкета или просто физической охраны к более сложным и специализированным функциям силового партнерства произошел примерно в 1992-95 гг. в контексте значительного расширения частного сектора. К этому времени преступные группировки накопили значительный объем силовых и финансовых ресурсов, необходимых для более активного участия в экономических процессах переходного периода. С одной стороны, силовые предприниматели жестко навязывали клиентам свои услуги, и во многих случаях у бизнесменов не было иного выхода, кроме как работать с преступными группировками. При этом преступные группировки

16 «Суть отношений собственности состоит в праве исключать, и организация, имеющая сравнительные преимущества в насилии, имеет возможность определять и обеспечивать (enforce) права собственности». North, D. Structure and Change in Economic History, N.Y.: Norton, 1981. P. 21. 
успешно создавали и повышали спрос на свои услуги. Но, с другой стороны, объективный спрос на силовых партнеров был тоже достаточно высок, и бизнесмены часто сами обращались к представителям организованной преступности для разрешения конфликтов или обеспечения гарантий. Обратившись однажды к бандитам, многие предприниматели не вольны были самостоятельно прекратить это сотрудничество и попадали под постоянный контроль тех или иных группировок. Таким образом, инициатива, в целом, принадлежала силовым предпринимателям. Но без объективного спроса институт силового партнерства не получил бы такого широкого развития. Поэтому сначала мы рассмотрим практику создания искусственного спроса, а потом обратимся к анализу независимых факторов, поддерживавших высокий уровень спроса на силовых партнеров.

\section{Искусственный спрос}

Тактика жесткого давления и физического устрашения, практиковавшаяся преступными группировками, а также постоянные сообщения в СМИ, усиливавшие ощущение опасности и повышенного риска, привели к силовым предпринимателям множество клиентов. Искусственно создаваемые трансакционные проблемы также способствовали усилению потребности в силовых партнерах. Эту тактику можно проиллюстрировать следующим примером. Семья Петренко (фамилия изменена) приехала в Петербург с Украины в поисках работы. Через некоторое время они начали работать с представителями «комаровской» группировки, учредив торговую фирму, предлагавшую оптовые поставки ходовых продуктов по низким ценам. Для поставки продуктов фирма требовала предоплату. Собрав таким образом определенное количество денег, в основном с представителей отдаленных регионов, фирма попросту исчезала, а через некоторое время появлялась вновь под другим именем, снова рекламируя оптовые поставки. Этот нехитрый, но очень распространенный бизнес-трюк известен как «кидок». Если обманутые покупатели все же начинали заниматься активными поисками и приезжали в Петербург, пытаясь вернуть свои деньги, «комаровские» доходчиво объясняли им бесперспективность этого занятия. Но когда в целях возврата денег из Сибири от имени одного коммерсанта приехали два вора в законе, то «комаровские» вернули деньги и неустойку. Очевидно, что сибирские силовые партнеры взяли себе значительные комиссионные за возврат предоплаченной суммы [22].

На этом примере видно, что силовые партнеры с обеих сторон (и оказывавшие прикрытие мошенникам, и помогавшие вернуть деньги) оставались в выигрыше. . При этом, помимо явного выигрыша, они косвенно стимулировали спрос на силовых партнеров, повышая риск коммерческой деятельности для тех, у кого их не было. Практически все преступные группировки в начале 1990-х гг. практиковали как «кидки», так и возврат денег работавших с ними (точнее, части денег). Постепенно и неизбежно эта деятельность рационализировалась, все больше приобретая черты превентивного уменьшения риска «кидков». Прежде чем переводить деньги, силовые партнеры старались раздобыть информацию о потенциальных продавцах или покупателях и получить гарантии у их силовых партнеров. «Кидать» бизнесменов («лохов») было вполне легитимной практикой, но обманывать своих, т. е. бандитов, было чревато серьезным риском и не поощрялось принятыми в данном сообществе нормами. Похожая тактика создания фирм-однодневок активно применялась в сфере кредитных отношений, когда преступные группировки искали возможности получить кредит через подставных бизнесменов с целью его последующего присвоения. В этом случае единственными способами страховки были либо полная информация о получателе кредита, либо 
гарантии силового партнера в отношении возврата этого кредита. Нетрудно увидеть, что такая система увеличивала потери или выводила из бизнеса тех, кто не платил и соответственно не пользовался прикрытием силовых партнеров. В какой-то момент спрос на силовых партнеров становился самоподдерживающимся.

На языке силовых предпринимателей искусственное стимулирование спроса часто обозначалось фразой «создать проблему», что также предполагало последующую возможность ее разрешения с получением коммерческой выгоды. Неправильно было бы предполагать, что силовые предприниматели намеренно давали друг другу заработать ( хотя, несмотря на высокий уровень конфликтности в криминальной среде, тактическое сотрудничество не исключалось). На первоначальном этапе система взаимозависимости работала так, что конфликты между силовыми структурами, вызывавшие определенные потери, поддерживали высокий уровень риска на экономическом рынке. Тем самым конфликты обеспечивали стабильный доход владельцам силы за счет экономического класса (хотя некоторым представителям этого класса сотрудничество с силовыми партнерами было в определенных смыслах выгодно).

\section{Трансакционные проблемы}

Не менее серьезны были действительные проблемы, возникавшие в результате непродуманной экономической политики и быстрой приватизации. Политика «шоковой терапии» включала снятие административного контроля за ценообразованием, либерализацию торговли, в том числе в сфере экспортно-импортных операций, и приватизацию малых и средних предприятий. Быстрота проведения была, по крайней мере в начале, одним из важнейших принципов реформ. По замыслу, она должна была предотвратить чрезмерное участие в процессе приватизации бывшей советской номенклатуры и криминального мира. Но во многом результаты оказались противоположными.

Сотни тысяч предприятий были приватизированы в 1992-1996 гг., новых предприятий было учреждено не меньше. Большинство крупных и средних предприятий перешли в собственность трудовых коллективов и директоров; доля внешних владельцев поначалу была сравнительно невелика ${ }^{17}$. Мне не встречалось убедительных свидетельств того, что на начальных этапах преступные группировки становились собственниками предприятий или даже стремились к этому. Но зато многое говорит о том, что, поскольку существовавшие на тот момент правовые институты были неэффективны и доступ к ним предполагал высокие издержки, преступные группировки и другие силовые структуры принимали активное участие в решении трансакционных проблем, опосредуя отношения между новыми собственниками.

К трансакционным проблемам можно отнести неспособность выполнить контрактные обязательства (поставить или оплатить товар, вернуть кредит и т.п.), дефицит наличных денег для ведения экономической деятельности, проблемы безопасной доставки товаров и подобные трудности. Если не считать сознательного мошенничества, то трансакционные проблемы порождались как субъективными факторами (недостаточным опытом и квалификацией в бизнесе, низким уровнем ответственности и оппортунизмом), так и объективными причинами, вызванными ограничением денежной массы и разрушением хозяйственных связей. Опросы предпринимателей, проводившиеся в 1990-

${ }^{17}$ Cм.: Blasi, J., Kroumova, M., and D.Kruse. Kremlin Capitalism: The Privatisation of the Russian Economy. Ithaca: Cornell University Press, 1997. 
е гг., устойчиво показывали, что низкая контрактная дисциплина и низкий уровень надежности партнеров воспринимались как наиболее острые проблемы ${ }^{18}$. Оппортунизм был обычным явлением на товарных биржах: клиенты или брокеры могли выставлять свои товары одновременно на нескольких биржах, выбирать наиболее выгодные условия, а потом «прокидывать» по другим заключенным контрактам ${ }^{19}$. Субъективные просчеты и нехватка наличности только преумножали задолженности предприятий, а политика правительства усугубляла кризис неплатежей ${ }^{20}$. Директор, чье предприятие в августе 1994 г. задолжало 7 млрд. руб. и которому, в свою очередь, были должны 8 млрд., так охарактеризовал ситуацию: «Все предприятия теперь в долгах, мы должны нашим поставщикам, нам должны наши заказчики, которым тоже должны. Все друг другу должны и никто не платит, и все ждут бог знает каких гарантий» ${ }^{21}$.

Появление тысяч новых банков и других финансовых учреждений в начале девяностых сопровождалось ускоренным ростом невозвращенных кредитов. Согласно некоторым оценкам, общая сумма невозвращенных кредитов составила 3 трлн. 609 млрд. руб. (1,64 млрд. долл.) в начале 1994 г.; около 8 трлн. (1,75 млрд. долл.) в начале 1995 г. ${ }^{22}$ и 44 трлн. (7,9 млрд. долл.) к концу 1996 г. $^{23}$

Российские и зарубежные исследователи выделили несколько возможных способов решения трансакционных проблем, практиковавшихся на российских рынках: использование имеющихся социальных связей [relational contracting], неформальные урегулирования, государственный арбитраж, частные арбитражные комиссии и использование частных силовых структур. Исследователи сходятся в том, что в российской деловой практике участники в большой степени полагаются на имеющиеся (родственные, дружеские и т.п.) связи и неформальные методы, в значительной степени - на частные силовые структуры, и относительно мало пользуются государственными судебными инстанциями (хотя этот показатель начал возрастать во второй половине 1990-х гг. $)^{24}$. Вместе с тем, различные группы предпринимателей прибегают к

18 Большинство бизнесменов, опрошенных на Первом всероссийском конгрессе предпринимателей, главной проблемой назвали низкую надежность партнеров / Информационный бюллетень КСБР, 1995, № 1. С. 32-35. См. также Радаев В. Формирование новых российских рынков: трансакционные издержки, формы контроля и деловая этика. М.: Центр политических технологий, 1998. С. 116-127

${ }^{19}$ Frye, T. Caveat Emptor: Institutions, Contracts, and Commodity exchanges in Russia, in: Weimer, Dave (ed.) Institutional Design, Institutions, and Commodity Exchange in Russia. Boston: Kluwer Academic Publishers, 1995. P. 45.

${ }^{20}$ См.: Woodruff, D., Money Unmade: Barter and The Fate of Russian Capitalism. Ithaca: Cornell University Press, 1999.

21 Цит. По: Hertz, N. Russian Business Relationships in The Wake of Reform. Oxford: Macmillan, 1996. P. 101.

22 Оценки, представленные на семинаре начальников служб безопасности российских банков в Москве в январе 1995 г. // БДИ, 1995, № 2. С. 15.

23 Глинкина С. Особенности теневой экономики в России // Независимая газета, 18 марта 1998 г.

24 Согласно данным 1994 г. 20\% опрошенных предпринимателей предпочитали пользоваться государственными правоохранительными и судебными инстанциями, $15 \%$ предпочитали обращаться к бандитам и частным охранным агентствам, $11 \%$ полагались на собственные силы, 14\% использовали другие (не уточнялось, какие) 
различным методам решения трансакционных проблем - в зависимости от сферы деятельности, формы собственности, времени начала активной деятельности и других факторов, поэтому неизбежные «перекосы» в выборках ведут к различным результатам. Предприниматели, которые несут высокие расходы на безопасность, менее склонны пользоваться государственными судебными инстанциями в случае конфликтов. Они также демонстрируют более высокую готовность к применению силы, когда сталкиваются с недобросовестным поведением контрагентов ${ }^{25}$.

На точность результатов, полученных в результате опросов предпринимателей и директоров предприятий, также влияет ряд факторов, не подконтрольных исследователям. По моему опыту, предприниматели, работающие с преступными группировками, склонны отказываться от сотрудничества с исследователями, они еще менее охотно идут на контакт или предоставляют информацию, чем сами члены группировок. Соответственно такие предприниматели будут мало представлены в выборках. Далее, аналитические различия между основными способами решения трансакционных проблем трудно провести на эмпирическом уровне. Неформальные соглашения и встречи, которые фигурируют в исследованиях как способы решения трансакционных проблем, на деле часто предполагают реальное или виртуальное присутствие силовых партнеров. Даже фраза: «давай решим все мирно, не привлекая бандитов», в определенном контексте может быть угрозой, подчеркивающей возможность обращения к силовым партнерам. Наконец, некоторые респонденты сообщали о все более распространенной практике, когда имущественный спор решался в судебном порядке, но принуждением к его исполнению занимались частные лица, т. е. бандиты. Имея на руках письменное решение арбитражного суда и занимаясь взысканием в частном порядке, они рисковали попасть лишь под статью «самоуправство» - довольно мягкую по сравнению со статьями о вымогательстве или грабеже.

\section{Низкая эффективность судебной системы и высокая цуена доступа к ней}

Одной из причин широкого распространения института силового партнерства стало игнорирование значительной частью предпринимателей государственной судебной и правоохранительной системы. Истоки такого отношения лежат в запутанности существующих законов и подзаконных актов, больших сроках рассмотрения дел в судах и слабости исполнительной системы. Приватизация собственности проходила в контексте недостаточно специфицированных прав собственности, неполноты корпоративного законодательства и отсутствия механизмов контроля. Эту ситуацию часто называли «правовым вакуумом». С 1992 г. основная нагрузка по рассмотрению имущественных споров была возложена на арбитражные суды. Согласно принятым

методы разрешения споров, а 40\% воздержались от ответа. См. Тамбовцев $B$. Государство и переходная экономика: пределы управляемости. М.: Теис, 1997. С. 76. Опрос, проведенный в 1996-97 гг., показал, что 11\% предпринимателей были готовы применять силовые методы для решения спорных вопросов, 42\% испытывали эти методы на себе, а 53\% признали регулярные расходы на безопасность, причем более трети из них оценили эти расходы как значительные. Радаев $B$. Формирование новых российских рынков: трансакционные издержки, формы контроля и деловая этика. М.: Центр политических технологий, 1998. С. 129, 174, 185.

${ }^{25}$ Radaev, V. Corruption and Violence in Russian Business in the Late 1990s, in: Ledeneva, A. and M. Kurkchiyan, Economic Crime in Russia. L.: Kluwer, 2000. P. 79-81. 
нормам они должны были рассматривать дела в течение двух месяцев со дня принятия к рассмотрению. На практике, однако, большая часть дел в 1993-97 гг. рассматривались с превышением установленных сроков (в среднем три-четыре месяца, при этом тысячи дел тянулись более одного года) $)^{26}$.

Но даже вынесение судебных решений еще не означало окончательного торжества справедливости, поскольку их исполнение представляло собой еще большую трудность. Формально этим должны заниматься судебные исполнители или приставы, но распространенные приемы саботажа делали их практически бессильными. Судебные органы не обязаны заниматься розыском должника или его имущества, если его нет по номинальному адресу, и дополнительных ресурсов на это приставам не выделяется. Проблема поиска, таким образом, перекладывается на заинтересованную сторону, которая должна решать ее в частном порядке. Кроме того, предвидя судебные осложнения, компании-должники часто переводят свои активы на имя других компаний. Подобные действия могут предпринимать и частные лица, переписывая собственность на родственников, жен, любовниц и т.д. Это объясняет, например, неожиданно высокую долю женщин (более 35\%) среди номинальных владельцев наиболее дорогого и престижного автомобиля Мерседес-600 в Петербурге ${ }^{27}$. В случае, если судебный исполнитель не обнаружит какой-либо собственности или ценностей у должника, единственный возможный выход - наложить на должника обязательство выплачивать половину зарплаты в пользу кредитора, что, разумеется, во многих случаях не является приемлемым решением проблемы. Согласно данным, опубликованным министром юстиции в апреле 1995 г., в то время удавалось исполнить в среднем лишь половину судебных решений. Он также отметил опасную тенденцию снижения количества подаваемых в суды заявлений, касавшихся разрешения имущественных споров, и объяснил это тем, что граждане предпочитают внесудебные способы ${ }^{28}$. По другим источникам, показатель доли исполненных судебных решений за 1997 г. еще ниже около $32 \%{ }^{29}$.

Низкая эффективность работы судебных органов и низкая результативность официальных способов исполнения решений были не единственными факторами, способствовавшими тому, что многие граждане или хозяйствующие субъекты игнорировали государственную судебную систему. К ним следует добавить чрезмерно высокие издержки легальной экономической деятельности, т. е. высокую цену доступа к государственной судебной системе, которая подталкивала к поиску альтернативных (теневых) судебных механизмов ${ }^{30}$. Согласно различным источникам, на протяжении

26 В 1993 г. количество дел, рассмотренных с превышением нормативных сроков, составило более 236 тыс. (всего за год было рассмотрено 275 тыс.); в 1994 г. - 254 тыс. (из 285 тыс.), из которых более 16 тыс. дел находились в судах более года. Эта тенденция сохранялась по крайней мере до 1997 г. См. Скобликов П. Взыскание долгов и криминал. М.: Юрист, 1999. С. 45.

27 Данные собраны совместно с Агентством журналистских исследований. Автор также благодарит Елену Богданову (Европейский университет) за помощь в анализе данных.

${ }^{28}$ Правда, 19 июля 1995 г.

${ }^{29}$ См. Скобликов П. Взыскание долгов и криминал. М.: Юрист, 1999. С . 30.

30 Об издержках легальной экономической деятельности см.: Панеях Э. Издержки легальной экономической деятельности и налоговое поведение российских предпринимателей / Конкуренция за налогоплательщика: исследования по фискальной социологии. Под. ред. В.Волкова. М.: МОНФ, 2000. С. 26-48 . 
1990-х гг. доля теневой экономики колебалась в пределах от 20 до 45\% ВВП ${ }^{31}$. Среди основных причин роста теневой экономики исследователи приводят высокий уровень налогов и запутанную систему их взимания, нестабильность бюрократических норм, коррупцию и непредсказуемость исполнительной власти, особенно на местах ${ }^{32}$. При этом необходимо оговориться, что лишь относительно небольшая доля теневой экономики является содержательно криминальной, т. е. имеющей дело с запрещенными законом товарами и услугами. Содержание значительных сегментов «теневой», «серой» или «неформальной» экономики вполне законно. Именно уход (полный или частичный) от отношений с государственными органами регистрации и налогообложения или нарушение установленных этими органами правил впоследствии делает государственную судебную систему недоступной для многих экономических субъектов. Отсутствие налогового кодекса и ситуация постоянно меняющихся правил и ставок, к тому же произвольно трактуемых налоговыми органами на местах, привели к тому, что в конце 1990х гг. фактическое налогообложение могло превышать 80\% прибыли, не считая неформальных поборов. «Мы готовы работать с рэкетом, потому что он берет $10 \%$. Государство берет $90 \%$ в виде налогов и еще больше в виде разного рода поборов и штрафов», ${ }^{33}$ - это высказывание предпринимателя из Омска хотя и содержит некоторые искажения (бандиты берут до $30 \%$, а иногда и больше; от государства можно откупиться меньшими потерями), тем не менее хорошо отражает установку определенной части мелкого и среднего бизнеса.

Наконец, кроме низкой эффективности и запретительной цены доступа, ограниченное пользование государственной судебной системой было обусловлено и некоторыми более «тонкими» социокультурными факторами. Так, согласно одному исследованию деловых отношений в России, «суды не используются часто потому, что они, по мнению участников, разрушают человеческие отношения» ${ }^{34}$. Для определенной части управленцев человеческие (дружеские) отношения рассматриваются как важный актив, и судебное разбирательство может действительно представляться чем-то неэтичным. Судебное разбирательство деперсонифицирует отношения и тем самым потенциально снижает значимость личностного компонента. По мнению некоторых исследователей, это часто является более важным соображением, нежели эффективность или цена судебного разбирательства. «Сдвиг в сторону частных арбитражных инстанций», пишет Кэтрин Хэндли, - «является более логичным направлением развития, чем сдвиг в

${ }^{31}$ МВД дает следующие пропорции доли теневой экономики в ВВП по годам: 1991 г. $10-11 \% ; 1993$ г. - 27\%; 1994 г. - 39\%; $1995-45 \%$; 1996 г. - 46\%. Госкомстат приводит более низкие проценты: 1992-94 гг. - 9-10\%; 1995 г. - 20\%; 1996 г. - 23\%. См.: Косалс Л. Теневая экономика как особенность российского капитализма // Bonpocbl экономики, 1998, № 10. С. 59.

${ }^{32}$ См., например: Исправников В., Куприянов В. Теневая экономика в России. М.: Фонд перспективных технологий, 1997; Неформальный сектор в российской экономике / Под ред. Т. Долгопятовой. М.: ИСАРП, 1998.

33 Цит. по: Чирикова А. Женщина во главе фирмы. М.: Институт социологии РАН, 1998. C. $179-180$.

${ }^{34}$ Hertz N., Russian Business Relationships in the Wake of Reform. Oxford: Macmillan, 1996. P. 111. 
сторону верховенства закона, поскольку здесь генеральный директор не должен отдавать свою власть безличным силам». ${ }^{35}$

\section{Силовое партнерство и силовое посредничество}

На деловом языке услуги силового партнерства обозначались скромной фразой «решать вопросы». Что это означало? На более ранних этапах преступные группировки занимались в основном простой физической охраной и страхованием от явного мошенничества («смотрели, чтобы не наезжали и не кидали»). Сюда же входило сопровождение торговых перевозок, в основном импорта, от границы до пункта назначения. «Был у нас вначале предприниматель, который ездил в Швецию за товаром. Мы встречали его у границы и сопровождали до Ленинграда. Но это были маленькие заработки и чаще конкретными товарами» [7].

По мере развития экономического рынка и стремительного роста числа сделок функции силового партнерства становились более сложными и разнообразными. Стандартной функцией силовых партнеров стало сопровождение сделок. Она заключалась в сборе информации о потенциальных партнерах или контрагентах, обмене гарантиями, контроле за выполнением обязательств. В случае возникновения осложнений силовые партнеры, представлявшие стороны в сделке, вырабатывали схемы их преодоления или возмещения ущерба и контролировали исполнение. Из интервью с бригадиром одной из петербургских ОПГ:

Bonpoc: А чем в основном занимались?

Oтвет: Чем конкретно занимались? Например, если у нас оптовый склад, то мы проверяли покупателей, собирали на них информацию, ездили смотрели их офис, находили возможности сделать так, чтобы они не кинули. В общем, работали, как обычная служба безопасности. Или встречались с партнерами других коммерсантов, которые просили об отсрочке. Мы их спрашивали: «Ручаетесь?» Они ручались. Или, наоборот, если наш коммерсант не мог расплатиться, мы вырабатывали схему погашения, рассчитывали, когда он сможет отдать и давали обязательства.

Bonpoc: А не проще ли кинуть - меньше усилий, легкий заработок?

Ответ: А зачем? Потом конфликт, или надо прятаться. Кидают, когда речь идет об очень больших деньгах [10].

По мнению и участников, и экспертов, большая часть контрактов на сумму более 10 тыс. долларов заключалась лишь при участии и под гарантии силовых партнеров, причем в качестве последних могли выступать самые разные лица или организации - от уголовных авторитетов до начальников служб безопасности или даже действующих сотрудников внутренних дел. Наиболее важным моментом в этой связи было взаимное признание силовых партнеров, основанное на предыдущем опыте, проверяемой информации и репутации. Если же у одной из сторон не оказывалось силового партнера, то либо снижалась вероятность заключения сделки, либо значительно возрастал риск - в зависимости от того, выступала ли эта сторона в качестве кредитора или получателя.

${ }^{35}$ Hendley, K. Legal Developments in Post-Soviet Russia, Post-Soviet Affairs, 1997. Vol. 13, No.3. P. 242. 
«Не так давно одна московская фирма наметила удачную сделку по следующей схеме: в Польше закупается партия шоколада (что с учетом всех накладных расходов обошлось бы в 25 тыс. долл. США) и перепродается в России оптовому покупателю за 50 тыс. долл. США. С поставщиком и покупателем были достигнуты договоренности, и дело оставалось за малым - получить в банке кредит. Но возникло неожиданное препятствие. Руководство банка поставило непременное условие, чтобы “крыша" заемщика встретилась со службой безопасности банка. Поскольку “крыши» у этой фирмы не было, ее руководителю пришлось обратиться к товарищу детства, который во взрослой жизни стал криминальным авторитетом: "Поприсутствуй на переговорах, как будто бы ты моя «крыша». В результате кредит был выдан"

«Решение вопросов» силовыми партнерами включало также отношения с государственной бюрократией по поводу получения лицензий, льгот, разрешений и т.п. для фирм клиентов. Наиболее ценным «активом» была далеко не всегда доступная способность «решать вопросы» с налоговой инспекцией - как для создания более благоприятных условий «своим» предприятиям, так и для оказания давления на конкурентов.

В целом на протяжении 1990-х гг. наблюдался сдвиг от угроз или прямого насилия в отношении должников или конкурентов в сторону использования в тех же целях государственных регулирующих органов (налоговой полиции, пожарной охраны, санитарно-эпидемиологического контроля). «Раньше, если кто-то там отказывался платить или создавал проблемы, просто сжигали магазин или, там, чью-нибудь машину. Теперь поняли, что проще и дешевле послать пожарную охрану, чтобы закрыть эту фирму или магазин, там, на неделю. Эффект один тот же» [9].

В какой форме происходит оплата силового партнерства? Эволюция силового партнерства описывается его участниками с помощью трех основных понятий: «получать» - «контролировать» - «быть в доле». «Получать» означает обложить какуюлибо торговую точку или фирму данью, охранять ее от других претендентов и, если ей нанесен ущерб, добиться компенсации. Размер дани лишь отдаленно соотносится с экономическими показателями или возможностями предприятия-клиента и устанавливается исключительно исходя из субъективных потребностей и оценок бандитов. Силовой партнер «контролирует» тот или иной бизнес, если он через «своего» аудитора или бухгалтера имеет доступ к информации о финансовой деятельности компании, финансовых потоках, всех ее операциях и контактах, обеспечивая надзор и подстраховку. Именно на этой стадии происходит перерастание охранного рэкета в отношения силового партнерства. Инвестиция денежных средств в развитие данной фирмы и вхождение представителей силового партнера в правление уже означают переход к долевому участию. Кроме отчислений в денежной форме (если есть возможности постоянного обналичивания средств), которые поддерживаются на уровне 20-30\% от прибыли, оплата силового партнерства может производиться во множестве других натуральных, наличных или безналичных форм (таких, как консультационные услуги, арендная плата, страховка, благотворительность и т.п.).

Многие силовые структуры и криминальные авторитеты занимались «долговой темой», когда к ним обращались с соответствующими запросами. Тогда они выступали в качестве единовременных посредников. Петр Скобликов в своем исследовании нелегального истребования долгов выделяет три основных метода улаживания долговой

${ }^{36}$ Скобликов П. Взыскание долгов. М.: Юрист, 1999. С. 73. 
проблемы. Первый метод предполагает встречу силовых партнеров кредитора и должника, и, если кредитор предоставляет убедительные доказательства задолженности, противоположная сторона может признать долг, гарантировать его возврат и оказать давление на «своего» задолжавшего бизнесмена для урегулирования проблемы. На практике это часто включает большой объем оперативной и информационной работы по нахождению должника, оценке его активов и установлению его силовых партнеров, если таковые имеются. В случае, если силовых партнеров нет, на должника или членов его семьи оказывается прямое давление, вплоть до насильственного отчуждения имущества. В таких случаях должник часто вынужден сначала подыскать силового партнера, а уже потом заниматься урегулированием самой проблемы. По разным оценкам, плата за возвращение долга таким способом колеблется в пределах $30-50 \%$ от его суммы.

Другой способ - откровенно криминальный. Он предполагает либо использование жестких угроз для того, чтобы заставить кредитора списать долг, либо физическое устранение кредитора в случае, если сумма долга значительно превышает затраты на организацию заказного убийства. Вероятность выбора именно этого решения - если отбросить моральные факторы - зависит от наличия у кредитора эффективного силового партнера. Согласно опросу предпринимателей, на жизнь которых были совершены покушения, в 40\% от них требовалось списать крупный долг ${ }^{37}$.

К третьему способу прибегают в ситуации, когда силовым партнерам не удается самим урегулировать проблему, и при этом они не рискуют прибегать к активным силовым действиям. В этом случае с согласия обеих сторон может быть привлечен вор в законе для решения проблемы по воровским понятиям, т. е. в соответствии с неформальным кодексом уголовного мира. Решение вора в таких случаях считается обязательным для обеих сторон, а его вознаграждение - те же «полдоли», то есть $50 \%$ от оспариваемой суммы. ${ }^{38}$

Функции силовых партнеров основаны на двух типах действия: реактивном и превентивном. Реактивное действие возникает в ситуации нанесения какого-либо ущерба членам силовой структуры или подконтрольным хозяйственным субъектам. В общем виде это действие направлено на то, чтобы добиться материальной компенсации ущерба посредством переговоров/угроз или нанести ответный ущерб другой стороне (как, например в случае «кидков» или других недобросовестных действий). На языке силовых предпринимателей это иногда называется «ответной комбинацией».

Превентивные действия направлены на контроль за будущим поведением других реальных или потенциальных участников деловых отношений, как за счет информационного обеспечения, так и за счет репутации и соответствующего эффекта сдерживания. Если реактивное действие часто включает угрозы и насилие, то превентивное предполагает демонстрацию силы без ее активного применения, а также использование информационных возможностей. В начале 1990-х гг. реактивные действия часто перерастали в конфликты, сопровождавшиеся значительными жертвами и экономическими издержками. Поначалу силовые партнеры (как, впрочем, и работавшие с ними бизнесмены) были больше заинтересованы в крупных единовременных доходах, получаемых любыми способами, включая невыполнение контрактных обязательств или невозврат кредитов. Однако это приводило к многочисленным силовым разрешениям споров. Постепенное осознание

\footnotetext{
${ }^{37}$ Мазеин В. Тактика выживания бизнесмена, коммерсанта // Мир безопасности, 1998, № 5. C. 23-27.

${ }^{38}$ Скобликов П. Взыскание долгов. М.: Юрист, 1999. С. 76-81.
} 
долговременных экономических интересов и соответственно стремление избежать дорогостоящих конфликтов, эффект репутации, а также формирование системы неформальных правил взаимодействия силовых партнеров друг с другом и $\mathrm{c}$ экономическими субъектами вызывали переориентацию силовых партнеров на превентивный контроль рисков, снижение уровня насилия и создание благоприятных условий для работы клиентов. Это вовсе не означает, что в один прекрасный день участники неформальных силовых структур вдруг стали более рациональными и решили ограничить уровень насилия. На самом деле рациональность, переориентация на долгосрочные интересы и последовавшие за этим изменения в способах действия силовых партнеров были, скорее, результатом конкуренции и вынужденной адаптации, нежели каким-либо осознанным проектом.

Еще одной формой силового посредничества стали так называемые «схемы обналичивания», т. е. выстраивание бартерных цепочек и контроль за ними с целью заработать на разнице между безналичной и наличной стоимостью товаров или услуг. Прибыль в таких «схемах» извлекалась за счет помещения в цепочку и продажи за наличные деньги товаров повышенного спроса (бензин, алкоголь, сахар или другие продукты $)^{39}$. Предприятиям, страдавшим от дефицита наличности и работавшим только благодаря бартеру, услуги специалистов по бартерным «схемам» позволяли выживать и продолжать работу в условиях рыночных ограничений, а силовым структурам (в основном, преступным группировкам) - извлекать доход, осуществляя контроль над участниками запутанных цепочек и обеспечивая обмен товарами в каждом из звеньев. Силовое посредничество, в отличие от силового партнерства, не предполагает постоянных отношений с какими-либо хозяйственными субъектами, а сводится к поиску посреднических возможностей. Тем не менее, оно сходно с другими способами силового предпринимательства в том, что так же основывается на способности управлять поведением других людей и тем самым контролировать выполнение соглашений.

С конца 1980-х гг. различные частные силовые структуры путем стихийного изобретательства, имитаций, проб и ошибок открывали и нарабатывали ряд действий, позволявших им на постоянной основе извлекать выгоду в условиях перехода к частной собственности и рыночному типу хозяйствования. Мы обозначили совокупность этих способов как силовое предпринимательство и условно выделили три вида: охрана, силовое партнерство и силовое посредничество. Охранные отношения (и охранный рэкет как пограничный случай) являются первой и наиболее простой формой силового предпринимательства, заключающейся в использовании силы для сдерживания потенциальных угроз, исходящих от других силовых структур. Силовое партнерство предполагает постоянные отношения владельцев средств насилия с хозяйствующими субъектами по контролю за рисками и выполнением этими субъектами контрактных обязательств, а также другие услуги, связанные с обеспечением благоприятной хозяйственной среды на предприятиях клиентов («деловое сопровождение»). Силовое посредничество - это оказание различных одноразовых или нерегулярных посреднических услуг при нахождении соответствующих возможностей или поступлении запросов (таких, как возврат долгов или разрешение хозяйственных споров, обналичивание средств и организация бартерного обмена).

При разнообразии практик и сфер приложения соответствующих навыков (сдерживание, обеспечение гарантий, сбор информации, оказание давления, нанесение ущерба, многочисленные формы переговоров и т.п.) каждый из трех основных видов силового предпринимательства содержит, по сути, один и тот же ключевой элемент - способность

\footnotetext{
${ }^{39}$ Пример бартерной «схемы» см. там же. С. 84-85.
} 
определять или ограничивать действия других участников экономической деятельности как посредством прямого принуждения, так и за счет влияния на их ожидания. Эта способность и представляет собой полезную функцию или «услугу», которая позволяет хозяйствующим субъектам продолжать или расширять свою деятельность («оставаться в бизнесе») и которая соответственно оплачивается ими на постоянной основе. Ее приобретение является вынужденным шагом, хотя в условиях разнообразия силовых структур конкретный ее поставщик может быть предметом выбора, а цена - предметом переговоров.

Структурным результатом деятельности силовых предпринимателей, отличным от непосредственных ими осознаваемых целей (получение дохода, выживание, расширение сферы деятельности), стало стихийное складывание системы ограничений, т.е. структурированной среды, упорядочивавшей действия участников (как хозяйственных субъектов, так и силовых структур) на непредсказуемых («диких») формирующихся рынках переходной экономики. Имея неформальный статус, эта совокупность правил и способов принуждения к их исполнению была далека от идеальных правовых систем по своей четкости и экономической эффективности. Тем не менее, она была более понятной, легко адаптируемой, а главное - более жестко контролируемой, чем находившаяся в зачаточном состоянии государственная система. 


\title{
ПОСТФОРДИСТСКИЕ КОНЦЕПЦИИ КАК ИССЛЕДОВАТЕЛЬСКАЯ ПРОГРАММА
}

\author{
Шевчук Андрей Вячеславович \\ к.э.Н., ГУ-ВШЭ \\ E-mail: shevchuk@pt.comcor.ru
}

\begin{abstract}
Введение
Экономическая социология в России переживает период становления, определения своего предмета и дисциплинарных границ. Однако стоит отметить, что сегодня она более тяготеет к анализу на микроуровне, в то время как внимание, уделяемое российскими экономсоциологами макроанализу хозяйственных систем, по нашему мнению, явно недостаточно. В этом отношении определенный интерес представляют так называемые «постфордистские концепции», являющиеся объектом анализа данной статьи.
\end{abstract}

Период с середины 1970-х гг. характеризуется целым рядом новых явлений и процессов, позволяющих говорить об эпохальной социально-экономической трансформации, переходе к новому витку общественного развития. Отечественным исследователям хорошо знакомы основные концептуальные трактовки происходящих изменений, лежащие в русле постиндустриальных теорий. Менее известны в России так называемые «постфордистские дебаты», трактующие современный этап как переход от «фордизма» к «постфордизму» ${ }^{1}$. Между тем за рубежом (прежде всего в западноевропейских странах) этой проблематике уделяется значительное внимание ${ }^{2}$, фактически постфордистские дебаты представляют собой сложившееся исследовательское направление: постфордистской тематике посвящаются научные конференции, монографии, в университетах читаются учебные курсы, защищаются диссертации, целый ряд журналов выступает ареной теоретических дискуссий ${ }^{3}$, сами термины «фордизм» и «постфордизм» вошли в словари, энциклопедии и справочные пособия по социальным наукам ${ }^{4}$.

Следует сразу отметить, что в отечественной науке сложился определенный стереотип восприятия термина «фордизм», который лежит в русле управленческих теорий, тогда

${ }^{1}$ Попытки дать целостное представление о них сделаны в работах автора. См.: Шевчук А.В. Постфордистские теории // Российский экономический журнал, 1999. № 4; Постфордистские концепции (критический анализ). Казань, 2000.

2 О важном месте постфордистских концепций в зарубежной науке говорит, например, тот факт, что в авторитетном исследовании К. Кумара они рассматриваются как одно из трех основных направлений в исследованиях современного общества наряду с теориями информационного общества и постмодернизма [См.: Kumar, K. From PostIndustrial to Post-Modern Society: New Theories of the Contemporary World. Oxford: Blackwell, 1995].

${ }^{3}$ В качестве журналов, наиболее часто обращающихся к постфордистской проблематике, можно назвать: Economy and Society, New Left Review, Capital and Class, New Political Economy и др.

${ }^{4}$ На русском языке доступно следующее издание: Большой толковый социологический словарь (Collins). М.: Вече, АСТ, 1999. С. 397-399. 
как в рассматриваемых концепциях он включает в себя более широкий круг явлений, охватывая различные области экономики, политики и культуры, связывая микро- и макроуровни анализа.

Основоположником такого подхода можно считать итальянского марксиста Антонио Грамши, который еще в 30-е гг. прошлого века в работе «Американизм и фордизм» заложил основы понимания фордизма как целостного социально-экономического и культурного явления 5 . В конце 1970-х гг. французский экономист Мишель Альетта впервые применил этот термин для характеристики послевоенного этапа социальноэкономического развития США 6 . Затем концепция фордизма была распространена и на другие промышленно развитые страны, а некоторые исследователи заговорили о «Глобальном фордизме» 7 . Современные дискуссии относительно траекторий социальноэкономического развития ведутся в терминах постфордизма ${ }^{8}$.

В данной статье мы надеемся частично восполнить существующий пробел и познакомить российского читателя с постфордистскими дебатами, очертив их предметное поле и представив основные (свое рода «классические») методологические подходы.

\section{Методологические подходы}

В рамках постфордистских дебатов обычно различают три основных направления: теорию регуляции, концепцию гибкой специализации, неошумпетерианские концепции 9 Вместе с тем наблюдаются попытки создания оригинальных теорий, которые лишь с существенными оговорками можно отнести к одному из перечисленных направлений. В этом отношении особо следует отметить обсуждение в постфордистских дебатах ряда постмодернистских концепций ${ }^{10}$.

Рождение постфордистских концепций в середине 1970-х гг. было вызвано неспособностью основного течения экономической мысли (мэнстрима) объяснить происходящие в развитых экономиках системные изменения. Так, приверженцы теории регуляции с самого начала подчеркивали отличие своей теории от ортодоксальных экономических доктрин. Их неудовлетворенность базируется на двух основных упущениях доминирующей экономической теории, сформулированных М. Альеттой. Во-

${ }^{5}$ Cм.: Gramshi, A. Americanism \& Fordism, in his: Selections from Prison Notebooks. L.: Laurence \& Wishart, 1971.

${ }^{6}$ Cм.: Aglietta, M. A Theory of Capitalist Regulation: The US Experience. L.: New Left Books, 1979.

${ }^{7}$ См.: Lipietz, A. Mirages and Miracles: the Crisis of Global Fordism. L.: Verso, 1987.

${ }^{8}$ См.: Amin, A. (ed.). Post-Fordism. Oxford: Basil Blackwell, 1994. и др.

${ }^{9}$ Cм.: Amin, A. Post-Fordism: Models, Fantasis \& Phantoms; and Elam, M. Puzzling out the Post-Fordist Debate: Technology, Markets and Institutions in: Amin, A. (ed.). PostFordism.

${ }^{10}$ Cм.: Harvey D. The Condition of Postmodernity: An Enquiry into the Origins of Cultural Change. Oxford: Blackwell, 1989; Lash S., and J. Urry. The End of Organized Capitalism. Cambridge: Polity Press, 1987; Economies of Signs and Space. L.: Sage, 1994; Hall, S. Brave New World, Marxism Today (October 1988); Gartman, D. Postmodernism or the Cultural Logic of Post-Fordism, Sociological Quarterly (1998). Vol. 39. Issue 1. и др. 
первых, ортодоксальные экономические теории в большинстве своем статичны (т.к. исходят из неизменности структурных условий) и неспособны плодотворно анализировать экономический процесс во времени. Во-вторых, они не в состоянии выразить социальное содержание экономических отношений и, вследствие этого, интерпретировать социальные силы и конфликты в экономическом процессе ${ }^{11}$.

\section{Теория регуляичии}

Теория регуляции ${ }^{12}$ является, пожалуй, наиболее влиятельной среди постфордистских концепций. Она знаменует возвращение к традициям политической экономии и черпает вдохновение преимущественно в марксистской традиции ${ }^{13}$, обогащенной идеями кейнсианства и экономической истории (в духе французской школы «Анналов»). Отправной точкой для регуляционистов является «феномен влияния всего комплекса общественных отношений на экономические закономерности» ${ }^{14}$.

Теорию регуляции прежде всего интересует, как «капитализму» удается развиваться, на каждом новом витке успешно преодолевая возникающие противоречия (при этом вопрос о его «неминуемом крахе» или «исторических границах», как правило, не ставится).

Базовыми категориями анализа в теории регуляции являются «режим накопления» [accumulation regime] и «способ социальной регуляции» [mode of social regulation]. Режим накопления (PH) - это макроэкономический режим, поддерживающий сбалансированные отношения между производством и потреблением. Имеется в виду взаимосвязь между трансформацией производства (производительность труда, степень механизации, сравнительная важность различных отраслей и т.п.) и трансформацией условий конечного социального потребления (структура спроса) ${ }^{15}$.

Однако стабилизация системы накопления не обеспечивается исключительно экономическими компонентами. Воспроизводство становится возможным благодаря развитию привычек, социальных норм, определенной политической практики, законодательства и т. д. Эти институциональные механизмы или «структурные формы» представляют собой кодификацию социальных отношений и составляют «способ социальной регуляции», который служит одновременно и для воспроизводства

${ }^{11}$ Aglietta, M. A Theory of Capitalist Regulation. P. 9., 19.

12 Разнообразие существующих подходов позволяет говорить о «школах регуляции» или «теориях регуляции». Некоторые исследователи выделяют в рамках теории до семи различных направлений (См.: Jessop, B. Regulation Theories in Retrospect \& Prospect, Economy and Society (May 1990). Vol. 19, No. 2.

13 Отличительной чертой теории регуляции является то, что практически все ее сторонники относятся к «левому» политическому спектру. Так, например, во Франции развитие теории в частности связано с Французской компартией, в Великобритании - с Конференцией экономистов-социалистов (The Conference of Socialist Economists). Отсюда и специфическая марксистская терминология («капитализм», «накопление», «воспроизводство» и т.п.).

${ }^{14}$ Буайе P. Теория регуляции. Критический анализ. М.: Наука для общества, РГГУ, 1997. C. 53.

15 Lipietz, A. Towards a New Economic Order: Post-Fordism, Ecology and Democracy. Cambridge: Polity Press, 1993. P. 2. 
социальных отношений, и для стабилизации процессов накопления ${ }^{16}$. Режим накопления и способ социальной регуляции формируют «способ развития» - модель устойчивого роста, характерную для определенного исторического периода ${ }^{17}$.

Подобные теоретические построения внешне напоминают классическую марксистскую конструкцию. Однако регуляционисты считают, что «неправильно устанавливать жесткую связь между производственными отношениями и определенным этапом развития производительных сил» ${ }^{18}$. Более того, они утверждают, что в рамках «капитализма» не существует единственного режима накопления или одного «правильного» способа социальной регуляции. Такой подход отличает теорию регуляции и от многих направлений «нового» институционализма. Если в рамках последнего предпринимаются попытки отыскать несколько общих способов экономической координации, действующих в совершенно различных географических и исторических условиях, то, согласно теории регуляции, режимы функционирования экономики различаются во времени и пространстве ${ }^{19}$. Таким образом, основное внимание здесь уделяется конкретным формам, принимаемым базовыми общественными отношениями в каждой исторической фазе данного общества.

Регуляционисты также считают весьма относительной зависимость жизнеспособности институтов от их экономической эффективности. «Происхождение институциональных форм связано с драматическими эпизодами истории, структурными кризисами, открытыми столкновениями между классами или социальными группами. И только позже каждой институциональной форме приходится доказывать свою совместимость с задачами экономического воспроизводства в течение более или менее длительного периода» ${ }^{20}$.

Таким образом, эволюция режима накопления и способа социальной регуляции представляет собой «открытие шансов» [chance discovery] ${ }^{21}$. Подобный теоретический

16 Развивая этот подход, исследователи в последнее время предлагают использовать применительно к сфере регуляции два термина, отражающие два ее уровня экономическую систему и общество в целом. Первый из них - «способ социальной регуляции экономики» [social mode of economic regulation], которым пользуется Б. Джессоп, удобен в силу того, что отражает как характер, так и объект регуляции. Второй - «способ социетализации» [mode of societalization] или «социетальная парадигма» [societal paradigm], касается процессов социальной регуляции, выходящих за рамки экономической системы. Речь идет о моделях массовой интеграции и социальной сплоченности на основе общности идеологий, ценностей, стилей жизни и т.п. Использование этой категории характерно для Й. Хирша, Б. Джессопа, А.Липетца. [См. их статьи в книге Post-Fordism, а также: Jessop, B. Regulation Theories in Retrospect and Prospect, Economy and Society (May 1990). Vol. 19, No. 2].

17 Следует отметить отсутствие последовательности в употреблении термина «режим накопления». Иногда он используется в смысле «способа развития». В этом случае к макроэкономическому режиму применяют термин «система накопления» [См.: Tickell, A., and J.A. Peck Accumulation, Regulation and the Geographies of Post-Fordism: Missing Links in Regulationist Research, Progress in Human Geography (1992). Vol. 16, No. 2].

${ }^{18}$ Буайе $P$. Теория регуляции. С. 78.

${ }^{19}$ Там же. С. 12.

${ }^{20}$ Там же. С. 10.

${ }^{21}$ Lipietz, A. Mirages and Miracles. P. 15. 
подход имеет ярко выраженную историческую направленность. Теория регуляции утверждает, что невозможно точно предсказать периоды роста и кризиса и их временные рамки вследствие зависимости от специфических исторических условий ${ }^{22}$.

\section{Неошумпетерианские конщепции}

Неошумпетерианское направление в постфордистских дебатах связано прежде всего с исследованиями инноваций Кристофера Фримана и Карлоты Перес ${ }^{23}$ и развивает идеи Н. Кондратьева о длинных волнах в развитии капитализма и Й. Шумпетера о ведущей роли предпринимателей-новаторов в экономическом процессе.

Ключевой категорией неошумпетерианцев является «технико-экономическая парадигма» - сфера производства и экономических отношений со всеми присущими ее проявлениями (технологиями, организационными и управленческими методами, распределением доходов, структурой общественного продукта и т.п.). По мнению К. Фримена, «длительный подъем является результатом не технических инноваций в одной или нескольких отраслях... а скорее диффузии новой технико-экономической парадигмы из нескольких ведущих секторов во всю остальную экономику и особенно в отрасли, производящие капитальные товары и соответствующие услуги» ${ }^{24}$. Технологическая революция ведет «не только к появлению нового ряда продуктов и услуг в соответствующих отраслях, но и отражается на всех других областях экономики посредством изменения стоимостной структуры затрат» ${ }^{25}$. Инновации толкуются широко и включают также (кроме новых продуктов и производственных процессов) новые формы организации труда и управления, новые навыки и умения, изменяющие качество рабочей силы, новые растущие сектора, новые транспортные и коммуникационные технологии, новое пространственное расположение производства и т.п.

Технико-экономическая парадигма вызревает в определенном социоинституциональном окружении, и переход от одной парадигмы к другой возможен лишь после адаптации множества социальных институтов к требованиям новых технологий. Процесс распространения новой группы технологий включает не только технологические, но и институциональные, социальные и даже поведенческие нововведения, сопровождающиеся сдвигами в общественном сознании. Таким образом, подрывается тезис о достаточности технологических изменений для порождения длинной волны, хотя признается их необходимость.

Возникающие время от времени системные кризисы трактуются как результат того, что обе подсистемы (технико-экономическая и социоинституциональная) развиваются с разной скоростью. Технико-экономическая подсистема имеет своим главным двигателем прибыль, стремление к увеличению которой приводит сначала к довольно быстрым сдвигам на микроуровне (отдельные предприятия), постепенно распространяющимся на

${ }^{22}$ В этом состоит коренное отличие от теории длинных волн, где «длина» волны четко определена.

${ }^{23}$ См.: Freeman, C., and C. Perez. Structural Crisis of Adjustment, Business Cycles and Investment Behavior, in: Dosi, G. (ed.). Technical Change and Economic Theory. L.: Frances Pinter, 1988.

24 Цит. по: Меньшиков С.М., Клименко Л.А. Длинные волны в экономике. М.: Международные отношения, 1989. С. 209.

${ }^{25}$ Там же. С. 211. 
всю экономику. Что касается социоинституциональной подсистемы, то она обладает большей инерцией, кроме того, институциональные изменения могут сдерживаться политической властью. Таким образом, технико-экономическая парадигма приближается к своим пределам раньше институциональной, и именно в ее недрах начинает вызревать новая система. К. Перес формулирует это следующим образом: «Истощение старой парадигмы сопровождается инерцией соответствующих социальных и институциональных механизмов», образуются «непреодолимые барьеры потенциальному росту новой технико-экономической парадигмы» ${ }^{26}$, что и ведет к структурному кризису.

Главное отличие неошумпетерианского подхода состоит в том, что технологическим изменениям отводится ведущая роль, в то время как социоинституциональные механизмы, хотя и в значительной степени учитываются, выглядят подчиненными технико-экономическим.

Концепции К. Фримена и К. Перес в отечественной научной литературе обычно относят к теориям длинных волн ${ }^{27}$. Однако часть западных авторов напрямую включает их в «постфордистские дебаты» ${ }^{28}$. Мы полагаем, для этого есть все основания. К. Фримен и К. Перес попытались наполнить кондратьевские длинные волны конкретным историческим содержанием, анализом как технико-экономических изменений, так и широкого спектра социоинституциональных изменений, отвергая механистические представления о связях между технологическими нововведениями и экономическим ростом. По нашему мнению, К. Фримен и К. Перес вышли за рамки традиционных подходов в теории длинных волн, существенно расширив проблематику исследования.

\section{Концеепция гибкой спецฺиализацฺии}

Абстрактная теория гибкой специализации отличается определенной концептуальной простотой, поскольку сфокусирована в основном на арене производства. Толчком для ее развития послужила работа М. Пиоре и Ч. Сэйбла «Второй индустриальный перелом» ${ }^{29}$.

В экономике сосуществуют две индустриальные парадигмы, каждая из которых не содержит априори технологического превосходства над другой. С одной стороны, это массовое производство стандартизированных товаров с использованием специального (рассчитанного на одну задачу, привязанного к одному продукту) оборудования и полуквалифицированной рабочей силы. С другой стороны - гибкая специализация (ремесленное производство): производство разнообразных товаров небольшими партиями с использованием многоцелевого оборудования и квалифицированного труда.

Для М. Пиоре и Ч. Сэйбла массовое производство и гибкая специализация являются не только парадигмами производства, но и исторически реализуются в типах экономики,

${ }^{26}$ Там же. С. 236.

${ }^{27}$ См.: Меньшиков С.М., Клименко Л.А. Длинные волны в экономике; Длинные волны в экономике. Научно-технический прогресс и социально-экономическое развитие / Под ред. С.Ю. Глазьева, Г.И. Микерина, П.И. Тесля и др. Новосибирск: Наука, 1991; Полетаев A.В., Савельев И.М. Циклы Кондратьева и развитие капитализма. М.: Наука, 1993.

${ }^{28}$ CM.: Amin, A. Post-Fordism: Models, Fantasis \& Phantoms; Elam, M. Puzzling out the PostFordist Debate: Technology, Markets and Institutions, in: Amin, A. (ed.). Post-Fordism.

${ }^{29}$ См.: Piore, M., and C.F. Sabel. The Second Industrial Divide. N.Y.: Basic Books, 1984. 
где один тип производства доминирует на определенной географической территории: в регионе, национальном государстве или мировом масштабе.

Каждому из вышеописанных типов экономики присущи свои специфические экономические проблемы. Массовое производство развивается за счет инвестиций в новые поколения специализированного оборудования, что позволяет наращивать «экономику масштабов», снижая издержки и цену продукции. Но если рынок не способен поглотить всю произведенную продукцию, производитель начинает испытывать на себе бремя высоких постоянных издержек и негибкой производственной системы. Таким образом, высокая специализация дает отдачу только в случае рыночной стабильности. Для ее достижения необходимы определенные регулятивные институты, поддерживающие баланс между производством и потреблением. Крушение подобных институциональных механизмов приводит к «кризису регуляции». Выход из кризиса возможен с помощью реконструирования механизмов регуляции или инноваций. Если основной проблемой экономики массового производства является стабилизация рынка, то основная проблема для гибкой специализации - поддержание технического динамизма, т.е. постоянный инновационный процесс. В последнем случае приспособление к рынку не является сложной задачей, поэтому значение механизмов регуляции снижается. Однако гибкая специализация связана с риском стагнации технологического развития.

В определенные моменты истории одна индустриальная парадигма может существенно ограничить другую и стать всеобщим стандартом. Эти поворотные точки названы «индустриальными переломами» [industrial divides]. Объясняя победу той или иной парадигмы, Пиоре и Сэйбл отвергают какой бы то ни было «железный закон» исторической необходимости во избежание технологического или рыночного детерминизма. По мнению авторов, все зависит от политического выбора различных экономических субъектов (фирм, профсоюзов, национальных правительств) и распределения финансовых ресурсов. «Технические возможности зависят от распределения власти и богатства: те, кто контролирует ресурсы и получает выгоду от вложений, делают выбор технологии в пользу наиболее выгодной для своих интересов» ${ }^{30}$. Пиоре и Сэйбл утверждают, что будущее зависит от «социальной борьбы, а не от естественных законов развития» ${ }^{31}$. Новая технологическая парадигма создает также новые «представления об эффективном производстве», которые активно пропагандируются. Таким образом, триумф индустриальной парадигмы зависит от материальной и идеологической поддержки.

\section{Траектории социально-экономического развития в свете постфордистских концепций}

Важным моментом, объединяющим различные концепции в рамках постфордистских дебатов, является общий подход к периодизации социально-экономического развития в $\mathrm{XX}$ в. с использованием категорий «фордизма» и «постфордизма». Основу этого подхода, как мы уже отмечали, составляет анализ технико-экономической и социоинституциональной подсистем в их взаимодействии. В теории регуляции это выражается в категориях «режим накопления» и «способ социальной регуляции». У неошумпетерианцев подобный подход представлен анализом «вызревания» «технико-

\footnotetext{
${ }^{30}$ Ibid. P. 38.

${ }^{31}$ Ibid. P. 15.
} 
экономической парадигмы» в определенном «социоинституциональном окружении», а в концепции гибкой специализации - выделением двух «производственных парадигм» (массового и гибкого производства), доминирование каждой из которых зависит от «политических решений» и «институционального выбора». Несмотря на то, что взаимодействие между вышеприведенными категориями варьируется (от выраженного технологического детерминизма у неошумпетерианцев, через взаимовлияние у регуляционистов, до доминирования специфических «исторических условий» и «политических решений» у теоретиков гибкой специализации), позиции исследователей сходятся в том, что долговременный и устойчивый экономический рост возможен только на основе гармоничного сочетания технико-экономической и социоинституциональной подсистем. Историческая и пространственная специфика этого сочетания характеризуют определенный этап общественного развития и его страновые (региональные) модификации. Таким образом, в концепциях ясно просматриваются исторический и социокультурный подходы.

Логика социально-экономического развития в XX веке с точки зрения постфордистских концепций в общих чертах может быть представлена следующим образом [см. табл. 1].

Таблица 1. Периодизация социально-экономического развития в XX в.

\begin{tabular}{|c|c|c|c|c|}
\hline & $\begin{array}{c}\text { До первой } \\
\text { мировой войны }\end{array}$ & $\begin{array}{c}\text { Между } \\
\text { мировыми } \\
\text { войнами }\end{array}$ & $\begin{array}{c}\text { После второй } \\
\text { мировой войны }\end{array}$ & $\begin{array}{c}\text { Последняя четверть } \\
\text { XX в. }\end{array}$ \\
\hline $\begin{array}{c}\text { Историческая } \\
\text { эпоха }\end{array}$ & & & Фордизм & $\begin{array}{c}\text { Постфордизм? } \\
\text { Неофордизм? } \\
\text { Затянувшийся } \\
\text { структурный кризис? }\end{array}$ \\
\hline $\begin{array}{c}\text { Технико- } \\
\text { экономическая } \\
\text { подсистема } \\
\text { (сфера } \\
\text { накопления) }\end{array}$ & $\begin{array}{c}\text { Преимущественно } \\
\text { экстенсивная }\end{array}$ & $\begin{array}{c}\text { Появление } \\
\text { фордистской } \\
\text { интенсивной }\end{array}$ & $\begin{array}{c}\text { Фордистская } \\
\text { интенсивная } \\
\text { (на основе массового } \\
\text { производства и } \\
\text { потребления) }\end{array}$ & $\begin{array}{c}\text { Кризис фордистской } \\
\text { Появление: } \\
\text { гибкой? } \\
\text { неофордистской? }\end{array}$ \\
\hline $\begin{array}{c}\text { Социо- } \\
\text { институ- } \\
\text { циональная } \\
\text { подсистема } \\
\text { (сфера } \\
\text { социальной } \\
\text { регуляции) }\end{array}$ & Конкурентная & $\begin{array}{c}\text { Кризис } \\
\text { конкурентной }\end{array}$ & $\begin{array}{c}\text { Монополистическая } \\
\text { (административная, } \\
\text { фордистско- } \\
\text { кейнсианская) }\end{array}$ & $\begin{array}{c}\text { Кризис } \\
\text { монополистической } \\
\text { Появление: } \\
\text { неоконкурентной } \\
\text { (неолиберальной)? } \\
\text { неокорпоративной? } \\
\text { неостейтистской? }\end{array}$ \\
\hline
\end{tabular}

Фордизм

В XIX в. разрозненные региональные экономики базировались в основном на ремесленном производстве, а экономический рост осуществлялся на экстенсивной основе, вовлекая в кругооборот дополнительные ресурсы (практикуя захват новых географических пространств, увеличение продолжительности рабочего дня и т.п.). Социальная регуляция 
носила конкурентный характер, государство придерживалось политики невмешательства в экономику.

Первый «индустриальный перелом» относится к началу нашего столетия, когда на базе организационных и технологических инноваций Ф. Тейлора и Г. Форда начала формироваться система массового производства. В ее основу положены следующие принципы: стандартизация продукции, механизация производства, научный менеджмент (тейлоризм), конвейер. Г. Форд понимал, что становление экономики массового производства непременно должно быть связано с соответствующими изменениями со стороны спроса. Поэтому символической датой рождения фордизма считается 1914 г., когда Г. Форд ввел знаменитый пятидолларовый восьмичасовой рабочий день, чтобы у рабочего появилось достаточно средств и свободного времени для потребления товаров массового производства. Он также осознал, что новая индустриальная система подразумевает новую модель воспроизводства рабочей силы, новую политику управления и контроля труда, новую психологию и стиль жизни рабочего, новую эстетику и мировосприятие. В социофилософских измышлениях и практической деятельности Г. Форда отразились основные направления формирования качественно новой социально-экономической системы, которая впоследствии и была названа исследователями в его честь ${ }^{32}$.

Не без труда преодолевая препятствия на своем пути, явив миру глубочайший кризис (Великую депрессию), эта система окончательно сформировалась только после Второй мировой войны. Основу нового институционального порядка составили всеобъемлющий социальный компромисс (который часто именуется «фордистским») и новая, активная роль государства. Суть компромисса заключалась в том, что наемные рабочие (в лице мощных профсоюзов) согласились принять фордистские методы труда и их негативные последствия (дегуманизация, высокая интенсивность, монотонность и т.п.) в обмен на более высокий уровень жизни, а работодатели - поделиться с рабочими частью прибыли от возросшей производительности ${ }^{33}$.

Примечательно, что «национальные правительства разной идеологической направленности - де Голль во Франции, лейбористская партия в Англии, христианские демократы в ФРГ - приложили все усилия для достижения компромисса и обеспечивали экономический рост и рост уровня жизни посредством реализации "государства благосостояния", кейнсианской модели управления спросом и контроля за отношениями найма» ${ }^{34}$.

${ }^{32}$ См.: Форд Г. Моя жизнь. Мои достижения. М.: Финансы и статистика, 1989.

${ }^{33}$ Следует обратить внимание на разницу между терминами «фордистский компромисс» и «социальное партнерство», которые используются, по сути, для описания одного и того же явления. Первый подчеркивает, прежде всего, конфликтность интересов работодателей и наемных работников: с одной стороны, интересов повышения производительности с помощью фордистских технологий и, с другой стороны, интересов личности, стремящейся к творческому труду. Слово «компромисс» отражает элемент «сделки», в которой каждая сторона не только приобрела определенные выгоды, но и пошла на существенные уступки. Напротив, широко употребляемый сегодня термин «социальное партнерство» скрывает эти противоречия и создает иллюзию изначальной гармонии интересов.

${ }^{34}$ Harvey, D. The Condition of Postmodernity. P. 135. 
Таким образом, сложился новый «монополистический», «административный» или «фордистско-кейнсианский» способ социальной регуляции, который в сочетании с «интенсивным» или «фордистским» режимом накопления позволил в течение нескольких десятилетий поддерживать беспрецедентные в истории темпы экономического роста, приблизиться к полной занятости и достичь высокого уровня благосостояния населения.

Вообще господство фордистских принципов выходило далеко за рамки экономической системы. В политике, например, они проявлялись в существовании массовых политических партий и движений, государстве благосостояния, где идея стандартизированного продукта получила демократическую интерпретацию как универсальная услуга для удовлетворения одинаковых базовых потребностей ${ }^{35}$. В сфере культуры эти принципы можно обнаружить в «американском» стиле жизни (гедонистической концепции счастья, выражающейся в потреблении все большего количества товаров), функциональной эстетике (соответствующей возможностям массового производства), монументальной архитектуре и Т.П.

Кризис фордизма, разразившийся в середине 1970-х гг., также в равной степени проявился и в снижающейся экономической эффективности, и в общекультурной неудовлетворенности «обществом одного измерения», квинтэссенцией которой стали массовые выступления трудящихся, молодежи и студентов во Франции в конце 1960-х гг. В объяснении этого кризиса теория регуляции акцентирует внимание на истощении тейлористской модели трудового процесса. Более высокий уровень образования, выросшее самосознание и желание получать удовлетворение от работы привели к сопротивлению наемных работников подобным методам организации труда, а высокая зарплата уже не могла компенсировать их негативные последствия. Регуляционисты подчеркивают также обострение противоречий между растущей глобализацией производства и рынков и национальным характером механизмов регуляции. Вся фордистская система базировалась на относительной замкнутости национальной экономики, в рамках которой поддерживалась сбалансированная связь между производством и потреблением. Глобализация производства и рост мировой торговли нарушили этот баланс. Адекватные механизмы регуляции, призванные контролировать связь между производством и потреблением в глобальном масштабе, отсутствовали: не было ни международных соглашений для сбалансированности роста в разных странах, ни международных коллективных переговоров, ни наднационального государства благосостояния ${ }^{36}$. Теоретики гибкой специализации также обращают внимание на насыщение массовых рынков и фрагментацию спроса, возникающие вследствие развивающейся дифференциации стилей жизни, а неошумпетерианцы - на диффузию технологических инноваций, способных стать мотором нового роста.

\section{Постфордизм}

Практически все постфордистские концепции приходят к некоторому консенсусу относительно уходящей эры фордизма и ее кризиса, однако взгляды на будущее существенно различаются.

Концепция гибкой специализации наиболее известна своими изысканиями в области характера труда и промышленных организаций в современных условиях. Период с

\footnotetext{
${ }^{35}$ Murrey R. Life after Henry Ford, Marxism Today (October 1988). P. 9.

${ }^{36}$ Cм.: Lipietz, A. Towards a New Economic Order. P. 14-19.
} 
начала 1970-х гг. рассматривается как второй индустриальный перелом, открывающий возможности для возрождения ремесленного производства в качестве доминирующей индустриальной парадигмы. По мнению теоретиков гибкой специализации, именно эта модель способна с минимальными издержками обеспечить производство высококачественных товаров для специальных и изменчивых рынков. Идеальному типу гибкого производства в целом присуще следующее ${ }^{37}$ :

- разделение задач в производственном цикле между специалистами, автономными группами или независимыми фирмами таким образом, чтобы каждая единица могла максимизировать «экономику масштабов» и экспертизу, полученную от специализации в одной области, и одновременно иметь возможность варьировать конечный продукт по количеству и форме без потери общей эффективности;

- отказ от тейлоризма (опора на навыки, многофункциональность, участие рабочих в борьбе за качество продукции и приток идей; реинтеграция умственной и физической работы);

- децентрализация механизма принятия решений (для уменьшения отчуждения рабочих, усиления их ответственности и повышения скорости реагирования на изменяющиеся рыночные сигналы);

- развитие многоцелевых технологий, гибко приспособляемых к различным задачам и объемам;

- культура сотрудничества, развитие переговорного процесса между фирмами и внутри фирм как ключевое условие, поддерживающее необходимую взаимозависимость и гибкость.

Таким образом, гибкая специализация обещает установить новые демократичные индустриальные отношения, основывающиеся на кооперации и доверии между рабочими и работодателями, рисуя в целом «розовую» модель будущего. Регуляционисты же более критичны, некоторые из них видят дальнейшее развитие в рамках «неофордизма», связанного с автоматизацией массового производства и дальнейшей дегуманизацией труда (когда работнику остается только следить за работой оборудования) ${ }^{38}$. И если гибкая специализация делает ставку на фрагментацию рынков и работу на определенные ниши, то неофордизм возлагает надежды на стандартизацию в мировых масштабах, поставку на все рынки унифицированной продукции.

По мнению неошумпетерианцев, в основу нового этапа развития («пятой волны Кондратьева») лягут информационные технологии, а основу новой хозяйственной системы составят отрасли, их интенсивно использующие (компьютеры, программное обеспечение, телекоммуникации, робототехника, электронные базы данных и информационные услуги). Однако сами по себе высокие темпы роста новейших отраслей хозяйства, связанных с производством вычислительной техники, телекоммуникаций, полупроводников, не являются основанием для выводов о начале нового этапа развития. Эти отрасли занимают относительно небольшое место в современной социальноэкономической структуре, что проявляется, в частности, в незначительном воздействии их бурного распространения на общие темпы экономического роста.

Постфордистские дебаты пролили свет на целый ряд производственных и организационных инноваций. Однако только в последнее время начались серьезные

\footnotetext{
${ }^{37}$ Amin, A. Post-Fordism: Models, Fantasies and Phantoms. P. 21.

${ }^{38}$ Cм.: Aglietta, M. A Theory of Capitalist Regulation.
} 
исследования возникающих политических структур и государственных форм, развернулась острая полемика по поводу новых механизмов регуляции.

Приверженцы концепции гибкой специализации следующим образом обосновывают новые политические приоритеты: необходимо отказаться от классической кейнсианской стратегии управления спросом (массовое производство не является более жизненно важным), направляемого государством промышленного планирования (центральные институты - негибкие), государственной политики, поддерживающей концентрацию собственности и экономику масштабов (гигантизм неэффективен и негибок). Ставка делается на локальные решения, политику, выработанную в регионах, где с успехом развивается гибкая специализация (например, в «третьей» Италии) ${ }^{39}$. Необходимо наличие политических, нормативных и организационных средств для создания отношений, поддерживающих кооперацию и координацию, культуру локальной идентификации и доверия, как для развития региональной сети малых фирм, так и для реорганизации мультинациональных корпораций в созвездие полуавтономных единиц, включенных в местную экономику. Концепция гибкой специализации предвещает возврат к самоподдерживающимся региональным экономикам, подобным тем, что существовали до середины XIX в. ${ }^{40}$

Трактовка неошумпетерианцами истории капитализма как цепочки технологических революций определяет и их представления о надлежащей экономической политике государства. Прежде всего, подчеркивается, что общество еще не готово в полной мере к восприятию новой технико-экономической парадигмы; существующие институты нацелены на защиту сложившейся технологической структуры и препятствуют широкому распространению новых технологических принципов, что продиктовано стремлением защитить ранее сделанные затраты. Требуются существенные изменения в институциональных приоритетах и политике. На уровне государственного регулирования это предполагает определение важнейших стратегических технологий и осторожную спланированную интервенцию с целью устранить барьеры, препятствующие их развитию, а также массированные вложения в развитие новой инфраструктуры и улучшение качества рабочей силы. Нужно поощрять новые сектора промышленности, технологическое перевооружение фирм, распространение новых стандартов и коммуникационных систем, поддерживать идущих на риск предпринимателей и инвестировать в образование и обучение в соответствующих областях.

Регуляционисты подчеркивают важность формирования новых механизмов регуляции. Однако мнения относительно их характера существенно различаются. Выделяются три принципиальных варианта: неолиберализм, неостейтизм, неокорпоративизм ${ }^{41}$.

Неолиберализм связан с ведущей ролью рынка и основывается на дерегуляции, приватизации, либерализации, поддержании гибкости рынка труда, реорентации

39 О так называемых «новых индустриальных районах» см.: Scott, A. New Industrial Spaces: Flexible production Organisation and Regional Development in North America and Western Europe. L.: Pion, 1988.; Scott, A. Flexible Production System \& Regional Development: The Rise of New Industrial Spaces in North America and Western Europe, The International Journal of Urban and Regional Research (1988). No. 12 и др.

${ }^{40}$ Sabel, C.F. Flexible Specialization and the Re-emergence of Regional Economies, in: Amin, A. (ed.) Post-Fordism. P. 103.

${ }^{41}$ Jessop, B. Post-Fordism and the State. P. 266. 
государственной деятельности на нужды частного сектора, использовании коммерческого критерия в госсекторе, отказе от механизмов социального партнерства в сторону рыночных сил, космополитизме и содействии глобализации. В этом случае инновации возникают спонтанно, под действием духа предпринимательства.

Неокорпоративизм подразумевает согласование и координацию деятельности экономических агентов, ориентированные на реализацию общих интересов. Фордистский корпоративизм был нацелен главным образом на достижение полной занятости. Неокорпоративизм смещается на микроуровень и, отражая растущую гетерогенность рынка труда и интересов различных сообществ, ориентирован на инновации и структурную конкурентоспособность. Неокорпоративизм распространяется не только на экономическую (отношения труда и капитала), но и на другие функциональные системы (наука, образование, медицина). Неокорпоративизм связан с интегрированием перспективных интересов, усилением ядра и исключением периферии. Роль государства заключается в поддержке решений, достигнутых в ходе корпоративных переговоров. В отличие от неолиберализма неокорпоративизм предстает как «регулируемая саморегуляция» ${ }^{42}$.

Сущность неостейтизма состоит в том, что экономическая реорганизация осуществляется исходя из государственных, а не частных или корпоративных интересов. Неостейтизм основан на активной роли государства и нацелен на усиление структурной конкурентоспособности. В более конкретном плане можно отметить важную роль технологической политики продвижения инноваций, политики отраслевой реструктуризации, политики государства на рынке труда, направленной на эффективную занятость и т. п.

На практике элементы этих стратегий могут комбинироваться. Так, в рамках Европейского Союза сосуществуют единый рынок (неолиберализм), политика координирования регионального развития новых технологий, образовательных и научноисследовательских центров, банковских институтов (неостейтизм), социальный характер экономики и предотвращение социального демпинга (неокорпоративизм).

Самые большие споры касаются, пожалуй, статуса неолиберализма. В то время как одни считают, что именно он станет основой нового способа социальной регуляции, другие акцентируют внимание на его многочисленных негативных эффектах (возрождение интенсивной конкуренции при упадке институциональной координации конечного выпуска продукции и рынков труда, усиливающаяся сегментация рынка труда и дифференциация доходов, снижение политической силы профсоюзов и т.п.).

Противники неолиберализма считают, что он представляет собой скорее «вакуум», «отсутствие эффективных механизмов регуляции» и неприемлем в условиях масштабной структурной трансформации. Переход к монетаристским стратегиям со стороны государства - скорее «тактическая реакция на кризис, а не его разрешение», политическая суть проблемы, «политика кризиса», когда экономический рост замедлился и социальный компромисс рухнул. Он не является базой для самовоспроизводящегося и устойчивого экономического роста ${ }^{43}$. Новый компромисс должен быть направлен на поддержание экономической, социальной и экологической стабильности.

${ }^{42}$ Ibid. P. 267.

${ }^{43}$ Peck, J., and A.Tickell Searching for New Institutional Fix, in: Amin, A. Post-Fordism. P. 296. 
Некоторые исследователи связывают надежды на будущее с развитием наднациональных механизмов регуляции, в том числе на базе сложившихся политикоторговых блоков (EC, NAFTA, ASEAN). Приверженцы этой точки зрения считают, что разрешение кризиса должно идти не снизу (через конкуренцию), а сверху (через национальное и мировое сотрудничество $)^{44}$. С другой стороны подчеркивается ограниченность возможностей наднациональных институтов и смещение акцента их деятельности с регулирования международной торговли, валютных отношений и иностранных инвестиций в сторону поддержания в глобальной конкурентной борьбе структурной конкурентоспособности самого территориального образования ${ }^{45}$.

Значительная часть исследователей полагает, что хотя в сфере производства и происходят весьма значимые эксперименты, говорить о появлении нового способа социальной регуляции, a, следовательно, и стабильной модели развития, преждевременно. Поэтому, в отличие от теоретиков гибкой специализации и неошумпетерианцев, четко определивших составляющие будущего режима, регуляционисты, в целом, более сдержанны в предсказаниях о том, какая эра придет после фордизма. Они видят настоящий период как серию экспериментов с различными стратегиями преодоления кризиса ${ }^{46}$. Постфордизм приобретает ясные очертания в конфронтации между противоборствующими тенденциями. Поэтому регуляционисты не спешат зафиксировать имя новой эры и колеблются в выборе между терминами: «nеоfordism» - чтобы показать тесную связь с фордизмом и преемственность ${ }^{47}$, «post-fordism» - как разрешение кризиса ${ }^{48}$ и «after-fordism» - для обозначения скорее кризисного периода после фордизма, чем новой фазы развития ${ }^{49}$. В целом, для обозначения современной эпохи в дебатах принят более устоявшийся (хотя и по-разному интерпретируемый) термин «постфордизм» (post-fordism) ${ }^{50}$. Когда же составляющие новой модели развития будут окончательно определены, она, по-видимому, получит другое, более содержательное имя.

Следует отметить, что рост популярности постфордистских концепций неизбежно был связан с упрощением и вульгаризацией трактовок фордизма и постфордизма. Главным образом, это касается инициированного теоретиками гибкой специализации прямого противопоставления фордизма и постфордизма как эпох массового производства и

${ }^{44}$ CM.: Lipietz, A. Towards a New Economic Order. P.27; Peck, J., and A. Tickell. Searching for New Institutional Fix. P. 311.

45 Jessop, B. Post-Fordism and the State. P. 270.

${ }^{46}$ CM.: Esser, J., and J. Hirsch. The Crisis of Fordism and the Dimensions of a Post-Fordist Regional and Urban Structure, in Amin, A. Post-Fordism; Peck, J., and A. Tickell. Searching for New Institutional Fix; и др.

${ }^{47}$ Cм.: Aglietta, M. A Theory of Capitalist Regulation.

${ }^{48}$ См.: Jessop B. Post-Fordism and the State.

${ }^{49}$ См.: Peck, J., and A. Tickell. Searching for New Institutional Fix.

${ }^{50}$ Существуют некоторые языковые трудности с переводом вышеупомянутых терминов, так как английские «post-fordism» и «after-fordism» могут быть переведены на русский язык одним термином «постфордизм». Таким образом, важное значение приобретает смысловое наполнение этого термина. В настоящей работе термин постфордизм используется скорее в духе термина «after-fordism» (как период кризиса и неопределенности дальнейшего развития). 
гибкой специализации, что зачастую приводит к карикатурному представлению исторического развития ${ }^{51}$. Конечно, нельзя согласиться с представлением будущего как прямой противоположности прошлого, игнорируя существующую преемственность. И все же следует отметить, что современные изменения многими описываются с помощью контрастных противопоставлений, принимающих форму бинарной истории (индустриальное - постиндустриальное, модернистское - постмодернистское, экономическое - постэкономическое общества, организованный - дезорганизованный капитализм и т. п.). По-видимому, это связано с тем, что противопоставление является мощным аналитическим средством регистрации различий, и это особенно важно для концептуализации происходящих изменений.

В этой связи некоторые исследователи считают термин «постфордизм» вполне удачным и предлагают оригинальную трактовку, утверждая, что он несет в себе существенные элементы и дискретности, и континуальности. Без первых он не был бы постфордизмом, без вторых - постфордизмом ${ }^{52}$. Таким образом, постфордизм является результатом развития тенденций, зародившихся в самом фордизме, при этом знаменуя существенный разрыв с ним и разрешая противоречия, приведшие его к кризису.

\section{Основные выводы}

Сложность и многоаспектность самой проблемы социально-экономического развития предопределила то, что постфордистские концепции, не складываясь в монолитную теоретическую систему, скорее являются отдельной областью дискуссий (известной как «постфордистские дебаты»), открытой исследовательской программой. Тем не менее, эти дискуссии ведутся в общей системе координат: они объединены общим предметом и методологическими основами исследования.

Постфордистские концепции являются альтернативным направлением экономической мысли, смыкающимся с широким спектром социальных наук и в том числе с экономической социологией. Главные отличия от основного течения экономической науки (мэйнстрима) заключаются в следующем:

- отказ от равновесного анализа, рассмотрение экономических явлений в процессе и с позиций их эволюции;

- отказ от модели «homo economicus» и экономического детерминизма, признание социокультурной обусловленности экономического действия;

- отказ от контрактной модели социально-экономических отношений, признание того, что они отражают в том числе отношения господства и подчинения между различными социальными силами;

51 Представление о современной эпохе как «конце массового производства» обстоятельно критикуется целым рядом авторов [см. например: Williams, K., Cutler, T., William, J., and C. Haslam. The End of Mass Production?, Economy and Society (1987). No. 16]. По нашему мнению, для утверждений о конце эпохи массового производства, конечно, нет достаточных оснований. Однако сам характер массового производства, формы трудового контроля, отношения между крупным и мелким бизнесом существенно изменяются, на что критики не обращают должного внимания.

52 Jessop, B. Post-Fordism and the State. P. 257. 
- отказ от методологического индивидуализма, рассмотрение социальноэкономических процессов с позиций холизма.

Предметом исследования постфордистских концепций является развитие «капитализма» в долговременной перспективе, при этом используются сходные трактовки его этапов с использованием категорий «фордизм» и «постфордизм».

Методологический подход к исследованию социально-экономического развития основывается на анализе технико-экономической и социоинституциональной подсистем в их взаимодействии. Причем особое внимание, уделяемое изучению институциональных изменений, а также ряд нижеприведенных теоретических положений относительно роли институтов в социально-экономической системе позволяют рассматривать постфордистские концепции как одно из направлений институционализма, более тяготеющее к его «старой» традиции, чем к неоинституционализму:

- институты ограничивают и направляют действия субъектов социально-экономической системы;

- институты как устойчивые формы взаимодействия между людьми поддерживают преемственность и стабильность в течение сравнительно длительных периодов, их сменой объясняются качественные изменения и прерывистость процесса развития;

- институты являются предметом и результатом борьбы различных социальных сил за изменение их конфигурации, воплощая в себе определенные социальные компромиссы на каждом этапе развития;

- в институтах реализуется национальная социокультурная специфика.

Отметим также, что постфордистские исследования ориентированы главным образом на анализ институциональных комплексов, связанных с фундаментальными социальными отношениями $^{53}$, а также институциональной структуры в целом, в отличие от программы неоинституционалистов, предпочитающих изучать отдельные институты на микроуровне.

Несколько слов необходимо сказать и о соотношении постфордистских и постиндустриальных теорий. Несмотря на то, что в центре внимания обоих направлений находятся практически одни и те же социально-экономические явления и процессы, их исследовательские ориентации все же в значительной степени отличаются. Постфордистские концепции работают на более низком уровне абстракции, нежели постиндустриальные теории, претендующие на периодизацию общественного развития в целом. Из этого вытекает в конечном счете более скромная оценка масштабов перемен: речь ведется лишь об окончании эпохи фордизма. Кроме того, для постфордистских концепций характерно стремление разработать теоретический инструментарий для исследований социально-экономического развития (движущих сил, механизмов социально-экономических трансформаций, временно́й и пространственной неравномерности развития, возникающих противоречий и т.п.), в то время как постиндустриальные теории носят в значительной степени описательный характер и сосредоточены главным образом на изучении и социально-философском осмыслении «постиндустриальных тенденций».

53 Так, Р. Буайе выделяет среди них деньги, отношения найма, формы конкуренции, государство, способ присоединения к международному режиму [См.: Буайе Р. Теория регуляции. С. 85-91]. 
Одно из основных уязвимых мест постфордистских концепций в их «классическом» виде - избыток функционализма и объективизма. Чрезмерный акцент на институтах как механизмах регуляции привел к потере активного начала в процессе общественного развития. Социально-экономическое пространство предстает чрезмерно зарегулированным, а институциональные изменения зачастую трактуются как выражение некой абстрактной «логики накопления». Осознание этих недостатков вызвало повышенный интерес к анализу государства как субъекта социальноэкономической политики ${ }^{54}$, что в свою очередь таит в себе потенциальную опасность скатывания к традиционной дихотомии: экономическая система - государство. Однако в целом в 1990-е гг. в рамках постфордистских концепций неудовлетворенность функционалистскими трактовками постоянно нарастала, что выразилось в новых попытках осмысления взаимодействия социально-экономической структуры и социального действия ${ }^{55}$.

Мы полагаем, что постфордистские концепции способны обогатить существующие в современной России теоретические подходы к проблемам социально-экономического развития. В заключение позволим себе высказать несколько самых общих соображений по этому поводу. Так, например, в рамках постфордистских концепций большое внимание уделяется национальным модификациям фордизма и постфордизма как этапов общественного развития ${ }^{56}$. Почему бы не взглянуть на советскую систему, используя наработки постфордистских концепций ${ }^{57}$ Современное состояние российской социально-экономической системы большинством исследователей характеризуется как переходное. В этом отношении можно предложить более широкую трактовку перехода в контексте мировых трансформационных процессов, подчеркивая, что он осуществляется не к некой абстрактной рыночной экономике, а в рамках конкретного этапа ее развития. Рассмотрение с позиций постфордистских концепций еще целого ряда конкретных проблем, актуальных для России (глобализация, политика неолиберализма, изменение роли государства и т. п.), также может дать интересные результаты.

\section{Краткая библиография}

Буайе Р. Теория регуляции. Критический анализ. М.: Научно-издательский центр «Наука для общества», РГГУ, 1997.

Меньшиков С.М., Клименко Л.А. Длинные волны в экономике. М.: Международные отношения, 1989.

${ }^{54}$ Б. Джессоп даже предпринял попытку создания целостной теории государства [См.: Jessop, B. State Theory. Putting the Capitalist State in its Place. Cambridge: Polity Press, 1994].

${ }^{55}$ Cм.: Jessop, B. Regulation Theories in Retrospect and Prospect, Economy and Society (May 1990). Vol. 19, No. 2; Jonnson, I. Regimes of Accumulation, Microeconomies and Hegemonic Politics, Capital and Class (1993). No. 50; Friedman, A. Microregulation and Post-Fordism: Critique and Development of Regulation Theory, New Political Economy (2000). Vol. 5, No. 1; и др.

${ }^{56}$ См. например: Peck, J., and A. Tickell. Searching for New Institutional Fix. P. 286.

57 Некоторые авторы прямо указывают на то, что советская система строилась на фордистских принципах, или даже говорят о ней как об «апогее фордизма» [См.: Murrey, R. Life after Henry Ford, Marxism Today (October 1988). P. 9]. 
Полетаев А.В., Савельев И.М. Циклы Кондратьева и развитие капитализма. М.: Наука, 1993.

Форд Г. Моя жизнь. Мои достижения. М.: Финансы и статистика, 1989.

Шевчук A.B. Постфордистские теории // Российский экономический журнал, 1999. №4.

Шевчук A.B. Постфордистские концепции (критический анализ). Казань, 2000.

Aglietta, M. A Theory of Capitalist Regulation: The US Experience. L.: New Left Books, 1979.

Amin, A. (ed.). Post-Fordism. Oxford: Basil Blackwell, 1994.

Dosi, G. (ed.). Technical Change and Economic Theory. L.: Frances Pinter, 1988.

Friedman A. Microregulation and Post-Fordism: Critique and Development of Regulation Theory, New Political Economy (2000). Vol. 5. No. 1.

Gramshi, A. Americanism \& Fordism, in his: Selections from Prison Notebooks. L.: Laurence \& Wishart, 1971.

Hall, S., and M. Jaques. New Times. L.: Lowrence \& Wishart, 1989.

Harvey, D. The Condition of Postmodernity: An Enquiry into the Origins of Cultural Change. Oxford: Blackwell, 1989.

Hollingsworth, J.R., and R. Boyer (eds.) Contemporary Capitalism. The Embeddedness of Institutions. Cambridge: Cambridge University Press, 1997.

Jessop, B. Regulation Theories in Retrospect and Prospect, Economy and Society (May 1990). Vol. 19, No. 2.

Kumar, K. From Post-Industrial to Post-Modern Society: New Theories of the Contemporary World. Oxford: Blackwell, 1995.

Lipietz, A. Mirages and Miracles: the Crisis of Global Fordism. L.: Verso, 1987.

Lipietz, A. Towards a New Economic Order: Post-Fordism, Ecology and Democracy. Cambridge: Polity Press, 1993.

Massey, D., and J. Allen (eds.). The Economy in Question. L.: Sage, 1994.

Piore, M., and C.Sabel. The Second Industrial Divide. N.Y.: Basic Books, 1984.

Sayer, A., and R. Walker. The New Social Economy: Reworking the Division of Labor. Oxford: Blackwell, 1992.

Scott, A. New Industrial Spaces: Flexible production Organisation \& Regional Development in North America and Western Europe. L.: Pion, 1988.

Tickell, A., and J. Peck. Accumulation, Regulation and the Geographies of Post-Fordism: Missing Links in Regulationist Research, Progress in Human Geography (1992). Vol. 16, No. 2.

Williams, K., Cutler, T., William, J., and C. Haslam, C. The End of Mass Production?, Economy and Society (1987). No. 16.

Wood, S. (ed.) The Transformation of Work: Skill, Flexibility and Labor Process. L.: Routledge, 1992. 


\title{
Новые переводы
}

$\boldsymbol{V R}$ Предлагается первая часть одного из основополагающих текстов Карла Поланьи о двух значениях «экономического». Безусловно, Поланьи является одной из классических и широко цитируемых фигур в экономической социологии. Ныне наблюдается своего рода ренессанс его трудов и в европейских странах, и в США. Так, в 2001 г. вышло новое издание его основной книги «Великая трансформация» с предисловиями Дж. Стиглица и Фреда Блока. В России же Поланьи пока не столь широко известен. Хотя уже изданы, по крайней мере, два перевода из его наследия (в журнале THESIS и книге «Неформальная экономика» под ред. Т. Шанина). Что же касается «Великой трансформации», то ее объявленный перевод все никак не завершится. Полный перевод текста, предлагаемого в данном номере, увидит свет позднее - в рамках подготавливаемой нами хрестоматии «Западная экономическая социология».

\section{ЭКОНОМИКА КАК ИНСТИТУЦИОНАЛЬНО ОФОРМЛЕННЫЙ ПРОЦЕСС ${ }^{1}$}

\section{Карл Поланьи}

\author{
Перевод М.С. Добряковой \\ Научное редактирование - В.В. Радаев
}

Основная задача данной главы - определить значение термина «экономический», которое можно было бы использовать во всех социальных науках.

Подобные попытки должны начинаться с простого признания того факта, что применительно к человеческой деятельности термин «экономический» используется в двух значениях, имеющих разные корни. Мы будем называть их содержательным и формальным значениями.

Содержательное значение [substantive meaning] «экономического» вытекает из факта зависимости человека от природы и других людей. Оно характеризует его взаимоотношения с природным и социальным окружением, которые обеспечивают ему средства удовлетворения материальных потребностей.

Формальное значение [formal meaning] термина «экономический» основывается на логическом характере связи между целями и средствами, являемой в таких понятиях, как «экономичный» или «экономить» [economical, economizing]. Оно подразумевает конкретную ситуацию выбора, а именно: выбора между различными способами использования средств, порождаемого их ограниченностью. Если правила, определяющие выбор средств, мы называем логикой рационального действия, то можем обозначить этот вариант логики новым термином - «формальная экономическая теория» [formal economics].

Два исходных значения [root meanings] понятия «экономический», - содержательное и формальное, - не имеют между собой ничего общего. Первое проистекает из факта,

${ }^{1}$ Polanyi, K., Arensberg, C., and H. Pearson. Trade and Market in the Early Empires; Economies in History and Theory. Glencoe, Ill.: Free Press, 1957.

2 Мы благодарим А.Б.Гофмана за консультации и помощь при составлении комментариев. 
второе - из логики. Формальное значение подразумевает некий набор правил, касающихся выбора между альтернативными способами использования ограниченных средств. Содержательное значение не предполагает ни выбора, ни ограниченности средств. Существование [livelihood] человека может включать или не включать необходимость выбора. Если же человек оказывается перед выбором, последний отнюдь не обязательно вызван ограничивающим эффектом «скудости» средств: ведь некоторые из наиболее важных физических и социальных условий существования людей, такие, как наличие воздуха и воды или любовь матери к ребенку, как правило, не носят ограничивающего характера. Непреложность формального значения отлична от содержательного значения так же, как сила логического умозаключения отлична от силы земного притяжения. Законы первого - это законы разума; законы второго суть законы природы. Едва ли можно придумать значения, более далекие друг от друга; семантически они находятся на противоположных полюсах.

Мы предполагаем, что только содержательное значение «экономического» способно порождать концепции, необходимые социальным наукам для эмпирического исследования всех типов хозяйства прошлого и настоящего. Следовательно, общая схема анализа [frame of reference], которую мы пытаемся выстроить, требует рассмотрения предмета в терминах содержательного определения. И сразу же на нашем пути возникает затруднение, проистекающее из бесхитростного переплетения двух значений «экономического» - содержательного и формального. Подобное смешение значений, конечно же, не столь страшно, - если только мы помним об ограничениях, которые оно накладывает. Однако в распространенном ныне понятии «экономический» происходит смешение значений, предполагающих «существование» [subsistence] и «дефицит» [scarcity], при этом не осознается в полной мере вся опасность для мышления, которая таится в подобном смешении.

Эта комбинация терминов возникла вследствие логически случайных обстоятельств. В последние два столетия в Западной Европе и Северной Америке сложилась такая организация человеческого существования, при которой особенно значимыми оказались правила выбора. Эта форма экономики основывалась на системе ценообразующих рынков [price-making markets]. Поскольку акты обмена при такой системе предполагают, что их участники осуществляют выбор по причине ограниченности средств, то вся система могла быть сведена к модели, которая использует методы, основанные на формальном значении «экономического». Пока экономика контролируется такой системой, формальное и содержательное значения экономического на практике совпадают. Обыватели приняли это смешанное понятие как само собой разумеющееся; такие мыслители, как А. Маршалл, В. Парето, Э. Дюркгейм также придерживались его. Только у К. Менгера в его посмертно опубликованной работе этот термин подвергается критике. Однако ни Менгер, ни позднее М. Вебер и Т. Парсонс не понимали всей значимости этого различения для социологического анализа. Ведь кажется, что нет серьезного основания для разграничения двух значений одного термина, которые, как мы уже сказали, почти совпадали на практике.

Хотя подобное разведение двух значений «экономического» в обыденной речи выглядело бы чистым педантизмом, их переплетение в одном понятии, тем не менее, превратилось в методологическое препятствие для социальных наук. Экономическая теория, естественно, стала исключением, поскольку в условиях рыночной системы предлагаемые ею термины оказывались достаточно близкими к реальности. Однако антрополог, социолог или историк, каждый со своих позиций изучавшие место экономики в человеческом обществе, сталкивались с огромным разнообразием институтов, отличных от институтов рынка, в которых было укоренено существование 
человека. И разрешить эти проблемы посредством аналитического метода, разработанного для особой формы экономики, зависящей от наличия специфических рыночных элементов, было невозможно ${ }^{3}$.

Эти выкладки очерчивают общие контуры наших дальнейших рассуждений.

Мы начнем с более тщательного анализа понятий, производных от двух значений «экономического», постепенно продвигаясь от формального к содержательному значению. Представляется, что это позволит на эмпирическом уровне описать хозяйства, - включая первобытные и древние формы, - в соответствии со способом институциональной оформленности экономического процесса. В качестве контрольных примеров мы рассмотрим три института: торговли, денег и рынка. Прежде они концептуализировались только с позиций формального определения, и, следовательно, любые пути к их анализу, кроме рыночного, были отрезаны. Рассмотрение же этих институтов в русле содержательного значения экономического должно приблизить нас к построению искомой универсальной схемы анализа.

\section{Формальное и содержательное значения «экономического»}

Рассмотрим формальные понятия и прежде всего то, как логика рационального действия порождает формальную экономическую теорию, а последняя в свою очередь создает условия для экономического анализа.

Рациональное действие определяется здесь как выбор средств по отношению к цели. Средства - это все, что может служить достижению цели, посредством ли законов природы или правил игры. Таким образом, «рациональное» не характеризует ни цель, ни средства, но, скорее, выражает соответствие средств целям [relating of means to ends]. Например, мы не говорим о том, что желание жить - более рационально, нежели желание умереть. Или же, что при желании жить более рационально стремиться продлить свою жизнь научными средствами, нежели с помощью суеверий. Какой бы ни была цель, рациональным является сообразный ей выбор средств. Что же касается собственно средств, то было бы нерационально прибегать к тому, во что человек не верит. Так, для самоубийцы рационален выбор средств, которые приведут его к смерти, и если этот человек верит в черную магию, - заплатить колдуну, чтобы тот помог это устроить.

Следовательно, логика рационального действия применима ко всем мыслимым средствам и целям, охватывающим чуть ли не бесконечное множество человеческих интересов. В разных сферах - будь то шахматы или техника, религиозная жизнь или философия - цели могут варьироваться от обыденных вопросов до самых сложных и трудноразрешимых проблем. Аналогично и в экономике: цели могут варьироваться от сиюминутного утоления жажды до стремления достичь почтенного возраста в добром

\footnotetext{
${ }^{3}$ Некритическое употребление смешанного понятия «экономический» привело к тому, что можно назвать «экономистическим заблуждением» [economistic fallacy]. Оно состоит в искусственном отождествлении экономики с еe рыночной формой. От Д. Юма и Г. Спенсера до Ф. Найта и Ф. Нортропа социальная мысль страдала от этого ограничения, стоило ей подойти к изучению хозяйства. Эссе Л. Роббинса, хотя и полезное для экономистов, окончательно исказило эту проблему [Robbins 1932]. В сфере антропологии недавно изданная работа М. Херсковица [Herskovits 1952] - своего рода продолжение его первой попытки рассуждений в этом направлении, предпринятой в 1940 г.
} 
здравии, как будут различны и средства их достижения, это могут быть соответственно стакан воды, вера в дочернюю и сыновнюю заботу или жизнь на свежем воздухе.

Если исходить из того, что выбор вызван ограниченностью средств, то логика рационального действия превращается в вариант теории выбора, который мы и называем формальной экономической теорией. Логически она еще не связана с понятием человеческого хозяйства, однако уже приблизилась к нему на один шаг. Как мы уже говорили, формальная экономическая теория описывает ситуацию, возникающую в результате ограниченности средств. Это так называемый постулат дефицита [scarcity postulate]. Он предполагает, во-первых, ограниченность средств и, во-вторых, то, что ситуация выбора порождается именно этой ограниченностью. Недостаточность средств по отношению к целям определена при помощи простой операции «целевого использования средств» [earmarking], показывающей возможность того или иного действия. Для того, чтобы недостаточность средств вела к ситуации выбора, этих средств должно быть несколько. То же относится и к целям - нужны, по крайней мере, две цели, выстроенные в порядке предпочтения. Оба эти условия являются фактами действительности, и не имеет значения, коренится ли причина использования средств каким-то определенным способом в традициях или технологии; то же касается и ранжирования целей.

Операционализировав таким образом понятия выбора, ограниченности и дефицита, мы сразу замечаем, что возможны выбор средств без ограниченности последних, равно как и ограниченность средств в отсутствие всякого выбора. Выбор может быть предпочтением правильного неправильному (нравственный выбор) или ситуацией, когда мы оказываемся на перепутье и к нашей цели ведут несколько путей, имеющих сходные достоинства и недостатки (операциональный выбор [operationally induced choice]). В обоих случаях изобилие средств не только не облегчает проблему выбора, но, скорее, усложняет ее. Разумеется, практически во всех сферах рационального действия проблема ограниченности средств может возникнуть или нет. Отнюдь не вся философия построена на творческом воображении, она может стремиться и к сокращению числа исходных посылок. Или же, возвращаясь к сфере человеческого существования: для одних цивилизаций ситуации недостатка средств являются скорее исключением, нежели правилом, для других - это широко распространенное явление. В любом случае, наличие или отсутствие дефицита ресурсов является фактом, и не важно, вызвана ли такая ситуация природными условиями или человеческими действиями.

Наконец, обратимся к экономическому анализу. Эта дисциплина развилась из приложения формальной экономической теории к конкретному типу хозяйства рыночной системе. Хозяйство здесь воплощено в институтах, которые побуждают акты индивидуального выбора к образованию взаимозависимых движений, составляющих в итоге экономический процесс. Это достигается посредством общего распространения ценообразующих рынков. Все товары и услуги, включая рабочую силу, землю и капитал, могут быть куплены на рынке и получают, следовательно, свою цену. Все формы дохода - соответственно заработная плата, рента и проценты - извлекаются из продажи товаров и услуг и появляются лишь как различные элементы цены реализованного продукта. Общее определение покупательной способности как средства приобретения благ превращает процесс удовлетворения потребностей в использование ограниченных средств альтернативными способами посредством денег. Это означает, что и условия выбора, и его последствия поддаются количественному измерению в форме цен. Можно утверждать, что, приняв цену в качестве par excellence ${ }^{4}$ экономического факта,

\footnotetext{
${ }^{4}$ Преимущественно (франи.). Прим. перев.
} 
формальный подход предполагает, что хозяйство в целом обусловлено ситуациями выбора, которые возникают вследствие ограниченности средств. Понятийный аппарат, позволяющий описать такую ситуацию, и лежит в основе экономического анализа.

Отсюда вытекают и пределы, в рамках которых экономический анализ может быть эффективен как метод. Формальное значение «экономического» представляет хозяйство как последовательность актов экономии ресурсов [acts of economizing] - иными словами, как совокупность выборов, вызванных дефицитом средств. Хотя правила, управляющие подобными актами, носят универсальный характер, степень, в которой эти правила применимы к какому-то конкретному хозяйству, зависит от того, является ли в реальности данная экономика последовательностью таких актов. Чтобы обеспечить количественные результаты, акты перемещения и приобретения товаров, которые составляют экономический процесс, должны выступать как функции социальных действий по отношению к ограниченным средствам и должны быть ориентированы на итоговые цены. Такая ситуация возможна только в условиях рыночной системы.

В результате связь между формальной экономической теорией и человеческим хозяйством оказывается непрочной. За пределами системы ценообразующих рынков экономический анализ как метод исследования реального хозяйства чуть ли не полностью теряет свое значение. Наглядным подтверждением этому служит централизованное плановое хозяйство, основанное на нерыночных ценах.

Корни содержательного понятия «экономический» - в реальном хозяйстве. Вкратце (что может быть рискованным) его можно определить как институционально оформленный процесс взаимодействия между человеком и окружающей средой, ведущий к постоянному обеспечению материальных средств для удовлетворения потребностей. Удовлетворение потребностей «материально», если оно предполагает использование материальных средств для достижения целей; в случае таких конкретных физиологических нужд, как потребность в пище или жилье, используются лишь так называемые услуги.

Таким образом, хозяйство предстает как институционально оформленный процесс [instituted process]. И здесь мы сталкиваемся с двумя понятиями - «процесс» и «институциональная оформленность» [institutedness]. Посмотрим, что они могут добавить к нашей аналитической схеме.

«Процесс» предполагает анализ с позиций движения [motion]. Перемещения [movements] характеризуют место расположения [location] или акт присвоения [appropriation], или и то, и другое. Иными словами, материальные ресурсы могут менять свое положение, перемещаясь с места на место или переходя из рук в руки. Опять-таки эти совершено разные смены позиции могут происходить как вместе, так и порознь. Видимо, все возможные перемещения в рамках экономического процесса как природного и социального явления могут быть сведены к указанным двум видам перемещений.

Пространственные перемещения [locational movements] включают производство и транспортировку, для которых пространственное передвижение одинаково важно. Товары могут быть низшего или высшего порядка - в зависимости от их полезности для потребителя. Известный способ ранжирования товаров [order of goods] противопоставляет потребительские товары товарам для производителей в зависимости от того, удовлетворяют ли они ту или иную потребность напрямую или косвенным образом, т.е. в сочетании с другими товарами. Подобное движение элементов и составляет суть хозяйства в содержательном смысле, каким выступает производство. 
Перемещения путем присвоения [appropriative movements] охватывают то, что обычно называют товарным обращением и его администрированием. В первом случае это перемещение является результатом трансакций, во втором - распорядительских позиций [dispositions]. Соответственно трансакция - это перемещение из рук в руки путем присвоения, а распоряжение [disposition] есть одностороннее присвоение волею традиций или закона. В роли субъектов («рук») могут выступать общественные учреждения и службы, а также частные лица или фирмы; различие между ними состоит главным образом в их внутренней организации. Однако следует отметить, что в XIX в. трансакции ассоциировались, как правило, с «частными лицами», а распорядительские позиции - с общественными учреждениями.

Подобный выбор терминов подразумевает выведение ряда дальнейших определений. Социальную деятельность, пока она является частью процесса производства и транспортировки, можно называть экономической; институты можно называть экономическими - в зависимости от степени их сконцентрированности на такого рода деятельности; любые компоненты этого процесса можно рассматривать в качестве экономических элементов. Для удобства последние можно подразделить на экологические, технологические и социетальные в зависимости от того, относятся ли они преимущественно к окружающей среде, механическому оборудованию или человеческой сфере. Таким образом, при характеристике хозяйства как процесса, наша аналитическая схема обрастает рядом понятий - старых и новых.

Тем не менее, если мы сведем экономический процесс только к взаимодействию элементов механического, биологического или психологического свойства, он не достигнет уровня всеобщности. От него останется лишь остов, образованный процессами производства и транспортировки, а также перемещениями от одного владельца к другому [appropriative changes]. При отсутствии какого бы то ни было указания на социетальные условия, из которых вытекают мотивы индивидов, едва ли можно сказать, что именно поддерживает взаимозависимость и повторяемость перемещений, от которых зависят единство структуры и стабильность процесса в целом. Взаимодействующие элементы природной и человеческой сред не сложились бы в нечто цельное, не возникло бы структурного единства, о котором можно было бы сказать, что оно выполняет некую функцию в обществе или обладает собственной историей. Этому процессу не доставало бы тех самых качеств, которые и заставляют обыденное сознание и научное сообщество обратиться к проблемам человеческого существования как области, представляющей серьезный практический интерес, а также обладающей большим теоретическим и нравственным значением.

Отсюда следует исключительная важность институционального аспекта хозяйства. То, что на уровне процесса происходит между человеком и почвой при вспахивании земли

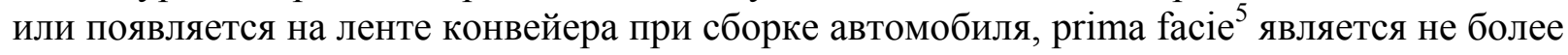
чем согласованными перемещениями живой и неживой материи. С институциональной точки зрения, это простое обозначение терминов - таких, как рабочая сила и капитал, ремесло и профсоюз, замедление и ускорение, распределение рисков и другие семантические единицы социального контекста. Например, выбор между капитализмом и социализмом подразумевает два различных пути институционального оформления [instituting] современной технологии в процессе производства. В сфере политики индустриализация отсталых стран опять-таки предполагает, с одной стороны, альтернативные методы ее осуществления, а с другой, - альтернативные пути

\footnotetext{
${ }^{5}$ На первый взгляд (лат.). Прим. перев.
} 
институционального оформления этих методов. Наше концептуальное разграничение чрезвычайно важно для понимания взаимозависимости технологии и институтов, равно как их относительной самостоятельности.

Институциональное оформление экономического процесса придает ему внутреннее единство и стабильность. Оно порождает структуру, наделенную в обществе конкретной функцией. Оно изменяет место экономического процесса в обществе, придавая тем самым бо́льшую значимость его истории. Оно концентрирует внимание на ценностях, мотивах и проводимой политике. Единство и стабильность, структура и функция, история и политика [policy] на операциональном уровне иллюстрируют наше утверждение о том, человеческое хозяйство - это институционально оформленный процесс.

В этом случае человеческое хозяйство укоренено в институтах, экономических и неэкономических, вплетено в них. Важно подчеркнуть включение сюда неэкономических элементов. Ведь религия или управление могут быть так же важны для структуры и функционирования хозяйства, как денежные институты или наличие машин и оборудования, облегчающих тяжелое бремя труда.

Таким образом, исследование изменения места хозяйства в обществе - это, по сути, исследование способов институционального оформления экономического процесса в разное время и в разных местах.

Для этого требуются особые исследовательские инструменты.

\section{Реципрокность, перераспределение и обмен}

Исследование институционального оформления реальных хозяйств [empirical economies] должно начинаться с анализа того, как эти хозяйства обретают внутреннее единство и стабильность, т.е. взаимозависимость и повторяемость их составных частей. Это достигается сочетанием очень немногих способов связи [patterns], которые можно назвать формами интеграции. Поскольку эти способы связи существуют бок о бок друг с другом на разных уровнях и в различных секторах экономики, зачастую невозможно выделить какой-либо из них в качестве доминирующего. Таким образом, все они должны использоваться для классификации реальных хозяйств в целом. Тем не менее, различаясь в зависимости от сектора и уровня хозяйства, формы интеграции являются сравнительно простым средством описания экономического процесса, привнося, таким образом, некую долю упорядоченности в его бесчисленные вариации.

На эмпирическом уровне такими основными способами связи являются реципрокность, перераспределение и обмен. Реципрокность [reciprocity] обозначает перемещения между соответствующими точками в симметричных группах; перераспределение [redistribution] представляет собой акты «стягивания» товаров центром с их последующим перемещением из центра; под обменом [exchange] подразумеваются встречные перемещения из рук в руки в условиях рыночной системы. Следовательно, реципрокность предполагает наличие симметрично расположенных групп [symmetrically arranged groupings]; перераспределение зависит от существования в группе определенной степени централизованности [centricity]; обмен, чтобы порождать интеграцию, предполагает наличие системы ценообразующих рынков. Очевидно, что различные способы интеграции требуют определенной институциональной поддержки.

Здесь будут нелишними некоторые пояснения. Термины «реципрокность», «перераспределение» и «обмен», с помощью которых мы характеризуем способы 
интеграции, часто используются для обозначения межличностных отношений. На первый взгляд может показаться, что формы интеграции попросту отражают совокупность соответствующих форм индивидуального поведения: там, где отношения между индивидами предполагают взаимность [mutuality], складывается реципрокная интеграция; там, где существует распределение чего-то между индивидами, возникает перераспределительная (редистрибутивная) интеграция; наконец, частые акты товарообмена [barter] между индивидами ведут к обмену как форме интеграции. Если бы это было так, то указанные нами способы интеграции представляли бы собой не более чем сумму соответствующих форм поведения на индивидуальном уровне. Чтобы уточнить свою позицию, мы утверждаем, что интегративный эффект обусловлен наличием определенных институциональных образований [arrangements] - таких, как симметричные организации, центры и рыночные системы соответственно. Однако такие образования, по всей видимости, являют собой простую совокупность тех самых частных способов связи, конечное действие которых они и призваны обусловливать. Важно подчеркнуть, что простая сумма индивидуальных поведенческих актов сама по себе не порождает такие структуры. Реципрокное поведение на уровне индивидов способно интегрировать хозяйство только при наличии симметрично организованных структур - таких, как симметричная система родственных групп. Однако система родства никогда не выступает просто как результат реципрокного поведения на уровне индивидов. То же относится и к перераспределению. Оно предполагает наличие в сообществе распределительного центра [allocative center]. При этом организация и обоснование деятельности такого центра не выступают просто как результат частых актов распределения благ между индивидами. Это же касается и рыночной системы. Акты обмена на уровне индивидов порождают цены только в том случае, если эти акты происходят в системе ценообразующих рынков, - т.е. в институциональной среде, которая нигде не формируется просто случайными актами обмена. Конечно же, мы не имеем в виду, что эти поддерживающие способы связи [supportive patterns] являются продуктом каких-то таинственных сил, действующих помимо отдельных индивидов. Мы просто хотим сказать, что в каждом конкретном случае социетальные последствия индивидуального поведения зависят от наличия определенных институциональных условий, и поэтому данные условия не складываются из актов индивидуального поведения. На первый взгляд кажется, что поддерживающий способ связи [supportive pattern] возникает как кумулятивный результат соответствующего типа индивидуального поведения, однако необходимые элементы его организации и обоснования обязательно привносятся и совершенно другими типами поведения.

Первым автором, обратившим внимание на фактическую взаимосвязь между реципрокным [reciprocative] поведением на межличностном уровне, с одной стороны, и определенными симметричными группами, с другой, был антрополог Ричард Турнвальд [Richard Thurnwald], описавший еще в 1915 г. систему заключения брака у народности банар в Новой Гвинее. Примерно десятилетие спустя Бронислав Малиновский, ссылаясь на Турнвальда, высказал предположение, что социально значимые акты реципрокного поведения, как правило, основываются на симметричных формах основной социальной организации. Его собственные описания системы родства и обмена согласно обычаю «кула» ${ }^{6}$ на Тробрианских островах подтверждают этот тезис. Малиновский развивает эту

${ }^{6}$ «Кула» - обычай жителей Тробрианских островов, состоящий в обмене дарами и имеющий статус священного. См. также: Уорнер У. Живые и мертвые. М.-СПб.: Университетская книга, 2000. С. 645. Прим. перев. 
мысль далее, рассматривая симметрию как лишь один из поддерживающих способов связи. Другими формами интеграции, помимо реципрокности, он называет перераспределение и обмен; аналогично в качестве примеров институциональной поддержки (помимо симметрии) он приводит также централизацию и рынок. Именно отсюда мы заимствуем наши формы интеграции и поддерживающей структурной связи.

Bсе это должно нам помочь объяснить, почему при отсутствии определенных институциональных предпосылок в экономической сфере межличностное поведение столь часто не приведут к ожидаемым социетальным эффектам. Только в симметрично организованной среде реципрокное поведение ведет к становлению сколь-либо значимых экономических институтов; только там, где существуют распределительные центры, индивидуальные акты распределения [acts of sharing] способны породить перераспределительную экономику; только при наличии системы ценообразующих рынков акты обмена между индивидами приводят к возникновению колеблющихся цен, интегрирующих экономику. В противном случае подобные акты товарообмена окажутся неэффективными и в результате станут происходить все реже и реже. Если же они всетаки будут повторяться случайным образом, то вызовут бурную эмоциональную реакцию, - как если бы в них было что-то неприличное или сродни предательству, ибо поведение в сфере торговли никогда не является эмоционально нейтральным и, значит, получает негативную оценку, стоит только преступить черту, обозначающую установленные порядки.

Вернемся теперь к формам интеграции.

Если некая группа вознамерится построить свои экономические отношения на реципрокной основе, для достижения своих целей она должна будет разбиться на подгруппы, члены которых смогут идентифицировать друг друга в качестве таковых. Члены группы $A$ смогут тогда установить отношения реципрокности со своими контрагентами в группе $B$, и наоборот. Однако симметричность не ограничивается подобным дуализмом. Три, четыре и более групп могут быть симметричны по двум или более осям. Кроме того, члены группы могут не вступать в реципрокные отношения друг с другом, однако иметь их определенными членами других групп. Например, на Тробрианских островах мужчина заботится о семье своей сестры, муж сестры в этом отношении ему не помогает. Если же этот мужчина женат, то ему помогает брат его жены, т.е. член третьей семьи, занимающий симметричную позицию.

Аристотель полагал, что каждому типу сообщества (koinōnia) соответствует определенный тип привязанности между его членами (philia), выражающийся в реципрокности (antipeponthos). Это касалось и наиболее устойчивых постоянных сообществ (таких, как семья, племя или город-государство), и тех, что выступали составными частями или подчиненными элементами первых. В нашей терминологии это означает, что крупные сообщества имеют тенденцию вырабатывать многоуровневую симметрию отношений [multiple symmetry], в соответствии с которой реципрокное поведение станет развиваться реципрокное поведение в сообществах низшего порядка. Чем более близкими друг другу чувствуют себя члены крупного сообщества, тем более они будут склонны переводить на реципрокную основу конкретные отношения, ограниченные во времени, пространстве или как-либо иначе. Родство, соседство, тотем являются наиболее постоянными и полными [comprehensive] группами; внутри них добровольные и полудобровольные объединения военного, профессионального, религиозного или социального характера создают условия (по крайней мере, временные или применительно к данному месту или типичной ситуации), для формирования симметричных групп, члены которых связаны теми или иными взаимными узами. 
Реципрокность как форма интеграции становится значительно более мощной в силу своей способности использовать перераспределение и обмен в качестве вспомогательных методов. Она может достигаться посредством распределения трудового бремени в соответствии с определенными правилами перераспределения (например, при выполнении того или иного действия «по очереди»). Аналогично реципрокность иногда достигается посредством обмена в установленных пропорциях [at set equivalences], который выгоден партнеру, испытывающему необходимость в чемлибо, - это один из фундаментальных институтов обществ Древнего Востока. В результате в нерыночных экономиках две формы интеграции - реципрокность и перераспределение - работают вместе.

Отношения перераспределения складываются в группе в той степени, в какой распределение товаров в ней сосредоточено в одних руках и подчиняется обычаю, закону или ситуативному решению центра. Иногда они включают физическую централизацию благ, предполагающую их хранение-и-перераспределение [storage-cumredistribution]; в других случаях «сбор» происходит не в физической форме, а только на уровне смены владельца [appropriational] - иными словами, передаются права распоряжения физическим расположением товаров. Перераспределение происходит по многим причинам на всех этапах цивилизации, начиная от первобытных охотничьих племен до крупных складских систем древнего Египта, Шумера, Вавилона или Перу. В крупных странах необходимость системы перераспределения может вызываться почвенными и климатическими различиями; в других обстоятельствах перераспределение обусловлено разрывом во времени между сбором урожая и его потреблением. В случае с охотой любой иной метод распределения привел бы к дезинтеграции племени или общины, поскольку необходимого результата здесь можно достичь только при условии «разделения труда». Перераспределение покупательной способности может выступать как самоценность, например, в русле провозглашенных общественных идеалов, - как это происходит в современном государстве благосостояния. Принцип остается тем же: сначала все собирается в центре, а затем распределяется из центра. Отношения перераспределения могут существовать и в меньших группах внутри общества - таких, как домохозяйство или феодальное поместье - независимо от того, каким способом интегрировано хозяйство в целом. Наиболее известные примеры такого перераспределения - центрально-африканский крааль, еврейское патриархальное домохозяйство, греческое поселение ${ }^{7}$ времен Аристотеля [estate], римское семейство (familia), средневековый манор ${ }^{8}$ или типичное крупное крестьянское домохозяйство до появления общей практики вывоза зерна на рынок. Однако только при сравнительно развитой форме сельскохозяйственного общества система крупных домохозяйств такого рода становится возможной, а впоследствии и обычной формой хозяйства. До этого этапа широко распространенная «малая семья» не была институционализирована экономически, за исключением некоторых элементов приготовления еды; использование же пастбищ, земли, скота по-прежнему

\footnotetext{
${ }^{7}$ Такое поселение занимает промежуточное положение между семьей и полисом. Прим. перев.

8 Манор - название феодальной вотчины в средневековой Англии. Он возник еще до нормандского завоевания Англии в 1066 г. С распространением внутри страны манор состоял из домена - собственно хозяйства лорда - и земли держателей-крепостных (вилланов) и свободных (фригольдеров). К манору относились и общинные угодья, считавшиеся уже собственностью лорда. Управление манором осуществляли министериалы лорда (так называемые стюарды). В XVIII в. манор окончательно исчезает // http://www.edic.ru/history/art/art_1320.html Прим. перев.
} 
регулировалось перераспределительными или реципрокными методами за рамками одной семьи.

Перераспределение также служит интеграции групп на всех уровнях, независимо от их устойчивости во времени - это могут быть и государство, и единицы переходного характера. Здесь, как и в случае с реципрокностью, чем более тесны связи в рамках более крупной единицы, тем более разнообразны подгруппы, в которых может эффективно действовать система перераспределения. Платон полагал, что оптимальное число граждан в государстве - 5040 человек. Эту цифру можно делить 59 различными способами, включая деление на начальные десять чисел. Он объяснял, что такая численность населения предоставляет наиболее широкие возможности при расчете налогов, формировании групп для деловых трансакций, для выполнения военных и прочих обязанностей «по очереди» и т.д.

Чтобы выступать в качестве формы интеграции, обмен должен поддерживаться системой ценообразующих рынков. Следует различать три типа обмена: простое перемещение товаров в пространстве «из рук в руки» (операциональный обмен); обмен между их владельцами на основе фиксированного эквивалента (обмен на основе решения) и обмен на основе торга (интегративный обмен). Если действует обмен на основе фиксированных ставок [decisional exchange], хозяйство интегрируется не рыночным механизмом, а факторами, фиксирующими эти ставки. Даже ценообразующие рынки выступают в качестве интегрирующего механизма, только если они связаны между собой в систему, при которой действие цен распространяется и на другие рынки помимо тех, которые они затрагивают непосредственно.

Торг [higgling-haggling] совершенно справедливо считается основой поведения в сфере заключения сделок [bargaining]. Для того, чтобы обмен выступал как интегрирующий механизм, поведение партнеров должно быть ориентировано на установление цены, приемлемой для каждого из них. Такое поведение в корне отличается от обмена на основе фиксированных цен. Видимо, различие проистекает из неоднозначности термина «выгода» [gain]. Обмен при фиксированных ценах предполагает выгоду хотя бы для одной из задействованных в нем сторон; обмен на основе колеблющихся цен имеет целью выгоду, которую можно получить только на основе выраженно антагонистичных отношений между партнерами. Элемент антагонизма, в сколь бы мягкой форме он ни проявлялся, непременно сопутствует данному типу обмена. Ни одно сообщество, стремящееся сохранить чувство солидарности в своих членах, не может позволить развиваться скрытой враждебности между ними (например, по поводу пищи - вопроса, столь важного для человеческого существования и, следовательно, способного вызывать сильное напряжение). Отсюда - повсеместный запрет трансакций, ориентированных на получение выгоды в отношении еды и продуктов питания в первобытных и древних обществах. Очень широко распространенный запрет на торги по поводу пищи автоматически исключает ценообразующие рынки из группы ранних институтов.

Интересна традиционная классификация хозяйств, в грубом приближении похожая на классификацию в соответствии с господствующими формами интеграции. То, что историки привыкли называть «экономическими системами», видимо, вполне вписывается в эту модель. Господство той или иной формы интеграции отождествляется здесь со степенью, в какой распоряжение землей и трудом в обществе осуществляется на основе именно этой формы интеграции. Так называемое общество дикарей [savage society] характеризуется интеграцией земли и труда в хозяйство узами родства. В феодальном обществе судьбы земли и труда на ней определяются отношениями между феодалом и вассалом. В ирригационных обществах земля распределялась и иногда 
перераспределялась, как правило, церковью или правящей династией, то же происходило c рабочей силой - по крайней мере, с зависимым трудом. Постепенное подчинение хозяйства рынку можно проследить, если обратить внимание на то, как земля и пища мобилизовались посредством обмена, а рабочая сила превращалась в товар, который свободно покупался на рынке. Это помогает объяснить значение традиционной для марксизма, однако исторически не оправдавшей себя теории стадий (формаций) рабства, крепостничества, наемного труда. Подобная классификация строится на убеждении, что тип хозяйства задается характером труда. Однако едва ли стоит полагать, будто в этом отношении характер интеграции земельных наделов в хозяйстве менее важен.

В любом случае та или иная форма интеграции не отражает исторические «стадии» развития. Формы интеграции не предполагают никакой последовательности во времени. Наряду с одной господствующей формой интеграции могут существовать несколько подчиненных форм, сама же господствующая форма также может временно отойти на задний план, а затем вернуться. В родовых общинах действуют реципрокность и перераспределение, в то время как архаичные общества основываются, главным образом, на перераспределении (хотя в какой-то степени могут использовать и отношения обмена). Реципрокность, играющая главную роль в некоторых меланезийских обществах, в редистрибутивных империях древности занимает хотя и значимое, но подчиненное положение: международная торговля (основанная на системе приносимых и ответных даров) в значительной мере организована по принципу реципрокности. Например, в XX столетии во время войны этот принцип был введен вновь и широко использовался под названием ленд-лиза государствами, в которых в невоенной ситуации доминировали отношения рынка и обмена. Перераспределение основной принцип отношений в родовой общине и древнем обществе, по сравнению с которым обмен играет лишь второстепенную роль, - приобрело огромное влияние в поздней Римской империи и постепенно набирает силу сегодня в некоторых индустриальных государствах (крайний случай - Советский Союз). И наоборот, прежде в истории человечества рынки не раз играли заметную роль в экономике, хотя никогда ни с точки зрения территориального охвата, ни с точки зрения полноты институционального оформления - эта роль не была сопоставима с их ролью в XIX в. Однако и здесь также наблюдаются заметные перемены. В XX столетии, с падением золотого стандарта началось сокращение роли рынков в мировой экономике по сравнению с XIX в.; этот поворот, кстати, возвращает нас к исходной точке - к более ясному пониманию неадекватности наших рыночно ориентированных определений, слишком узких для социального исследования экономического поля.

\section{Примечания}

Herskovits, M. The Economic Life of Primitive Peoples. N.Y.: A.A.Knopf, 1940.

Herskovits, M. Economic Anthropology: A Study in Comparative Economics. N.Y.: A.A.Knopf, 1952.

Robbins, L. An Essay on the Nature and Significance of Economic Science. L.: Macmillan, 1932. 


\section{Взгляд из регионов}

$\boldsymbol{V} \boldsymbol{R}$ Мы размещаем работу Ольги Бредниковой и Олега Паченкова (Центр независимых социологических исследований, Санкт-Петербург). Работа выполнена в рамках проекта ЦНСИ «Кавказцы в российском городе: стратегии интеграции на фоне ксенофобии» (1997-1999 гг.) и посвящена исследованию социальных сетей, сформированных экономическими мигрантами. Авторы размышляют об этничности «этнической экономики». Результаты исследования были представлены на международном семинаре «Этничность и экономика в постсоциалистическом пространстве» (Санкт-Петербург, 2000 г.), материалы которого вошли в одноименный сборник [Под ред. Бредниковой О., Воронкова В., Чикадзе Е. СПб.: ЦНСИ, 2000;

http://www.indepsocres.spb.ru/sbornik8/8r bred.htm]. Статья публикуется с любезного согласия авторов.

\section{ЭТНИЧНОСТЬ «ЭТНИЧЕСКОЙ ЭКОНОМИКИ» И СОЦИАЛЬНЫЕ СЕТИ МИГРАНТОВ}

\author{
Ольга Бредникова \\ Центр независимых социологических \\ исследований
}

Email: bred@indepsocres.spb.ru

\author{
Олег Паченков \\ Центр независимых социологических \\ исследований \\ Email: oleg@indepsocres.spb.ru
}

В данной статье на примере исследования принципов формирования социальных сетей экономическими мигрантами мы попытаемся критически рассмотреть существующие концепции и поразмышлять об этничности «этнической экономики».

Объектом нашего исследования стали экономические мигранты с Кавказа и Средней Азии, торгующие на рынках Петербурга. Для того, чтобы лучше понять жизненные стратегии и механизмы интеграции мигрантов, мы исследовали людей, проживающих в Петербурге не более трех лет. Учитывая специфику объекта, мы полагаем, что единственно возможный и адекватный метод исследования - участвующее наблюдение. Мы наблюдали и, насколько было возможно, участвовали в различных сферах каждодневной жизни наших информантов (работа на рынке, организация обыденной жизни, взаимоотношения с представителями государства и т.д.). При этом мы не просто участвовали и наблюдали происходящие события, но и старались получить интерпретацию происходящего со стороны его участников.

\section{Этническая экономика}

Этническая экономика - концептуально разработанная тема в социологической дискуссии на Западе ${ }^{1}$. Существуют несколько классификаций теоретических подходов к анализу

${ }^{1}$ В России данная тема мало разработана. Нам известны лишь публикации В.Дятлова [исторический анализ «торговых меньшинств», 1996], В.Радаева [обзор западной дискуссии, 1993], А.Снисаренко [1999] и В. Ильина [1994] (см. также публикации в 
этого феномена, варианты самых распространенных можно найти в работах Лайта [Light 1984] и Уолдингера [Waldinger 1986] ${ }^{2}$. Сегодня практически все концепции этнической экономики ${ }^{3}$ исходят, главным образом, из того, что мигранты, которые в принимающей стране становятся меньшинством, попадают в особую ситуацию. Они одновременно оказываются в «ущемленном» [disadvantage] положении меньшинства и в то же время имеют в своем распоряжении дополнительные ресурсы, которые принято называть «этническими». Согласно Лайту, этническими являются ресурсы, которые основаны на идентификации человека с определенным этническим сообществом [Light 1986: 21].

Использование «этнических» ресурсов позволяет мигрантам не только найти жилье, обустроиться и т.д., но также определяет их экономические стратегии. Этот феномен принято называть «этнической экономикой»: «Экономика является этнической, если в ней участвуют представители одной этнической груnпы [co-ethnics]»[Light, Karageorgis 1994: 649]. Предполагается, что, будучи этническим меньшинством, люди имеют возможность объединиться на основе общей (разделенной) этничности и организовать совместный бизнес. Также предполагается, что они доверяют друг другу лишь потому, что принадлежат к общей этнической группе. Доверие, основанное на разделенной этнической идентичности, позволяет сформировать «этнические» социальные (экономические) сети, сокращает возможные трансакционные издержки, связанные с недоверием (например, излишним становится использование посредников, выступающих гарантами в бизнесе) [Light 1986: 22].

Таким образом, существующее понимание «этнической экономики» в значительной степени опирается на концепт этничности и исходит из этнической принадлежности вовлеченных в нее индивидов. При этом совершенно неясно, 1) каким образом и кем этническая принадлежность индивидов определяется и 2) каково влияние этнической принадлежности на собственно экономическое поведение этих индивидов.

Что касается ответа на первый вопрос, то, как следует из некоторых исследований, этническая принадлежность индивидов определяется самим исследователем на основании его «естественных установок» (термин Г. Гарфинкеля) и «объективных» критериев. Такой подход, на наш взгляд, во-первых, основывается не на научном, а на обыденном знании, во-вторых, не учитывает дискуссии о характере и природе этничности [см., например, дискуссию: Воронков 1998; Винер 1998; Тишков 1997 и пр.].

Исследователи, исходящие из процитированного выше определения этнической экономики, не ставят перед собой вопроса о влиянии этничности на экономические

данном сборнике). Поэтому здесь мы ссылаемся в основном на работы западных социологов.

${ }^{2}$ Мы оставляем в стороне их обсуждение, поскольку это уведет нас от основной темы данной работы. Мы также позволим себе не принимать в расчет устаревшие, на наш взгляд, подходы (например, культурно-исторический).

${ }^{3}$ Согласно Бонацич и Модел [Bonacich \& Model 1980], этническая экономика включает в себя: а) этническую самозанятость; б) этнических хозяев-нанимателей; в) этнических наемных. Мы будем использовать понятие этнической экономики именно в этом значении. Под этническим предпринимательством будет пониматься собственно «этническая самозанятость» любого масштаба, от индивидуального или семейного частного предприятия до предприятий с наемными рабочими; термин этнический бизнес мы употребляем как синоним этнического предпринимательства. 
действия индивида. Для них очевидно, что если мигрант «китаец» («объективный» признак), то он будет вести себя как китаец и в экономике.

Мы в своем исследовании исходили из «понимающего» определения «этнической экономики» как экономики, в которую вовлечены индивиды, субъективно осмысленно ориентирующиеся в своем экономическом поведении на собственную субъективно понимаемую этничность и этничность тех, с кем они взаимодействуют ${ }^{4}$. На основании подобного подхода мы ставим под сомнение тезис о существовании «этнической экономики» в среде исследованных нами мигрантов ${ }^{5}$. Исследование показало, что ориентация на этничность носит ситуативный характер и не является определяющей в выборе жизненных (в том числе трудовых) стратегий. В реальной жизни, в реальном бизнесе помогают и доверяют друг другу не «со-ethnics», а мигранты, часто принадлежащие к различным этническим группам, помогают друг другу «друзья», «коллеги», «соседи» и т.п. Это означает, что разделенная этничность, «объективно» присутствующая с точки зрения стороннего наблюдателя, в действительности не является характеристикой, на которую мигранты субъективно ориентируются в своих экономических действиях.

\section{Социальные сети экономических мигрантов}

Оставив в стороне этничность, мы попытались исследовать действительные механизмы, обеспечивающие выживание мигрантов в условиях «ущемленного» [disadvantage] положения. Мигранты испытывают значительный дефицит капиталов, в том числе капитала социальных сетей. Под социальными сетями мы, вслед за рядом авторов, понимаем «стабильные модели непосредственного взаимодействия между людьми» [Рона-Тас 1999: 396]. В ситуации социального вакуума мигранты начинают активно выстраивать социальные сети, наращивая таким образом социальный капитал. Новые социальные связи позволяют мигрантам обустраиваться: находить жилье, работу, устраивать детей в школы, пользоваться услугами медицинских институтов и т.п. В экономической жизни социальные сети открывают мигрантам доступ к финансам, рабочим местам и, что особенно важно, к информации. По мнению большинства западных исследователей миграции, неформальные отношения на базе социальных сетей, вопервых, являются одним из важнейших факторов, определяющих образ жизни мигрантских сообществ, во-вторых, составляют основное преимущество мигрантов перед местным большинством в сфере экономики [Waldinger 1986].

Мы выделили пять основных факторов, определяющих, на наш взгляд, организацию социальных сетей мигрантов:

- легкость (простота, беспроблемность);

4 Под этничностью мы здесь, вслед за Вебером и другими авторами, понимаем а) субъективную веру в общее происхождение и общность [Weber 1999: 19], б) процесс по ее интерсубъективному конструированию [Воронков, Освальд 1998: 12].

${ }^{5}$ В этом наша точка зрения полностью противоположна позиции Снисаренко, который, используя теоретический аппарат западных концепций этнического предпринимательства, описывает «азербайджанскую общину в Петербурге» [см.: Снисаренко 1999]. 
- рациональность (выгода);

- доверие;

- давление извне (вытеснение);

- пространство.

Эти факторы были выделены при анализе социальных действий и взаимодействий мигрантов ${ }^{6}$. Принципом их выделения была формулировка «взаимодействуют с тем, с кем...» (легко, выгодно, кому доверяешь, с кем пересекаешься в пространстве...). По нашему мнению, именно эти факторы структурируют деятельность мигрантов, ложатся в основу формирования и использования мигрантами социальных сетей. Опишем их более подробно.

Легкость/сложность. Мигранты взаимодействуют с теми, с кем проще, чьи действия и поведение понятны и предсказуемы. Здесь основное значение имеет язык: плохое знание мигрантами русского языка препятствует взаимодействию мигрантов с местным населением. Азербайджанец будет сотрудничать и/или общаться с другим азербайджанцем не на том основании, что они оба азербайджанцы, но потому, что им легко понимать друг друга, в том числе потому, что они говорят на одном языке. Вместе с тем, если возникает необходимость (как правило, экономического характера), мигранты, говорящие на разных языках, вступают во взаимодействие: мы сами наблюдали, как азербайджанцы и таджики, таджики и молдаване работали вместе как напарники ${ }^{7}$. Они общаются между собой на русском языке, потому что русский является для них единственным общим языком, позволяющим осуществлять коммуникацию. Таким образом, хотя язык является одной из важнейших составляющих понятия «этническая группа» [Smith 1986: 27], не следует преувеличивать значение этнической компоненты. Мы склонны акцентировать практическую роль языка для мигрантов: не в качестве маркера социальных (этнических) границ, но в качестве инструмента коммуникации, необходимого для взаимодействия.

«Легкость» взаимодействия также может рассматриваться с точки зрения предсказуемости поведения. В представлении людей существуют культурные паттерны поведения. С одной стороны, знание этих паттернов обеими сторонами на практике облегчает взаимодействие со «своими». С другой стороны, представляется, что мнение о непредсказуемости и, следовательно, опасности, исходящей от представителей «чужой» культуры в силу «непостижимости» их культурных паттернов поведения, зачастую слишком преувеличено. При внимательном наблюдении выясняется, что гораздо большую роль, нежели воображаемая принадлежность к той или иной культуре, играет образование человека, «стаж» мигранта, городская или сельская социализация и др. Образованному азербайджанцу - профессору, знатоку и преподавателю азербайджанской культуры, много лет живущему в Петербурге, значительно проще найти «общий язык» с другим петербуржским профессором, нежели с недавним мигрантом из азербайджанского села. Фактически такое положение вещей превращается в жесткую границу между сообществом недавних экономических мигрантов, самозанятых на петербуржских рынках, и этаблированными, великолепно интегрированными «азербайджанцами»-

${ }^{6}$ Список может быть продолжен, но это вопрос дальнейшего исследования.

7 Здесь мы используем понятия «азербайджанец», «таджик» и т.д. не как этнические категории, мы обозначаем место, откуда прибыл мигрант. 
интеллектуалами (в то время как теория культурных паттернов поведения - часто не столько социализационная, сколько примордиалистская - предполагает существование жесткой границы между «русским» и «азербайджанцем»). Таким образом, и в случае с культурными паттернами поведения не следует преувеличивать роль этничности: хотя культура, наряду с языком, несомненно, считается одним из основных составляющих феномена «этнической группы» [Smith 1986: 26], мы видим, что совершенно иное, отнюдь не «этническое» измерение культурных паттернов поведения оказывается значимым для мигрантов.

Рациональность (выгода). Этот критерий часто оказывается решающим при выборе партнеров, поставщиков, наемных рабочих. Например, на работу возьмут не co-ethnics, a дешевую рабочую силу, товар купят у того, кто продает дешевле, а продадут тому, кто купит дороже, и т.д. Цель миграции экономических мигрантов - максимально быстрое обогащение, относительная стабильность дохода. Поэтому именно экономическая деятельность становится основой формирующихся здесь социальных сетей. Отношения экономических мигрантов между собой строятся на основе принципов экономической рациональности. Поскольку экономические стратегии мигрантов индивидуальны, то по отношению друг к другу торговцы выступают в роли конкурентов, и поэтому каждый из них пытается перепродать товар другому «со-ethnics» с «накруткой».

С другой стороны, в ходе исследования мы наблюдали примеры сотрудничества мигрантов-азербайджанцев и местных предпринимателей. Такое сотрудничество в научной литературе по этническому бизнесу часто принято описывать как сотрудничество с другими этническими группами. Однако наш опыт наблюдений показывает, что это не сотрудничество представителей одной этнической группы с представителями другой этнической группы, а взаимовыгодное сотрудничество профессионалов. Этничность как таковая не играет роли при выборе того, с кем экономические мигранты сотрудничают, значимыми оказываются совершенно иные факторы. Примером такого сотрудничества, построенного исключительно на экономических принципах взаимовыгодности, являются отношения, связанные с продажей товара мелкооптовыми продавцами (жителями Ленинградской области) розничным продавцам (азербайджанцам). Эта ситуация может быть представлена: а) как взаимодействие русских с азербайджанцами; б) как взаимодействие мигрантов и местных; в) как взаимодействие мелкооптовых и розничных продавцов. Нам представляется, что именно последняя интерпретация наиболее адекватно описывает то, что в действительности происходит на рынках 8 .

Доверие/контроль. Исследователи социальных сетей придают особенно большое значение доверию, называя его «валютой», поскольку «доверие порождает взаимодействие» [РонаTас 1999: 402]. Однако, по нашим наблюдениям, границы доверия зачастую совпадают с границами контроля: доверяют тем, кого можно проконтролировать. Мигранты предпочитают давать деньги в долг тем, кто «достижим», например, работает на том же

8 Хочется отметить, что эпизоды подобного сотрудничества диссонируют с активно распространяемыми в СМИ мифами об экономическом ущербе, который якобы наносят стратегии экономических мигрантов-«кавказцев» «нашим» производителям, покупателям и т.п. На мелкооптовых поставщиков зелени никто не «давит», ни к чему не «принуждает», ничего не скупает «насильно», «под угрозами» (терминология из СМИ). Все отношения строятся на основе добровольного и взаимовыгодного сотрудничества. 
рынке. Этничность здесь не важна: таджик может одалживать деньги азербайджанцу, азербайджанец или молдаванка - таджику и т.д. Важно, чтобы на должника в случае нарушения обязательств можно было оказать давление.

Другой пример сочетания доверия/контроля возможно наблюдать в механизмах передачи мигрантами заработанных денег семьям на родину. Переправка денег осуществляется, в силу многих причин, не официальным способом почтовых или банковских переводов, а через социальные сети. Для передачи денег используются оказии с теми знакомыми, которые едут домой. Однако и в этом случае мигранты предпочитают передавать деньги с теми, кто достижим, кого можно проконтролировать на случай попытки присвоить чужие деньги. Контроль означает возможность применения санкций в отношении нарушителя договоренности. Например, нарушитель рискует своей репутацией, «дурная слава» о нем лишит его поддержки сети, т.е. фактически ограничит доступ к сетевым ресурсам.

Физическое пространство. Мигранты взаимодействуют с теми, с кем пересекаются и/или соседствуют в пространстве: с соседями по рынку, с хозяевами квартиры, с обслуживающим персоналом рынка, с теми, кто приходит на рынок, т.е. на «их пространство». Совместное [shared] пространство, в котором сосуществуют различные группы мигрантов и представителей местного населения, представляет собой определенную рамку, в которой разворачивается межличностное взаимодействие по поводу чего-либо. Через элементарное соприсутствие в пространстве находят наемных продавцов, партнеров по бизнесу, поставщиков товара, кредиторов и т.д. Наши информанты неоднократно находили поставщиков, покупателей и напарников не по принципу «среди своих соотечественников», но среди людей, с которыми пересекались в пространстве. Разумеется, здесь не имеет смысла отрывать физическое пространство от пространства социального: физическое пространство есть метафора пространства социального, оно объективирует социальные различия [Бурдье 1993: 36-37]. Если исходить из этой установки, то анализ физического пространства позволяет делать выводы о характере социальных феноменов, объективированных в этом пространстве. Однако следует внимательно присмотреться к тому, каковы же особенности этих социальных феноменов: какое измерение социального пространства наиболее значимо. Нам представляется, что в случае с экономическими мигрантами профессиональноэкономическое измерение не уступает этническому измерению, а иногда оказывается более значимым.

Давление извне. Давление извне формирует определенные рамки, в которых вынуждены жить мигранты. Для более полного анализа организации жизни мигрантов-«кавказцев» к измерению социального и физического пространств следует присовокупить измерение правового пространства. Предвзятое отношение к мигрантам, особенно к мигрантам из «южных» регионов, а также бесполезность и сложность бюрократических процедур по легализации мигрантами своего статуса ведут к тому, что подавляющая часть мигрантов группируются в нелегальном правовом пространстве. Дискриминация при приеме на работу (в сочетании с ограниченностью социального и финансового капитала) заставляет их группироваться в определенных сферах самозанятости, таких, как мелкая розничная и оптово-розничная торговля. Занятость в определенной сфере бизнеса ведет к физической концентрации в пределах городских рынков и вокруг них. Существование во всех пространствах взаимосвязано: каждое из них оказывает влияние на другие и само испытывает их влияние. 
Давление извне тесно связано с процессом, который может быть назван «навязыванием этничности» (термин, предложенный Д. Драгунским, 1993). Разумеется, нельзя говорить об отсутствии у мигрантов поведения, так или иначе определяемого их этнической принадлежностью. Однако, согласно нашим наблюдениям, случаи акцентуации этничности, как правило, инициированы извне. Например, ксенофобия со стороны местного населения определяет «чужих» в терминах этничности, выстраивает жесткую внешнюю границу. Таким образом все мигранты из Азербайджана, Таджикистана и других республик Кавказского и Закавказского регионов воспринимаются местным населением как «азербайджанцы» или «кавказцы». В том числе и те, для кого эта идентичность незначима 9 .

Безусловно, каждый из перечисленных компонентов, структурирующих существование наших информантов в ситуации миграции, сам по себе недостаточен для исчерпывающего объяснения жизни мигрантов - они поддерживают друг друга и должны пониматься во взаимосвязи.

\section{Заключение}

Нетрудно заметить, что «этничность» не попала в наш список факторов, ключевых для организации социальных сетей мигрантов. Элемент этничности, несомненно, не может совершенно не приниматься во внимание. Однако для наших информантов этничность не является достаточно важным ориентиром в их экономическом поведении. Это становится очевидно, если на минутку отвлечься от априори принятого в научном сообществе убеждения о существовании «этнических экономик» и важности этничности для стратегий мигрантов и обратиться, в первую очередь, к анализу реальной деятельности мигрантов. В результате нашего исследования мы пришли к выводам, которые могут быть суммированы следующим образом: 1) социальные сети мигрантов с Кавказа в Петербурге, в частности те, что носят экономический характер, организованы не по критерию этничности, т.е. они не созданы сознательно социальными агентами, субъективно ориентирующимися в своих действиях на этническую принадлежность тех, с кем они взаимодействуют [co-ethnics]; 2) гораздо большее значение в этих отношениях (по сравнению с этнической идентичностью) имеет позиция экономического мигранта, которая и вынуждает мигрантов строить свои социальные сети, ориентируясь на легкость и удобство, выгодность, доверие/контроль и другие принципы, описанные в статье.

\footnotetext{
${ }^{9}$ Другим примером «навязывания» этничности является работа исследователей и других экспертов в области этничности. Эти эксперты исходят из тех же «этнических» установок, когда стремятся изучать «этнический бизнес» и «этнические сообщества». В ответ информанты пытаются соответствовать ожиданиям исследователя. Например, мы, придя в поле, представлялись как исследователи азербайджанцев. Наши информанты искренне хотели помочь нам и считали необходимым объяснить, что такое настоящий азербайджанец. При этом воспроизводили общеизвестные культурные стереотипы. На самом деле это все имело весьма отдаленное отношение к тому, как организована жизнь мигрантов.
} 


\section{Литература}

Бурдье П. Физическое и социальное пространства: проникновение и присвоение // Бурдье П. Социология политики. M.: Socio Logos, 1993.

Вебер М. Основные социологические понятия. В: Избранные произведения. М.: Прогресс, 1990.

Воронков В., Освальд И. Введение. Постсоветские этничности // Конструирование этничности / Под ред. В.Воронкова и И. Освальд. СПб.: Дмитрий Буланин, 1998. C. 6-36.

Дятлов В. Диаспора и «торговый народ» // Сибирский еврейский сборник. № 2. Иркутск: «Арком», 1996.

Ильин В. Отечественный расизм // Альманах социальных исследований «Рубеж», 1994. №5. C. 189-204.

Радаев В. Этническое предпринимательство: мировой опыт и Россия // Политические исследования, 1993. №5. С. 79-87.

Рона-Тас A. Устойчивость социальных сетей в посткоммунистической трансформации Восточной Европы // Неформальная экономика. Россия и мир / Под. ред. Т.Шанина. М.: Логос, 1999. С. 396-411.

Снисаренко А. Этническое предпринимательство в большом городе современной России (на примере исследования азербайджанской общины в Петербурге) // Неформальная экономика. Россия и мир / Под ред. Т.Шанина. М.: Логос, 1999. C.138-155.

Light, I. Immigrant and Ethnic Enterprise in North America, Ethnic and Racial Studies (April 1984). Vol. 7, No. 2.

Light, I. Immigrant Entrepreneurs in America: Koreans in Los Angeles, in: Glazer, Nathan (ed.). Glamor at the Gates. San Francisco: ICS Press, 1985.

Light, I. Ethnicity and Business Enterprise, in: Stolarik, Mark, and Murray Friedman (eds.). Making It in America. L., Toronto: Associated University Presses, 1986.

Light, I., Sabagh, G., Bozorgmehr, M., and C. Der-Martirosia. Internal Ethnicity in the Ethnic Economy, Ethnic and Racial Studies (October 1993). Vol. 16, No. 4.

Light, I., and S. Karageorgis. The Ethnic Economy, in: Smelser, N., and R. Swedberg (eds.). The Handbook of Economic Sociology. Princeton: Princeton University Press, 1994.

Smith, A. The Ethnic Origins of Nations. L.: Basil Blackwell, 1986.

Waldinger, R., Ward, R., and H. Aldrich. Ethnic Business and Occupational Mobility in Advanced Societies, Sociology (November 1985). Vol. 19, No.4. P. 586-597.

Waldinger, R. Immigrant enterprise. A critique and reformulation, Theory and Society (1986). No.15

Ward, R. Ethnic Entrepreneurs in Britain and Europe, in: Coffee, R., and R.Scase (eds.). Entrepreneurship in Europe: The Social Process. L., N.Y.: Croom Helm, 1987.

Weber, M. What is an Ethnic Group, in: Guibernau, M., and J.Rex (eds.). The Ethnicity. Reader. Oxford: Polity Press, 1999. P. 15-26. 


\section{Дебютные работы}

$\boldsymbol{V} \boldsymbol{R}$ Размещаемый текст - часть дипломной работы выпускницы Государственного университета - Высшей школы экономики E. Скурятиной. Он посвящен подходам к определению стратегий финансового поведения и способам операционализации этих стратегий.

\section{СБЕРЕГАТЕЛЬНЫЕ СТРАТЕГИИ НАСЕЛЕНИЯ: ОСНОВНЫЕ ПОНЯТИЯ И ОПЕРАЦИОНАЛИЗАЦИЯ}

\section{Скурятина Елена}

Маркетинговое агентство «Russia Direct»

Email: lenask_home@mtu-net.ru

\section{Аннотация}

В данном эссе будут рассмотрены основные подходы к объяснению сберегательного поведения, центральная часть эссе посвящена стратегическому подходу. Вначале мы попытаемся теоретически определить понятие «сберегательная стратегия», а затем операционализировать это понятие на эмпирическом уровне. Особое внимание будет уделено проблемам и ограничениям, с которыми мы сталкиваемся при использовании данного подхода.

\section{Понятие «стратегии» в социальных науках}

Прежде чем говорить о сберегательных стратегиях, начнем с определения общего понятия стратегии. Следует отметить, что термин «стратегия» в социальных науках породил множество дискуссий: исследователи спорили о том, как определить стратегию, можно ли применять это понятие к социальным наукам, а одним из основных вопросов был вопрос о том, как разделить поведение на стратегическое и нестратегическое.

Так, Г.Кроу [Crowe] ${ }^{10}$ в 1989 г. достаточно подробно рассмотрел теоретические основания использования понятия «стратегия». Под «стратегией» он предполагал понимать «существование сознательных и рациональных решений в долгосрочной перспективе».

Другой исследователь, Д.Морган [Morgan $]^{11}$, указывал на то, что стратегии неразрывно связаны с решениями относительно использования и распределения ресурсов. Подчеркивая военное происхождение термина «стратегия», М.Шо [Shaw 1990] ${ }^{12}$ уделял особое внимание понятиям власти и доминирования в контексте стратегического поведения ${ }^{13}$.

10 Anderson, M., Bechhofer, F., and J.Gershuny. The social and political economy of the household. Oxford: Oxford University Press, 1994. P. 19.

${ }^{11}$ Anderson, M., Bechhofer, F., and J.Gershuny. Op. cit. P. 19-67.

12 Shaw, M., Strategy and Social Process: Military Context and Social Analysis, Sociology (1990). Vol. 24, No. 3, p. 465-73.

${ }^{13}$ Anderson, M., Bechhofer, F., and J.Gershuny. Op. cit. P. 19-67. 
Несмотря на различие подходов, большинство исследователей считают, что термин «стратегия» уместно использовать в случае, когда требуется понять, каким образом индивидь и группь сознательно структурируют свои действия в долгосрочной перспективе. Стратегии, таким образом, - это конструкты высокого порядка, которые формируют действия и их задают основные направления. Стратегия может пониматься как определение, выбор некоей цели, а тактика - как набор определенных действий для достижения этой цели. При этом следует отметить, что в контексте отсутствие действия тоже может являться стратегией.

Большинство социологов интерпретируют стратегию не как виды поведения или практики, но как системы рационально обоснованных решений, которые приводят к желаемой среднесрочной или долгосрочной цели. С этой точки зрения стратегии не могут быть статичными, они будут меняться под воздействием внешних обстоятельств. Основная предпосылка такого подхода состоит в том, что акторы знают все виды «стратегий», из которых им надо сделать выбор ${ }^{14}$.

Таким образом, стратегический подход достаточно интересен, так как является неким компромиссом между структурой и действием. Сторонники структурного подхода утверждают, что человеческое поведение ограничено социальной структурой - нормой, правилами, социальными институтами. Существует и прямо противоположный взгляд, когда считается, что человек свободен в выборе, и основной движущей силой, побуждающей его к действию, является максимизация полезности, т.е. экономическая рациональность. Таким образом, получаются своего рода полюса - человек социальный и человек экономический. Стратегический же подход позволяет говорить о некоем переходном типе, так как, с одной стороны, человек свободен в выборе собственной стратегии поведения, но, с другой стороны, выбор этой стратегии ограничен набором, или репертуаром, уже существующих социальных стратегий.

\section{Сберегательное поведение и сберегательные стратегии: разграничение понятий}

Мы предлагаем трактовать понятия стратегии и поведения, т.е. сберегательную стратегию, не как определенную модель сберегательного поведения, но как сознательное структурирование сберегательных действий в долгосрочной перспективе для достижения поставленной цели. Важно подчеркнуть, что стратегия должна быть реализуемой. Однако при таком подходе возникает ряд вопросов, которые нельзя не затронуть ${ }^{15}$.

Прежде всего, если стратегия не равна поведению, то как отличить стратегическое поведение от нестратегического? Например, если стратегия всегда долгосрочна, то она должна состоять из определенных стадий реализации; однако как определить при переходе от одной стадии к другой, является ли это внутренним переходом или уже начинается новая стратегия? И главный вопрос - насколько длителен этот долгосрочный период? Например, можно ли считать долгосрочным периодом один год? Если исходить из традиционных экономических понятий долгосрочного/среднесрочного/ краткосрочного

\footnotetext{
${ }^{14}$ Там же.

${ }^{15}$ Kouzina, O.E. Individual and household financial strategies in economic theory, economic psychology and economic sociology // Manuscript, 2001.
} 
периодов, то нет. Но тогда получается, что сберегательное поведение в течение года не может считаться стратегией - хотя, например, вполне возможен вариант, когда человек в течение года копит на автомобиль и покупает его, т.е. полностью реализует свою стратегию. В конце концов, время, которое требуется человеку для реализации его цели, индивидуально и зависит в первую очередь от объема его дохода, от того, насколько он ограничивает себя в потреблении, т.е. какую долю дохода сберегает, а также от того, насколько серьезных материальных вложений требует реализация его цели. Например, если человек с достаточно высоким ежемесячным доходом поставил себе целью копить на автомобиль и купил его за три месяца, можно ли это считать стратегией? Если мы ответим отрицательно в связи с тем, что период краткосрочный, то чем тогда отличается поведение индивида с гораздо меньшим уровнем ежемесячного дохода, который поставил целью накопить средства на покупку автомобиля и купил его по истечении трех лет? Это, согласно нашему определению, стратегия в чистом виде, хотя принципиальной разницы в поведении между этими двумя индивидами нет.

Еще один слабый пункт - то, что стратегия предполагает наличие определенной цели. Как быть в том случае, если цель меняется? Например, индивид осуществлял сбережения с целью купить автомобиль, и когда он скопил половину нужной суммы, автомобиль ему неожиданно подарили, а накопленные средства он потратил на ремонт квартиры. Можно ли сказать про такого индивида, что у него не было стратегии или что он не смог ее реализовать? Ни то, ни другое не будет верным: у индивида была цель и была стратегия, но на определенном этапе цель сменилась. Означает ли это смену стратегии? Однозначно ответить на этот вопрос нельзя.

Далее, очень трудно понять, насколько сознательной является та или иная стратегия. Например, индивид предпочитает хранить средства в наличной форме - является ли это сознательной стратегией? Да, если он рассмотрел все возможные варианты, взвесил все «за» и «против» и выбрал данную форму. А если он поступает так только потому, что так было принято в семье его родителей?

И наконец, последняя проблема - возможность реализации. Можно ли считать стратегией то, что заведомо нельзя реализовать?

И как быть со стратегией не делать чего-то - например, не брать в долг. В принципе, это тоже можно считать своего рода стратегией.

Принимая во внимание данные ограничения, такое определение стратегии вряд ли будет хорошо работать на эмпирических данных.

Следует отметить, что возможен еще один подход к определению стратегии - с учетом четырех типов веберовского поведения: целеориентированное и ценностноориентированное поведение можно считать стратегическим поведением, а традиционное и аффективное поведение можно отнести к нестратегическому поведению.

\section{Основные подходы к объяснению сберегательного поведения}

Рассмотрим основные подходы к объяснению сберегательного поведения. Это неоклассические экономические теории, психологические и социологические теории, а также бихевиористский и институциональный подходы. 
Сберегательное поведение с точки зрения экономистов

Одним из первых экономистов, занимавшихся вопросами сбережений, был Дж. М. Кейнс. В его теории абсолютного дохода [absolute income hypothesis] расходы и сбережения потребителей рассматривались как функция от дохода, при этом доля сбережений повышалась при увеличении уровня реального дохода. Данная гипотеза, однако, не объясняла разницу в объеме сбережений у разных социальных групп.

Гипотеза относительного дохода [relative income hypothesis], предложенная Дж.Дьюзенбери, была первым шагом на пути отказа от единственной объяснительной модели и признания множественности сберегательных стратегий, реализуемых домохозяйствами. По мнению Дьюзенбери, сберегательное поведение социально и культурно обусловлено, и индивид стремится в своем поведении реализовать модель, принятую в его социальной группе ${ }^{16}$.

Неоклассические экономические теории сберегательного поведения характеризуются несколькими общими предпосылками. Индивиды рассматриваются как рациональные существа, которые максимизируют удовольствие и минимизируют негативные моменты, а полезность является функцией от потребления. Неоклассики предполагают, что индивиды должны делать выбор между настоящим и будущим потреблением. Этот выбор результат стабильных, индивидуальных предпочтений и существования определенного набора возможностей.

Две наиболее известные неоклассические теории сбережения - теория жизненного цикла Ф. Модильяни ${ }^{17}$ и теория перманентного дохода М. Фридмана ${ }^{18}$. В обеих теориях предполагается, что индивиды заинтересованы в потреблении в долгосрочном периоде, и потребление и сбережения объясняются в терминах ожидаемого будущего дохода. Сбережения дают возможность сгладить уровень потребления при колебаниях доходов. Согласно этим теориям, когда текущий доход падает ниже среднего ожидаемого за жизненный цикл, сбережения уменьшаются, и индивиды даже могут брать в долг, чтобы потребление осталось на прежнем уровне. Если же текущий доход превышает средний за жизненный цикл, индивиды сберегают.

Что касается теорий жизненного цикла, то, как следует из названия, сберегательное поведение зависит от того, на каком этапе своей жизни находится индивид. Поскольку у большинства людей доход резко сокращается после выхода на пенсию, мотив сбережений «на старость» становится основным мотивом.

И теории жизненного цикла, и теории постоянного дохода предполагают, что главной детерминантой потребления в долгосрочном периоде является доход.

\footnotetext{
${ }^{16}$ Kouzina, O.E. Individual and household financial strategies in economic theory, economic psychology and economic sociology // Manuscript, 2001.

${ }^{17}$ Modigliani, F. Life Cycle, Individual Thrift and Wealth of Nations, American Economic Review (1986). Vol. 76, No. 3.

${ }^{18}$ Friedman, M. A Theory of the Consumption Function. Princeton: Princeton University Press, 1957.
} 
Сберегательное поведение в психологических теориях

Психологические теории рассматривают дополнительные детерминанты сберегательного поведения. Они основываются на предположении, что потребительские вкусы и предпочтения не зафиксированы, а подвержены воздействию экономических и социальных условий. Психологические теории в особенности часто опираются на схему «стимул - реакция» (Г. Катона).

Катона $^{19}$ предложил рассматривать сбережение как функцию от двух переменных: возможности сберегать [ability to save] и желания сберегать [willingness to save]. Возможность сберегать связана с ограниченностью экономических ресурсов: некоторые индивиды не могут делать сбережения из-за небольшого размера дохода.

В то же время индивиды, которые могут делать сбережения, должны иметь соответствующее желание, ибо это требует определенной силы воли.

В бихевиористских теориях (хотя они и опираются частично на экономические предпосылки), не предполагается ни существования фиксированных предпочтений в отношении сбережений и потребления, ни того, что индивидуальное экономическое поведение определяется индивидуальными предпочтениями и материальными ограничениями. Одна из основных теорий здесь - бихевиористская теория жизненного цикла $^{20}$, основывающаяся на экономической теории «самоконтроля» [self-control] ${ }^{21}$. Согласно этой теории, индивид может рассматриваться одновременно как стратег и как исполнитель. Стратег строит свое поведение исходя из полезности в рамках жизни в целом, тогда как исполнитель озабочен лишь сиюминутной выгодой и максимизирует полезность лишь в краткосрочном периоде.

Часто индивиды добровольно принимают правила, ограничивающие их потребление (например, начинают копить на подарки к празднику или принимают за правило «не брать долгов»). В итоге сберегательное поведение индивидов и домохозяйств становится результатом сложного процесса выбора между улучшением благосостояния посредством потребления и необходимостью ограничивать потребление за счет самоконтроля.

В рамках институционального подхода основополагающими являются предпосылки о том, что сберегательное поведение домохозяйств и индивидов определяется институтами, через которые реализуются сберегательные стратегии. Предполагается, что институты могут отклонять поведение индивидов от той линии поведения, которая в неоклассических теориях считается оптимальной. Так, в обществе с развитой системой пенсионных фондов индивиды с меньшей вероятностью будут осуществлять сбережения «на старость», чем в обществе, где система пенсионного обеспечения плохо развита или отсутствует.

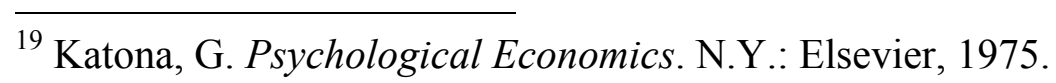

${ }^{20}$ Shefrin H., and R. Thaler. The Behavioral Life-Cycle Hypothesis, Economics Inquiry (1988). Vol. 26. P. 609-643.

${ }^{21}$ Thaler, R. and H. Shefrin. An economic theory of self-control, Journal of Political Economy (1981). Vol. 89, No 2. P. 392-401.
} 


\section{Сберегательное поведение с точки зрения сочииологов}

Следует отметить, что социологической литературы по данной тематике достаточно мало. Среди важных работ можно упомянуть следующие. Ж. Пал является автором известного подхода, в центре внимания которого - проблема контроля и распределения ресурсов в домашнем хозяйстве. Отличие социологического подхода от всех прочих, прежде всего, в фиксировании социального значения денег. Так, В. Зелизер утверждает, что деньги персонализированы и имеют для индивида различное значение в зависимости от своего источника и предназначения. Это сходно с идеями Г. Шефрина и Р. Талера, которые предполагали, что склонность к сбережениям различается в зависимости от источника получения доходов.

Социологи предположили также, что процесс принятия решений относительно денежных средств в домохозяйстве очень сложен и зависит от того, как распределены роли в семье и кто контролирует бюджет.

Кроме того, социологами рассматривались сбережения с точки зрения институциональных ограничений, доступности финансовых институтов для индивидов ${ }^{22}$.

Помимо традиционных экономических и психологических переменных исследователями стали учитываться и такие переменные, как уровень временного предпочтения [rate of time preference $]^{23}$, социализация и обучение ${ }^{24}$, нормы референтных групп ${ }^{25}$, условия проживания ${ }^{26}$.

${ }^{22}$ Kuzina, O.E. Individual and household financial strategies in economic theory, economic psychology and economic sociology // Manuscript, 2001.

${ }^{23}$ Уровень временного предпочтения - это мера желания индивида отложить потребление на определенный срок, например, на год. Рациональный индивид в капиталистическом обществе должен иметь уровень временных предпочтений, равный ставке процента на рынке.

${ }^{24}$ Например, Коэн полагает, что основы будущего финансового поведения закладываются в семье. Умение распоряжаться ресурсами и вести хозяйство закладываются в семье, когда дети наблюдают за поведением взрослых. Индивидуальные потребительские и сберегательные привычки формируются в семье.

25 Дьюзенбери утверждает, что в своем потреблении и сберегательном поведении индивид ориентируется на группы, к которым он хочет принадлежать. Поэтому и потребительское, и сберегательное поведение может определяться культурными и социальными нормами.

26 Люди, живущие в бедных кварталах и неблагополучных районах, будут меньше сберегать, особенно в форме жилья и товаров длительного пользования, поскольку здесь подобные сбережения с большей вероятностью будут украдены, сожжены и т.д. Кроме того, жильцы бедных кварталов имеют очень ограниченный доступ к финансовым институтам. 


\section{Выбор сберегательной стратегии}

Рассмотрим основные этапы принятия решений индивидом при выборе сберегательной стратегии. Первый шаг - это принципиальный стратегический выбор сберегать/не сберегать, на который оказывает влияние множество переменных (уровень доходов, необходимые расходы, психологические склонности и т.п.). При этом данный шаг тесно связан с целями (мотивами) сбережений, так как индивид, задумываясь о том, стоит сберегать или нет, не может не думать о целях (даже если он не имеет конкретных целей, а хочет просто иметь сбережения, это можно трактовать как мотив «на всякий случай»). Тем не менее, приняв решение о том, что он будет сберегать, индивид (или домохозяйство) сталкивается с рядом препятствий [obstacles to saving], которые могут быть связаны с изменениями в текущем доходе, с появлением непредвиденных расходов, с макроэкономическими изменениями. Как индивид приспосабливается к изменениям, какие формы сбережений выбирает - это дальнейшие тактические шаги, которые, в конечном итоге, приводят к результату - наличию или отсутствию сбережений.

$\mathrm{C}$ точки зрения сберегательного поведения умение сберегать предполагает умение мыслить перспективно, что приводит к идее о том, что наличие или отсутствие стратегии может коррелировать с наличием или отсутствием сбережений. Таким образом, наличие/отсутствие стратегии может являться еще одной детерминантой сберегательного поведения.

\section{Основные детерминанты сберегательного поведения}

В простейшей модели сбережения определяются эномическими и демографическими переменными (такими, как доход, богатство, возраст, образование) и психологическими переменными (предпочтениями, сберегательными мотивами, ожиданиями).

Есть и более сложная модель сбережений. Сюда добавляются контекстуальные переменные - социологические и институциональные. Для объяснения сберегательного поведения используются такие социологические понятия, как референтные группы, социальное окружение; при этом на сбережения влияют институциональные переменные: финансовое образование, уровень прибыльности инвестиций. С учетом нашей гипотезы о влиянии сберегательной стратегии на наличие/отсутствие сбережений и о взаимосвязи между формами и мотивами модель сберегательного поведения может выглядеть следующим образом.

Схема 1. Модель сберегательного поведения

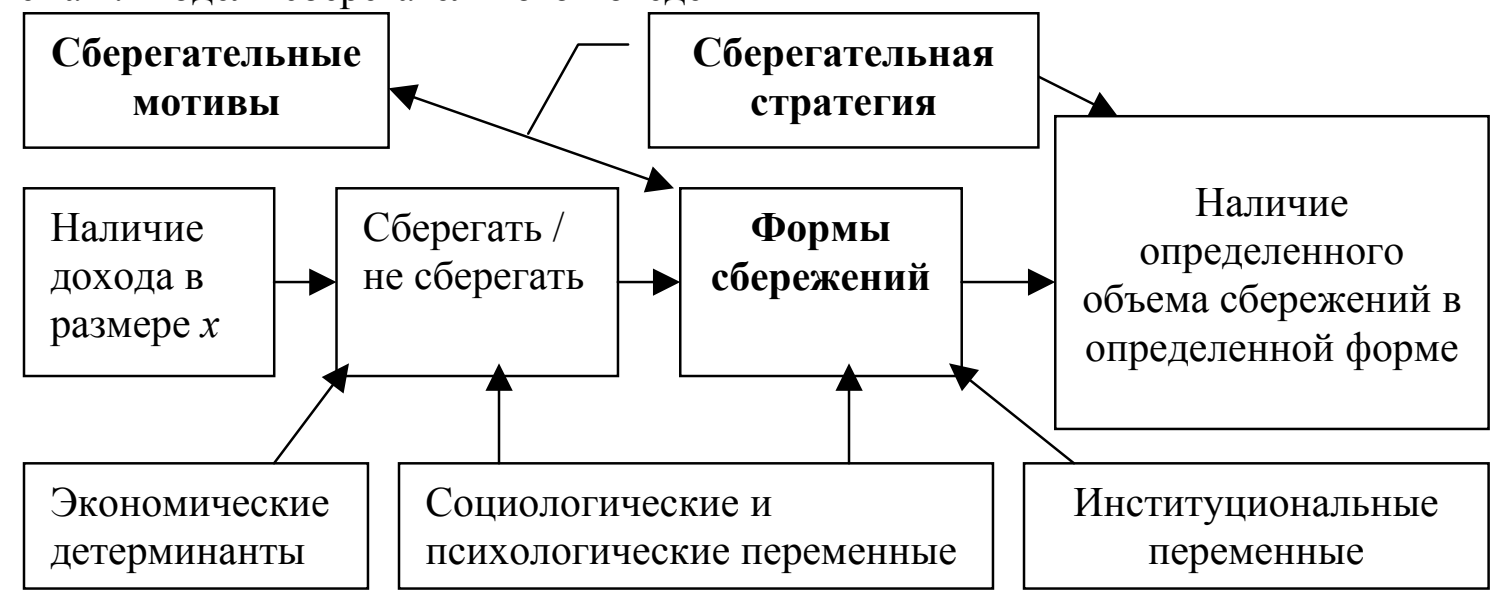




\section{Сберегательные стратегии: операционализация на эмпирическом уровне}

Рассмотрим, каким образом можно применить стратегический подход на эмпирическом уровне. С одной стороны, если мы исходим из предположения о том, что стратегическое поведение преимущественно долгосрочно, то для измерения сберегательных стратегий населения было бы логичным использовать панельные исследования. Ведь именно такой вид исследования может помочь в изучении процесса выбора и реализации той или иной стратегии. С другой стороны, имеет смысл изучать сберегательные стратегии на данных выборочных исследований, поскольку именно на этих данных возможно выявить некие типичные сберегательные стратегии, наиболее распространенные в обществе.

В качестве примера выделения сберегательных стратегий на основе эмпирических данных рассмотрим взаимосвязь между формами сбережений и сберегательными мотивами. Прежде чем говорить о сочетании форм и мотивов, проанализируем их основные характеристики: это позволит в дальнейшем определить точки их возможного соприкосновения и пересечения.

Основные характеристики мотивов включают сохранение имеющихся средств или получение максимально возможного приращения средств. Что касается форм, то их основные характеристики - это прибыльность и надежность. Есть также общая для этих двух переменных категория - срок, в течение которого стратегия реализуется.

Ниже приведены две таблицы, обобщающие основные характеристики форм и мотивов.

Таблица 1. Основные характеристики мотивов

\begin{tabular}{|c|c|c|c|}
\hline Мотивы & $\begin{array}{l}\text { Период } \\
\text { реализации }\end{array}$ & $\begin{array}{l}\text { Tребуемый } \\
\text { объем средств } \\
\end{array}$ & Оптимальная форма \\
\hline $\begin{array}{l}\text { На покупку дорогих } \\
\text { вещей }\end{array}$ & $\begin{array}{l}\text { Короткий / } \\
\text { средний }\end{array}$ & Средний & Наличная валюта, наличные рубли \\
\hline $\begin{array}{l}\text { На покупку квартиры, } \\
\text { собственного дома }\end{array}$ & Длительный & Большой & $\begin{array}{l}\text { Сбербанк, коммерческий банк, } \\
\text { государственные ценные бумаги, акции }\end{array}$ \\
\hline На образование & $\begin{array}{l}\text { Средний / } \\
\text { длительный }\end{array}$ & $\begin{array}{l}\text { Средний / } \\
\text { большой }\end{array}$ & Сбербанк, коммерческий банк \\
\hline На лечение & $\begin{array}{l}\text { Короткий / } \\
\text { средний }\end{array}$ & $\begin{array}{l}\text { Средний / } \\
\text { большой }\end{array}$ & Валюта, Сбербанк \\
\hline $\begin{array}{l}\text { На отдых, развлечения, } \\
\text { путешествия }\end{array}$ & $\begin{array}{l}\text { Короткий / } \\
\text { средний }\end{array}$ & $\begin{array}{l}\text { Средний / } \\
\text { большой }\end{array}$ & Валюта, Сбербанк \\
\hline $\begin{array}{l}\text { На собственное дело, } \\
\text { покупку акций }\end{array}$ & $\begin{array}{l}\text { Средний / } \\
\text { длительный }\end{array}$ & Большой & Акции, коммерческий банк \\
\hline $\begin{array}{l}\text { На покупку земли, дачи, } \\
\text { садового домика }\end{array}$ & Длительный & Большой & Сбербанк, коммерческий банк \\
\hline На покупку автомобиля & $\begin{array}{l}\text { Средний / } \\
\text { длительный }\end{array}$ & Большой & Сбербанк, коммерческий банк \\
\hline $\begin{array}{l}\text { На всякий случай, про } \\
\text { запас }\end{array}$ & Любой & Любой & Наличные рубли, валюта \\
\hline
\end{tabular}


Таблица 2. Основные характеристики форм

\begin{tabular}{|c|c|c|c|c|c|c|}
\hline Формы & 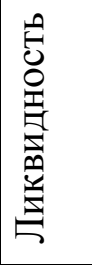 & 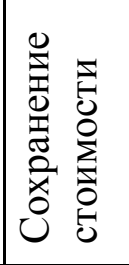 & 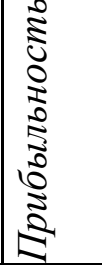 & 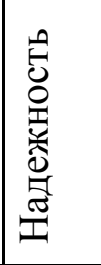 & 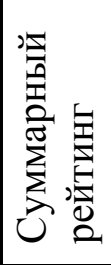 & Оптимальный период \\
\hline Сбербанк & 2 & 2 & 2 & 3 & 9 & $\begin{array}{l}\text { Средний / } \\
\text { длительный }\end{array}$ \\
\hline Коммерческие банки & 2 & 2 & 3 & 2 & 9 & $\begin{array}{l}\text { Средний / } \\
\text { длительный }\end{array}$ \\
\hline $\begin{array}{l}\text { Государственные } \\
\text { ценные бумаги }\end{array}$ & 1 & 2 & 2 & 2 & 7 & $\begin{array}{l}\text { Средний / } \\
\text { длительный }\end{array}$ \\
\hline Акции & 1 & 2 & 2 & 1 & 6 & $\begin{array}{l}\text { Средний / } \\
\text { длительный }\end{array}$ \\
\hline Наличные рубли & 3 & 1 & 1 & 1 & 6 & Короткий \\
\hline Наличная валюта & 2 & 3 & 2 & 1 & 8 & $\begin{array}{l}\text { Короткий / } \\
\text { средний }\end{array}$ \\
\hline $\begin{array}{l}\text { Драгоценные металлы, } \\
\text { антиквариат }\end{array}$ & 1 & 3 & 2 & 2 & 8 & Длительный \\
\hline
\end{tabular}

Таким образом, сочетание мотивов и форм имеет определенные общие аспекты, на основании которых можно говорить о неких устойчивых типах поведения сберегательных стратегиях. Обосновывая свой выбор в отношении именно этих двух переменных, хотелось бы отметить, что при реализации сберегательной стратегии человек не может обойтись без ответа на два ключевых вопроса: стоит ли сберегать (есть ли цель, мотив) и, если да, то как сберегать (в какой форме). Следует отметить, что от выбора формы зачастую зависит в принципе, реализует ли человек поставленную цель или нет. Например, если человек недооценил степень риска и вложил деньги в банк, который впоследствии обанкротился, он явно в проигрыше. Это означает, что выбранная им стратегия оказалась на данный момент не удачной и не привела к реализации его цели.

Кроме того, на уровне здравого смыла было бы логично предположить наличие неких устойчивых взаимосвязей «мотивы - формы»: например, если мотив предполагает сохранность средств в течение длительного периода времени (как, допустим, распространенный мотив «на старость»), то кажется логичным, что и форма будет соответствующая - более надежная, но менее прибыльная (например, Сбербанк). А если мотив предполагает не только сохранение, но и приумножение средств, причем в течение достаточно короткого времени (например, молодая семья с достаточно высоким уровнем заработка решает купить квартиру), то для такого мотива гораздо логичнее более рискованная, но в то же время и более прибыльная форма (например, вложение денег в ценные бумаги).

Перейдем теперь к попытке анализа сочетаемости форм и мотивов и возможности выделения соответствующей стратегии на основе эмпирических данных. 
Один из методов - это анализ наличия взаимосвязей по каждой из форм и мотивов. Для этого можно использовать таблицы сопряженности (сочетание каждого мотива и каждой формы) и анализировать коэффициенты значимости (посмотреть на уровень значимости, при котором отвергается гипотеза об отсутствии связи между признаками). Полученные результаты затем можно свести в единую таблицу, которая даст наглядное представление о существующих взаимосвязях.

Второй метод - это использование факторного и кластерного анализов. Сначала проводится факторный анализ на формах и мотивах, полученные факторы сохраняются как новые переменные. Затем с помощью кластерного анализа проводится группировка респондентов и выделяются группы респондентов со сходными сберегательными стратегиями. Следует отметить, что такой анализ лучше проводить на данных, достаточно однородных по уровню дохода, так как доход является одной из главных детерминант и может достаточно сильно повлиять на результат при проведении кластерного анализа.

При использовании обеих методик основная задача состоит в том, чтобы выявить некие устойчивые сочетания форм и мотивов, которые можно было бы считать стратегиями.

\section{Заключение}

Стратегический подход к объяснению сберегательного поведения интересен, хотя сложности при его применении возникают на уровне как теории, так и методологии. Возникает множество вопросов, главным из которых, на наш взгляд, является вопрос о том, можно ли в принципе разделить поведение на стратегическое и нестратегическое, и если да, то каким образом можно измерить наличие / отсутствие стратегии и выделить различные виды стратегий. Однако, отделяя сберегательные стратегии (которые операционализируются как сочетание форм и мотивов) от сберегательного поведения (которое операционализируется как наличие / отсутствие сбережений), можно говорить о том, что сами стратегии при этом становятся еще одной детерминантой наличия / отсутствия сбережений. 


\section{Профессиональные обзоры}

$\boldsymbol{V R}$ Предлагается очередной страновой материал - «Экономическая социология в Португалии», переведенный из Европейского Ньюслеттера «Экономическая социология» (авторы - Ж. Пейшоту и Р. Маркеш). Несколько лет назад авторы организовали в Португалии одну из наиболее крупных конференций экономсоциологов в Европе. Выступали они и у нас в Москве на конференции «Экономическая социология на пороге третьего тысячелетия» (январь 2000 г.) [о конференции см.: Том 1, №1 (2000)].

\section{ЭКОНОМИЧЕСКАЯ СОЦИОЛОГИЯ В ПОРТУГАЛИИ Жуау Пейшоту и Рафаэль Маркеш}

Исследовательский центр экономической социологии и социологии организаций «Социус»,

Институт экономического и делового администрирования, Технический университет Лиссабона

Email: jpeixoto@iseg.utl.pt; rmarques@iseg.utl.pt

\section{Перевод М.С. Добряковой}

Научное редактирование - В.В. Радаев

В данной статье мы рассматриваем становление экономической социологии в Португалии. Сначала мы анализируем ее институциональный контекст, делаем обзор исследований, которые изначально определены как экономико-социологические или которые пытаются выстроить прямые связи между экономической теорий и социологией. Затем мы перечисляем другие исследования, тесно связанные с данной областью. Поскольку четко определить статус исследований непросто, список авторов, упоминаемых в данной работе, следует считать незавершенным.

\section{Институционализированная экономическая социология}

В Португалии социология институционализировалась лишь после 1974 г., когда началась политическая демократизация страны. Если говорить об образовательных дипломах или тематической структуре исследований, то некоторые направления португальской социологии весьма стабильны. Среди них можно назвать индустриальную социологию и

${ }^{1}$ Перевод статьи: Peixoto, J., and R. Marques. Economic Sociology in Portugal // Economic Sociology: European Electronic Newsletter. Vol. 3, No. 1 (October 2001). P. 24-30 / www.siswo.uva.nl/ES.

${ }^{2}$ Мы хотели бы поблагодарить Сару Фалкау Касака [Sara Falcão Casaca] и Жозе Мануэля Мендеша [José Manuel Mendes], а также других наших коллег по «Социусу» за их замечания по поводу данной статьи. Как и принято в таких случаях, все недостатки работы следует относить на счет авторов. 
социологию труда, исследования города и территориальные исследования, социологию образования и социологию семьи. Экономическая же социология, напротив, упоминается достаточно редко. Есть, однако, и некоторые исключения. С формальноинституциональной точки зрения, Институт экономического и делового администрирования [ISEG] при Техническом университете Лиссабона может быть назван оплотом экономической социологии в Португалии. В нем еще в 1991-1992 гг. были открыты программы докторской и магистерской подготовки по специальностям «экономическая социология» и «социология организаций»; в 1991 г. был создан Исследовательский центр экономической социологии и социологии организаций «Социус» [SOCIUS] $]^{3}$. Среди других институтов, в которых развивается эта новая область, - Школа экономики Университета Коимбры, где программа Ph.D. по социологии включает специальность «экономическая социология», и Институт социальных наук [ICS] при Университете Лиссабона, где экономическая социология и социология развития находятся в числе сильнейших исследовательских направлений. За пределами этих институтов наименование «экономическая социология» используется редко. Более того, следует подчеркнуть, что институционализация данной области в некоторых ведущих школах экономики и менеджмента не означает возникновения плодотворного диалога между социологией и экономической теорией или проведения ими совместных исследований.

Хотя в настоящее время развитие экономической социологии - задача, к которой обращаются лишь немногие исследователи, в 1960-е гг. планы на этот счет казались более амбициозными. Журнал «Социальный анализ» [Análise Social], ориентированный на проблемы современной социологии, в одном из первых номеров поставил своей задачей связать экономическую теорию и социологию. В 1964 г. в своем вступительном слове, посвященном 50-му юбилею Школы экономики (нынешней ISEG), редакция объявила о своем намерении «...внести серьезный вклад в расширение спектра исследований в области экономического развития в Португалии; открыть ряд дискуссионных рубрик; при анализе фактов и постановке проблем предоставить место обсуждению вопросов, которым не уделялось внимание прежде» [VVAA 1964: 404]. С этой целью и делался призыв к «междисциплинарному диалогу» ${ }^{4}$. Некоторые статьи, опубликованные в «Социальном анализе» в 1960-е гг., следуют именно этому руслу. Два специальных выпуска были посвящены теме развития: выпуск 1964 г. - социальным аспектам развития, выпуск 1969 г. - его социальным и институциональным особенностям. Наиболее важный вклад внесли Адериту Седаш Нунеш [Adérito Sedas Nunes] (его считают отцом-основателем современной португальской социологии) и Алфреду де Соза [Alfredo de Sousa], оба они по

${ }^{3}$ Курсы по экономической социологии и социологии финансовых рынков читаются в Институте также и для студентов, изучающих экономическую теорию, менеджмент и финансы.

${ }^{4}$ Надо, однако, пояснить специфический контекст, в котором прозвучал этот призыв. Его целью было не столько примирить экономическую теорию и социологию (поскольку последняя тогда вообще едва ли существовала), сколько не допустить институциональных ограничений на пути развития социологии и придать экономическим исследованиям (равно как и политическим дебатам) также и социальное измерение. Более широкая социальная перспектива расширила возможности этих авторов к критике, а также укрепила позиции разделяемой многими социальной католической доктрины. 
образованию экономисты. В их работах рассматриваются социальные, культурные и политические аспекты экономического развития, вопросы социальной стратификации и новые классы специалистов [new knowledge classes]; Седаш Нунеш писал также о методах современной социологии, а Соза анализировал различные концепции времени как культурный фактор экономического развития. И также в 1960-е гг. журнал опубликовал статью Жана Куизеньера, посвященную «социологии хозяйства» и развивавшую тематику других работ того периода [Cuisennier 1965]. В ней указывалось на решающее значение социальных переменных и поведения агентов для выработки планов развития [planning design].

После 1974 г. специализация в социальных науках усилилась, и попытки «диалога» стали более вялыми. Краткий обзор основных португальских социологических журналов позволяет обнаружить лишь незначительное количество работ, напрямую связывающих экономическую теорию и социологию или явно ссылающихся на экономическую социологию. Среди важных исключений - статья Илоны Ковач из Института экономического и делового администрирования [ISEG], призывающая к более плодотворному диалогу между экономической теорией и социологией, который явился бы ответом на сложность и неопределенность современной эпохи и помог бы сформировать столь необходимый интегративный стиль мышления [Kovács 1985]. Некоторые статьи, опубликованные в «Журнале социальных наук» [Cadernos de Ciências Sociais] (Университет Порту) такими авторами, как, например, Жозе Мануэль Морейра [José Manuel Moreira 1986], призывали пересмотреть основные исходные положения неоклассической экономической теории и в частности - понятие рациональности, позитивистскую методологию, отрыв от социальных норм и проблем этики. Жуау Фрейре [João Freire] предлагал обратиться к социологии хозяйственной жизни, уделяя особое внимание исследованию производства, потребления, предпринимательства и финансовых систем (он ставил своей задачей увязать эти темы с произошедшей, наконец, «демократизацией» экономики) [Freire 1991]. Жуау Аррискадо Нунеш (Университет Коимбры) посвятил несколько работ анализу идей К.Поланьи о социальном и экономическом способах регулирования хозяйства и социологии хозяйственной жизни [например, Nunes 1994, 1998]. Наконец, такие авторы, как Аделину Торреш [Adelino Torres], Жозе Луиш Кардозо [José Luís Cardoso], Франсиску Луиса [Francisco Louçã], Антониу Алмодовар [António Almodôvar], Фернанду Катрога [Fernando Catroga] и Мария де Фатима Брандау [Maria de Fátima Brandão] исследовали проблему отношений между экономическим и социологическим типами мышления.

Что касается последних исследований - именующих себя экономико-социологическими и выполненными с теоретических позиций экономической социологии - то большая их часть вполне закономерно выполняется силами Института экономического и делового администрирования [ISEG] и, в особенности, силами «Социуса» [SOCIUS]. В чем-то их работа следует традиционным направлениям исследования - например, социологии труда и индустриальной социологии, другие исследования более тесно связаны с тем, что сейчас принято называть новой экономической социологией. К последним мы относим, в частности, работы таких авторов, как: Жозе Мария Карвальу Ферейра [José Maria Carvalho Ferreira] (посреднические институты, или организации третьего сектора); Жуау Пейшото [João Peixoto] (международная мобильность высококвалифицированных работников); Анабела Карвальу [Anabela Carvalho] (этническое предпринимательство на примере индийских и исламских этнических групп); Мария Жуау Сантош [Maria João Santos] 
(трансформация производства в контексте локального развития); Жуау Карлош Граса [João Carlos Graça] (исследование работ Жозе Фредерику Ларанжу [José Frederico Laranjo] - португальского обществоведа, писавшего на рубеже XIX-XX вв.); Рафаэль Маркеш [Rafael Marques] (общая теория реципрокности); Рита Рапозу [Rita Raposo] (закрытые поселенческие сообщества [gated communities] как процесс социального и экономического потребления); Марта Варанда [Marta Varanda] (проблемы коллективного действия малых предпринимателей в секторе традиционного бизнеса; это первая попытка применения сетевого анализа в Португалии) $)^{5}$. Некоторые из этих авторов в настоящее время готовят к изданию первую хрестоматию по новой экономической социологии на португальском языке [Marques and Peixoto, в печати].

Именно «Социус» первым организовал научные мероприятия, целиком посвященные вопросам экономической социологии. Первый семинар состоялся в 1995 г. Его результаты воплотились в книге «Между экономической теорией и социологией» [Ferreira et al. 1996]. $\mathrm{Ee}$ основные разделы посвящены историческому анализу экономической и социологической мысли, теоретическим дебатам в современной экономической социологии, теоретическому и эмпирическому анализу смежных областей (исследованиям ценностей и развития, бедности и исключения, миграции и предпринимательства). Особый инновационный подход представлен в главах Жуау Аррискаду Нунеша [Јоа̃о Arriscado Nunes] и Карлоша Гонсалеса [Carlos Gonçalves] (Университет Порту), посвященных социологии экономической мысли [sociology of economics]. Используя также свои прежние работы, Нунеш анализирует влияние культуры на экономический дискурс и утверждает, что современное состояние последнего свидетельствует о том, сколь важна роль господствующей риторики (он использует здесь теоретические концепции Д. МакКлоски и А. Кламера). Гонсалес (следуя теории социального конструирования профессий, выдвинутой Л. Болтански) рассматривает медленный и незавершенный процесс институционализации профессии экономиста, контрастирующий со стремительным ростом ее символического статуса. Позднее, в 1998 г. «Социус» организовал Первый Португальский Конгресс по проблемам экономической социологии, который собрал около шестисот участников. В качестве основных докладчиков выступили отечественные и зарубежные исследователи.

\section{Прочие темы исследований}

Социологию труда и индустриальную социологию нельзя полностью отнести к «экономической социологии», однако они, несомненно, образуют наиболее близкую к ней область, причем эта область прочно институционализирована в португальской социологии. Здесь работают образовательные программы разных уровней, присваиваются ученые степени, издаются специальные журналы, постоянно ведутся исследования,

\footnotetext{
${ }^{5}$ Среди других важных исследований, выполненных в «Социусе», - работа Илоны Ковач [Ilona Kovács] о новых моделях производства и организации труда; Марии да Консейсау Сердейра [Maria da Conceição Cerdeira] об индустриальных отношениях; Хелены Серра [Helena Serra] о властных отношениях между врачами и медперсоналом в сфере здравоохранения; Софии Бенту [Sofia Bento] o социальных противоречиях, порождаемых новыми технологиями; Сары Фалкау Касака [Sara Falcão Casaca] o гендерной дискриминации на рынке труда и гибкой занятости; Хелены Жерониму [Helena Jerónimo] о науке, этике и религии.
} 
организовываются семинары, действует профессиональная ассоциация (Португальская Ассоциация индустриальной социологии, социологии труда и организаций - APSIOT). В отличие от экономической социологии, эта область уже являлась предметом обзоров, которые делались разными авторами [Rodrigues and Lima 1987; Stoleroff 1992a and 1992b; Ferreira and Costa 1998.1999; Freire 2000]. Все авторы, описывающие португальскую социологию, признают, что индустриальная социология - одно из самых сильных ее направлений; это также одно из самых старых направлений, хотя здесь проводят различие между социологией труда как более зрелой областью и социологией организаций, появившейся позднее. По поводу точного времени возникновения этого направления мнения расходятся. Одни утверждают, что вопросы труда и трудовых отношений были в центре внимания еще в 1960-е гг. [Rodrigues and Lima 1987]. Другие считают 1974 год переломным моментом для этой области: именно тогда в ней появились новые исследовательские темы и теоретические направления [Stoleroff 1992a].

В рамках данной области изучались разные темы. Сразу после 1974 г. это были прежде всего рабочий класс и его требования, профсоюзное движение и политические связи. В этот период был наиболее развит подход, основанный на марксистском структурализме и теории действия (в значительной степени - под влиянием А.Турена). Предметом исследования выступали также инициативы коллективных действий и самоуправления, отношения между технологией, организацией труда [labour organization] и процессом формирования навыков, история рабочего движения. В 1980-е гг. начали появляться новые темы. Среди них - занятость, безработица, увеличение гибкости [flexibilization] трудовых отношений [например, Rodrigues 1998], технологические изменения (в том числе новые информационные технологии), организация труда [work organization], квалификационная структура, профессиональное обучение, модели производства (техноцентричные и антропоцентричные [Kovács and Castillo 1998]), неравенство на рынке труда (в том числе, его гендерные аспекты), институциональное регулирование трудовых отношений и социология профессий. Среди наиболее заметных авторов, исследующих эти направления, - Жуау Фрейре, Илона Ковач, Антониу Брандау Мониш [António Brandão Moniz], Жозе Баптиста [José Baptista] (в частности, его поздние работы), Мария Филомена Моника [Maria Filomena Mónica], Мария Жуау Родригеш [Maria João Rodrigues], Мартинуш Пиреш де Лима [Martinús Pires de Lima], Мария Тереза Роза [Maria Teresa Rosa], Мария да Консейсао Сердейра, Алан Столерофф [Alan Stoleroff] и Мария де Лурдеш Родригеш [Maria de Lurdes Rodrigues].

Активная работа велась и в рамках других исследовательских направлений. Во-первых, это касается изучения неформальной экономики. Исследования начала 1980-х гг. показали, что неформальная или скрытая хозяйственная деятельность в стране весьма распространена. Полученные данные были просто поразительны: макроэкономические индикаторы говорили о глубоком кризисе, а уровень потребления и благосостояния людей возрастал. Одним из первых к изучению этой проблемы обратился Мануэль Виллаверде Кабрал [Manuel Villaverde Cabral 1983]. Анализируя различные индустриализированные сельские районы, он обнаружил, что акторы сочетают стратегии работы в рамках городского и промышленного рынков труда с частичной занятостью в фермерском хозяйстве и получением социальных пособий. Он утверждает, что «... сельская местность чрезвычайно богата стратегиями, которые макроэкономика не могла предвидеть» [Cabral 1983: 222]. Позднее Исабель Лобо приложила данный подход к анализу других сфер и также выявила связь социальных и экономических структур с неформальной экономикой 
и факт вовлеченности акторов - предпринимателей, рабочих и их семей - в неформальные виды деятельности [Lobo 1985]. Некоторые другие социологи и экономисты (в том числе Мария Жуау Родригес) также исследовали эту проблему.

Во-вторых, совместными усилиями социологов, экономистов и географов развивалась смежное направление: исследование территориальных контекстов производства. Эти авторы ставили своей задачей выявить региональные и местные особенности способов производства, регулирования и потребления. Здесь можно выделить исследования Боавентуры де Соза Сантоша [Boaventura de Sousa Santos] и Жозе Pейса [José Reis] (Университет Коимбры), а также Фернанду Медейроша [Fernando Medeiros] (Университет Парижа и Институт экономического и делового администрирования [ISEG]) [Santos 1985; Reis 1992; Medeiros 1992]. Сантош выполнил сравнительный анализ различных региональных индикаторов и показал, что капиталистический способ производства не всегда сопровождался формой социального воспроизводства, основанной на наемном труде. Различные стратегии трудового найма сочетались с частичной занятостью в сельском хозяйстве, просьбами о финансовой помощи (в частности, в случае эмигрантов обращениями к родственникам прислать деньги из дома) и получением социальных пособий (сохраняя при этом свою территориальную специфику). Рейс, экономист по образованию, исследовал локальную систему производства в центральной части прибрежных районов Португалии, взяв за основу традицию изучения индустриальных районов. Вскоре после этого он провел исследование связей между государством и экономикой [Reis 1997]. Медейрош предпринял попытку теоретически обобщить особенности южноевропейских стран, определив их как «общества со множеством пространств» [societies of multiple spaces] и различными формами социальной и экономической локальной структурации. Среди других авторов, занимавшихся изучением данной проблемы, следует упомянуть Жуау Феррау [Јоão Ferrão] и Родериу Роке Амару [Rodério Roque Amaro].

В-третьих, сложилась определенная традиция исследования экономических элит и предпринимательства. Начало ей еще в 1960-е гг. положила новаторская работа Харри Маклера о «промышленной элите» в Португалии (за основу взят текст его диссертации в Колумбийском университете в 1968 г.) [Makler 1969]. Он исследовал социальные характеристики агентов, управляющих крупными производственными предприятиями, их профессиональные навыки, анализировал традиционный и «менеджериальный» [managerial] подходы к изучению фирмы. В конце 1980-х гг. исследования Мануэлы Силва [Manuela Silva], Марии даш Дореш Геррейру [Maria das Dores Guerreiro], Аны Нунеш де Алмейда [Ana Nunes de Almeida], Жуау Феррау, Жозе Мануэля Собрала [José Manuel Sobral] и др. придали направлению новый импульс [Silva 1989; Guerreiro 1996; Almeida, Ferrão, Sobral 1994]. Силва и ее соавторы провели исследование предпринимателей и менеджеров в обрабатывающей промышленности и проанализировали их различные характеристики, установки и поведение. Геррейру исследовала мелкие фирмы и отношения между деловыми и семейными стратегиями. Алмеда, Феррау и Собрал применили комбинированный подход к изучению предпринимательства, объединив в одной аналитической схеме пространство, социальные классы и семью. Дальнейшие исследования в этом направлении велись также Марией Филомена Моника [Maria Filomena Mónica], Нельсоном Лоренсу [Nelson Lourenço], Мануэлем Лижбоа [Manuel Lisboa] и Мафалдой Кардим [Mafalda Cardim]. 
Наконец, следует упомянуть некоторые другие направления работы - уже сложившиеся и появившиеся относительно недавно. Среди них - исследования посреднических институтов (организаций третьего сектора) и социального исключения (здесь работают такие авторы, как Жозе Перейринья [José Pereirinha], Карлош Баррош [Carlos Barros], Амилкар Морейра [Amílcar Moreira], Паулу Вариш [Paulo Variz]); исследования государства и коллективного действия (Паулу Тригу Перейра [Paulo Trigo Pereira]); институционального регулирования экономики (Мануэль де Лусена [Manuel de Lucena], Карлош Гаспар [Carlos Gaspar], Мария Мануэль Лейтау Маркеш [Maria Manuel Leitão Marques], Антониу Казимиру Ферейра [António Casimiro Ferreira]); исследования проблем развития (Йохен Оппенхаймер [Jochen Oppenheimer] и его коллеги из Центра исследований Африки и развития, а также Института экономического и делового администрирования - ISEG); исследования ценностей, установок и развития (Мануэль Виллаверде Кабрал); международной миграции, политики и рынков труда (Мария Иоанниш Баганья [Maria Ioannis Baganha]); хозяйства и социологии культуры (Карлош Баррош [Carlos Barros], Педру Кошта [Pedro Costa], Жуау Тейшейра Лопеш [João Теixeira Lopes], Эдуарду Эшперанса [Eduardo Esperança] и Мария де Лурдеш Лима дош Сантош [Maria de Lurdes Lima dos Santos]); исследования потребления (Кристина Матош [Сristina Matos] и Жозе Пейшото Визе [José Peixoto Viseu]); социальных форм использования времени (Эмилия Араужу [Emília Araújo]). И в заключение хотелось бы отметить, что несмотря на упомянутые институциональные дилеммы, экономическая социология и смежные с нею области имеют в Португалии многообещающее будущее.

\section{Библиография}

Almeida, Ana Nunes, João Ferrão and José M. Sobral, "Territórios, empresários e empresas: entender as condições sociais da empresarialidade" ("Territories, entrepreneurs and firms: the social foundations of entrepreneurship"), Análise Social (1994). Vol. 29, No. 125126. Pp. 55-79.

Cabral, Manuel Villaverde, “A economia subterrânea vem ao de cima: estratégias da população rural perante a industrialização e a urbanização" ("Informal economy arises: rural population strategies towards industrialisation and urbanisation"), Análise Social (1983). Vol. 19, No/ 76. Pp. 199-234.

Cuisennier, Jean, "Instrumentos e tarefas para uma sociologia da economia" ("Tasks and tools for a sociology of the economy”), Análise Social (1965). Vol. 3, No. 9-10. Pp. 103-116.

Ferreira, António Casimiro and Hermes A. Costa, "Para uma sociologia das relações laborais em Portugal" ("For a sociology of labour relations in Portugal"), Revista Crítica de Ciências Sociais (1998/1999). No. 52-53. Pp. 141-171.

Ferreira, J. M. Carvalho, Rafael Marques, João Peixoto and Rita Raposo (Org.) (1996), Entre a Economia e a Sociologia (Between Economics and Sociology), Oeiras, Celta Editora.

Freire, João, "Uma economia mais democrática? - Nota de pesquisa" ("A more democratic economy? - Research note”), Sociologia - Problemas e Práticas (1991). No 9. Pp. 161166. 
Freire, João. "Companies and organisations: change and modernisation", in: A. F. Costa and J. M. Viegas (eds.), Crossroads to Modernity - Contemporary Portuguese Society. Oeiras: Celta Editora, 2000.

Guerreiro, Maria das Dores, Famílias na Actividade Empresarial - PME em Portugal (Families and Firms - SME in Portugal). Oeiras: Celta Editora, 1996.

Kovács, Ilona, "Economia e sociologia na era da incerteza: do conflito à cooperação" ("Economics and sociology in the uncertainty era: from conflict to co-operation"), Estudos de Economia (1985). Vol. 5, No. 4. Pp. 441-451.

Kovács, Ilona and Juan José Castillo, Novos Modelos de Produção - Trabalho e Pessoas (New Models of Production - Work and People). Oeiras: Celta Editora, 1998.

Lobo, Isabel de Sousa, "Estrutura social e produtiva e propensão à subterraneidade no Portugal de hoje" ("Social and productive structure and propensity to informality in contempoary Portugal”), Análise Social (1985). Vol. 21, No. 87-88-98. Pp. 527-562.

Makler, Harry Mark, $A$ «Elite» Industrial Portuguesa (The Portuguese Industrial Elite). Lisbon: Fundação Calouste Gulbenkian, 1969.

Marques, Rafael and Peixoto, João, Nova Sociologia Económica - Uma Antologia (New Economic Sociology - An Anthology). Oeiras: Celta Editora, forthcoming.

Medeiros, Fernando, “A formação do espaço social português: entre a «sociedade-providência» e uma CEE providencial" ("The constitution of the Portuguese social space: between a «welfare society" and a «providential EEC»"), Análise Social (1992). Vol. 27, No. 118119. Pp. 919-941.

Moreira, José Manuel, "Crise económica e (cons)ciência económica" ("Economic crisis and economic (con)science”), Cadernos de Ciências Sociais (1986). No. 4. Pp. 139-154.

Nunes, João Arriscado, “A poética e a política da ciência económica: para uma sociologia da economia" ("Poethic and politics of economic science: for a sociology of economics"), Notas Económicas (1994). No. 2. Pp. 98-108.

Nunes, João Arriscado, “A «ciência dos recursos naturais» e a reconversão da economia: zonas de transacção e objectos de fronteira" ("The «natural resources science» and economic revamping: zones of transaction and frontier objects"), Oficina do CES (April 1998), No. 109.

Reis, José, Os Espaços da Indústria: a Regulação Económica e o Desenvolvimento Local em Portugal (The Industry's Spaces: Economic Regulation and Local Development in Portugal). Porto: Afrontamento, 1992.

Reis, José, "O Estado e a economia: novas e velhas questões" ("State and economy: new and old questions"), Sociologia - Problemas e Práticas (1997). No. 21.

Rodrigues, Maria João, O Sistema de Emprego em Portugal: Crise e Mutações (The Employment System in Portugal: Crisis and Mutations). Lisbon: Dom Quixote, 1988.

Rodrigues, Maria João and Marinús Pires de Lima, "Trabalho, emprego e transformações sociais: trajectórias e dilemas das ciências sociais em Portugal" ("Work, employment and social change: social sciences' paths and dilemmas in Portugal"), Análise Social (1987). Vol. 23, No. 95. Pp. 119-149. 
Santos, Boaventura de Sousa, "Estado e sociedade na semiperiferia do sistema mundial: o caso português" ("State and society in the semi-periphery of the world system: the Portuguese case”), Análise Social (1985). Vol. 21, No. 87-88-89. Pp. 869-901.

Silva, Manuela (Coord.) et al., Empresários e Gestores da Indústria em Portugal (Entrepreneurs and Industrial Manufacturing Managers in Portugal), 2 vol. Lisbon : CISEP / UTL Instituto Superior de Economia, 1989.

Stoleroff, Alan (a), "Sobre a sociologia do trabalho em Portugal" ("On sociology of work in Portugal”), Sociologia - Problemas e Práticas (1992). No. 11. Pp. 135-150.

Stoleroff, Alan (b), "Sobre a sociologia do trabalho em Portugal: evolução e perspectiva" ("On sociology of work in Portugal: trends and forecasts"), Sociologia - Problemas e Práticas (1992). No. 12. Pp. 155-169.

VVAA, "Aspectos sociais do desenvolvimento económico em Portugal" ("Social aspects of economic development in Portugal”), Análise Social (1964). Vol. 2, No. 7-8. 
$\boldsymbol{V} \boldsymbol{R}$ Это первый обзор, в котором поиск ресурсов осуществлялся целевым образом по определенным темам. Выбраны три темы: классические тексты, история и методология экономической социологии, социальная стратификация. В дальнейшем мы предполагаем продолжить тематическую - систему поиска и подготовить серию обзоров в соответствии c разработанным нами оригинальным предметным каталогом по экономической социологии.

$$
\text { Обзор интернет-ресурсов - } 6
$$

\title{
КЛАССИКА ЭКОНОМИЧЕСКОЙ СОЦИОЛОГИИ, ИСТОРИЯ И МЕТОДОЛОГИЯ ЭКОНОМИЧЕСКОЙ СОЦИОЛОГИИ, СОЦИАЛЬНАЯ СТРАТИФИКАЦИЯ
}

\section{Новикова Елена Геннадьевна}

аспирант Государственного университета - Высшей школы экономики

\author{
Email: neg@msses.ru
}

В данном обзоре мы представим первую подборку ссылок на англоязычные тексты по экономической социологии, разбив их на темы.

В русскоязычном web-пространстве электронные «хранилища» книг зачастую представляют собой отдельные сайты, не относящиеся к исследовательским или учебным институтам. Тексты в них размещаются как с соблюдением авторских прав, так и в обход их, и, как правило, представляют собой отсканированные книги или статьи.

В англоязычном Интернете принципы организации хранения текстов несколько другие. Во-первых, электронных библиотек с собранием полнотекстовых книг намного меньше, чем можно было бы ожидать от Всемирной сети. Кроме того, в подобных библиотеках хранятся только тексты давно умерших классиков (поскольку наши западные коллеги более ответственно относятся к авторским правам). Если же вы ищете тексты ныне живущих исследователей, то вам в первую очередь следует обратиться к сайтам университетов, в которых они преподают. Практически на любом университетском сайте есть подборка working papers. Кроме этого, многие исследователи выкладывают на своих персональных страницах тексты, уже опубликованные в ведущих журналах. Заметим, что и хранилища классических текстов, как правило, «привязаны» к университетским сайтам.

Итак, в англоязычном Интернете доступны полные тексты нескольких классических книг, имеющих непосредственное отношение к экономической социологии. Прежде всего, это «Протестантская этика и дух капитализма» Макса Вебера:

http://www.ne.jp/asahi/moriyuki/abukuma/weber/world/ethic/pro_eth_frame.html

Здесь вы найдете то, что называется виртуальной книгой с перекрестными ссылками и прочими дополнительными возможностями. Пожалуй, эстетическая красота данной книги оставляет желать лучшего, но удобство пользования налицо. Эта же книга в обыкновенном html формате: http://xroads.virginia.edu/ HYPER/WEBER/toc.html

Кроме этого, в Интернете можно обнаружить следующие тексты.

Hayek, Freidrich. Economics and Knowledge, Economica IV (new ser., 1937), p. 33-54:

http://www.virtualschool.edu/mon/Economics/HayekEconomicsAndKnowledge.html 
Menger, Carl. On the Origins of Money, Economic Journal (1892). Vol. 2. P. 239-255. (translated by C.A. Foley):

http://socserv2.socsci.mcmaster.ca/ econ/ugcm/3113/menger/money.txt

Schumpeter, Joseph. On the Concept of Social Value, Quarterly Journal of Economics (1908-9). Vol. 23. Pp. 213-232: http://www.socsci.mcmaster.ca/econ/ugcm/3113/schumpeter/socialval.html

Schumpeter, Joseph. Capitalism, Socialism, and Democracy. N.Y.: Harper and Row, 1942. Pp. 235-249,263-289: http://www.spc.uchicago.edu/ssr1/NEWPRE/POLSOC98/Schump.html

Veblen, Thorstein. The Theory of the Leisure Class:

http://socserv2.socsci.mcmaster.ca/ econ/ugcm/3113/veblen/leisure/index.html

Weber, Max. Characteristics of Bureaucracy, Economy and Society. Part III, Ch. 6. Pp. 650-678: http://wizard.ucr.edu/ bkaplan/soc/lib/webrbur2.html

Weber, Max. The Types of Legitimate Domination. (summary):

http://www.stanford.edu/ mmorten/OTWeb/summaries/gsb/content/Weber2.html

Также хотим обратить внимание на тексты, не имеющие к экономической социологии прямого отношения, но, тем не менее, безусловно, важные:

DiMaggio, Paul. Culture as Cognition, Annual Review of Sociology (1997). Vol. 23. P. 263-288: http://cogweb.ucla.edu/Abstracts/DiMaggio_97.html

Latour, Bruno. When things strike back - a possible contribution of science studies. http://www.ensmp.fr/ latour/Articles/78-sciencestudies.htm

Malinowski, B. The Primitive Economics of the Trobriand Islanders, Economic Journal (1921), Vol. 31. P. 1-16: http://www.socsci.mcmaster.ca/econ/ugcm/3113/malinowski/prim

Maslow, A. H. A Theory of Human Motivation, Psychological Review/ Vol. 50. Pp. 370-396. http://psychclassics.yorku.ca/Maslow/motivation.htm

На персональной странице Амитаи Этииони (http://www.gwu.edu/ ccps/etzioni/index.html) доступны многие его публикации, среди которых для экономсоциологов первоочередной интерес могут представлять следующие работы ${ }^{1}$ :

Etzioni, Amitai. A Socio-Economic Perspective on Friction, in: Sjostrand, Sven-Erik (ed.) Institutional Change, Theory and Empirical Findings. N.Y.: M.E. Sharpe, Inc., 1993. Also published in: Futures Research Quarterly (Summer 1993). Vol. 9, No. 2. Pp. 5-22.

Etzioni, Amitai. Dual Leadership in Complex Organizations, American Sociological Review (1965). Vol. 30, No. 5. Pp. 688-698. (в формате pdf)

Etzioni, Amitai. The Socio-Economics of Work, in: Gamst, Frederick C. (ed.) Meanings of Work, Considerations for the Twenty-First Century. Albany: SUNY Press, 1995. Pp. 251260.

\footnotetext{
${ }^{1}$ См. также работу А. Этциони «Социоэкономика: дальнейшие шаги» в нашем журнале
} (2002, T. 3, № 1. С. 65-71) . 


\section{История и методология экономической социологии}

Интернет предоставляет нам уникальную возможность познакомиться с трудами «живых классиков» экономической социологии. Как правило, это выступления на различных конференциях, которые в дальнейшем легли в основу публикаций. Работы по методологии и истории экономической социологии самых известных исследователей в данной области размещены на следующих сайтах:

http://www.gsm.uci.edu/econsoc/essays.html (Economic Sociology Editorials)

Baker, Wayne E. Bridging the Philosophical Divide Between Sociology and Economics.

Biggart, Nicole Woolsey. Conventional Wisdom: Efficiency and Social Customs.

Collins, Randall. The Multiple Fronts of Economic Sociology.

Swedberg, Richard. What is Happening in Economic Sociology?

Zelizer, Viviana. Next Steps in Economic Sociology.

http://socrates.berkeley.edu/ iir/culture/papers.html (Center for Culture, Organizations, and Politics. Institute of Industrial Relations, University of Berkley. Working Papers)

Beckert, Jens. Economic Action and Embeddedness: The Problem of the Structure of Action.

Granovetter, Mark. A Theoretical Agenda for Economic Sociology.

См. также:

Granovetter, Mark. Economic Action and Social Structure: The Problem of Embeddedness. (summary):

http://www.stanford.edu/ mmorten/OTWeb/summaries/mse/content/Granovetter.html

Heckathorn, Douglas D. The Paradoxical Relationship Between Sociology and Rational Choice, The American Sociologist (1997). Vol. 28, No. 2. Pp. 6-15:

http://www.people.cornell.edu/pages/ddh22/as.html

Следующий текст Ричарда Сведберга и Марка Грановеттера представляет собой краткий, но довольно основательный экскурс в историю экономической социологии, а также очерчивает в общих чертах ее методологию:

Swedberg, Richard and Mark Granovetter. Introduction, in: Granovetter, Mark and Richard Swedberg (eds.) The Sociology of Economic Life. Boulder, CO: Westview Press, 2001. Pp. 1-28: http://www.soc.cornell.edu/research/swedgranintro.html 


\section{Социальная стратификация}

(a) Классические концепции и методологические работы

Chamberlain, John Martin. Marx and Weber: A Comparison of Views on Industrial Society: http://www.sspp.net/archive/papers/1(1)chamberlain.htm

Davis, Kingsley and Wilbert Moore. Some Principles of Stratification (with a response by Melvin Tumin): http://www.soc.iastate.edu/sapp/soc130.cr08.html

Engels, Fridrich. Social Classes - Necessary and Superfluous. http://www.marxists.org/archive/marx/works/1881/08/06.htm

Grusky, David B. Weeden, Kim A. and Jesper B. Sørensen. The Case for Realism in Class Analysis: http://www.inequality.com/publications/working papers/Grusky1.pdf

Grusky, David B. Social Stratification:

http://www.inequality.com/publications/working_papers/Grusky2.pdf

Volsch, Thomas William. Marxist Concepts of Exploitation and Inequality: http://www.sspp.net/archive/papers/4(2)volscho.htm

Weber, Max. Class, Status, Party. (summary):

http://www.spc.uchicago.edu/ssr1/PRELIMS/Theory/weber.html

Wright, Erik Olin. The Shadow of Exploitation in Weber's Class Analysis: http://www.ssc.wisc.edu/ wright/weber.pdf

Персональная страница Эрика О. Райта: http://www.ssc.wisc.edu/ wright/papers.html

Помимо таких работ, как «Foundations of Class Analysis» (1999), «Class, Exploitation and Economic Rents: reflections on Sørensen's», «Toward a Sounder Basis for Class Analysis», «The Glass Ceiling Hypothesis: A Comparative Study of the United States, Sweden, and Australia», Alternative Foundations of Class Analysis, edited by Erik Olin Wright ${ }^{2}$, на сайте вы найдете его учебные программы, полную библиографию и интервью. Важно, что данная страница относительно регулярно пополняется.

(б) Проблемы современных исследований стратификации http://www.inequality.com/publications/working_papers.shtml (Working Papers of Center for the Study of Inequality)

Работы, размещенные на данном сайте, можно условно поделить на следующие темы: гендер и неравенство; этничность и неравенство; образование и неравенство; неравенство на рынке труда.

Следующие тексты хранятся на персональных страницах социологов.

Balazs, Vedres. «Econocratic» manager-elite - The Winners of the Transformation? The changing value of the economic and technical qualification in the business elite: http://www.columbia.edu/ bv2002/pages/papers/pdf/econocrat.pdf

\footnotetext{
${ }^{2}$ В этой книге недоступны 3 и 4 главы.
} 
Chiu, Charlotte. The Division of Housework Among Interracial Couples: http://www.sspp.net/archive/papers/1(1)chiu.htm

Ding, Ning. The Intellectual Class: The Third Class in Modern Society: http://www.sspp.net/archive/papers/1(1)ding.htm

Heath, Anthony F. and Dorren McMahon. Ethnic Differences in the Labour Market: The Role of Education and Social Class Origins: http://www.sociology.ox.ac.uk/swps/2000-01.pdf

Weeden, Kim A. Why do Some Occupations Pay More than Others? Social Closure and Earnings Inequality in the United States: http://www.people.cornell.edu/pages/kw74/postasa3rev6.pdf

Weeden, Kim A. and Jesper B. Sørensen. Industrial and Occupational Sex Segregation in the United States, in Charles, Maria and David B. Grusky (eds.) Sex Segregation in Comparative Perspective:

http://www.people.cornell.edu/pages/kw74/industrysexseg.pdf

Однако не всегда удается обнаружить полный текст какой-либо книги. В таком случае неоценимую помощь может оказать ее краткое изложение/резюме (summary). Достаточно основательные резюме важнейших работ по социальной стратификации вы найдете здесь:

http://www.spc.uchicago.edu/ssr1/PRELIMS/Strat/stmisc2.html

Granovetter, Mark. Toward a Sociological Theory of Income Differences.

Giddens, Anthony. Classes, Power, and Conflict.

Hout, Michael. Status, Autonomy, and Training in Occupational Mobility.

Parkin, Frank. Marxism and Class Theory: A Bourgeois Critique.

Tumin, Melvin. Some Principles of Stratification: A Critical Analysis.

White, Harrison C. The Logic of Opportunity.

http://www.spc.uchicago.edu/ssr1/PRELIMS/Strat/stmisc1.html

Baron, James. Organizational Perspectives on Stratification.

Blau, Peter. Inequality and Heterogeneity.

Bourdieu, Pierre. Distinction - «The Sense of Distinction» (Ch. 5)

Dahrendorf, Ralf. Class and Class Conflict in Industrial Society.

Devis, K. and W. Moore. Some Principles of Stratification.

Giddens, Anthony. Class Structuration and Class Consciousness.

Goldthorpe, John H. Social Mobility and Class Structure in Modern Britain.

Horan, Beck and Tolbert. Stratification in a Dual Economy.

http://www.spc.uchicago.edu/ssr1/PRELIMS/Strat/stadd.html

Becker, Gary. From Human Capital (Chapter 2 - 'On-the-job Training')

Blaug, Mark. The Empirical Status of Human Capital Theory: A Slightly Jaundiced Survey.

Cohen, G.A. The Economic Structure, from Karl Marx's Theory of History. 
http://www.spc.uchicago.edu/ssr1/PRELIMS/Strat/stadd2.html

Kondo, Dorinne K. Crafting Selves: Power, Gender, and Discourses of Identity on a Japanese Workplace (Chs. 3, 6).

Moi, Toril. Appropriating Bourdieu's Feminist Theory and Pierre Bourdieu's Sociology of Culture.

Rokkan, Stein. Dimensions of State Formation and Nation Building: A Possible Paradigm for Research on Variations in Europe.

Turner, Ralph H. Sponsored and Contest Mobility and the School System.

Zelizer, Viviana A. The Social Meaning of Money: 'Special Monies'. 


\title{
Новые книги
}

$\boldsymbol{V} \boldsymbol{R}$ Предлагаем вашему вниманию рецензию С.Ю.Барсуковой на книгу, опубликованную ранее в журнале «Pro et Contra» [Том 6, № 3, лето 2001]. Обычно мы не размещаем уже опубликованные тексты. Но в данном случае (с любезного согласия руководства журнала) мы делаем исключение. Ибо рецензии, выходящие за дежурно-повествовательные рамки, пишутся у нас, увы, нечасто.

\section{Клямкин И., Тимофеев Л. Теневая Россия: Экономико-социологическое исследование. М.: РГГУ, 2000. 595 с.}

\section{Барсукова Светлана Юрьевна}

\author{
к. с. н., Государственный университет - Высшая школа экономики \\ Email: cvbars@mail.ru
}

В последнее время заметно вырос интерес к проблемам теневой экономики. Правда, обилие публикаций на эту тему не компенсирует отсутствия системного взгляда на явление. На этом фоне выход в свет объемистой книги о «тени» не мог остаться незамеченным. Ее авторы, судя по всему, поставили перед собой цель восполнить дефицит системного ве́дения, предложив читателю сочетание разнообразной эмпирики c еe теоретической интерпретацией. Провозгласив, что теневой экономике присуща собственная логика функционирования и развития, они пытаются эту логику выявить и выстроить. А это - задача едва ли не революционного масштаба.

Эмпирическая панорама, нарисованная авторами, впечатляет разнообразием сюжетов и тематических разделов. Здесь и коррупция государственного аппарата, и поборы правоохранительных органов, и взяточничество в высшей школе, и теневой рынок медицинских услуг, и теневое предпринимательство, и теневое кредитование, и теневые операции с земельной собственностью, и рынок освобождения от воинской обязанности. Собранный материал изложен и интерпретирован в четырех главах. Первые две написаны по материалам интервью и посвящены теневой экономике соответственно деревни и города (111 интервью). На их основе сделан вывод, что зарождающийся в теневой сфере экономический уклад имеет значительный потенциал и что «любые попытки обуздать эту нелегальную рыночную стихию методом административного нажима могут принести только вред и обернуться очередным движением вспять» [с. 83]. Единственный реальный выход - это «легализация деятельности неформалов... посредством предоставления им льготных условий существования» [с. 207], ведущая от теневого порядка к правовому. Вывод вполне в духе либеральных рецептов.

В третьей главе приведены количественные оценки распространенности теневых операций и проанализировано отношение к ним разных групп населения (общероссийская репрезентативная выборка, 1600 опрошенных). Респонденты поделены на предпринимателей, непредпринимателей и предпредпринимателей (терминология авторов), что позволяет соотнести различные типы сознания - 
юридически-правовой, неправовой (коррупционно-теневой) и доправовой (моральнорепрессивный) - с ориентацией на занятие бизнесом либо с отсутствием таковой. В частности, авторы выясняют, что импульс законопослушания исходит от мелких предпринимателей, разочаровавшихся в союзе с чиновничеством. Такая же ориентация, как предполагается, будет свойственна и предпредпринимателям по мере их вхождения в мир бизнеса. Так что перспективы выглядят довольно оптимистично. Однако «чтобы такой процесс пошел активно, сам бизнес должен стать экономически сильным и независимым от власти» [с. 236]. Правда, не очень ясно, благодаря каким социальным и политическим силам это может произойти - ведь сами предприниматели составляют порядка пяти процентов в структуре современного российского общества да и в политической активности особо не замечены.

Данная, третья, глава содержит обширный массив упорядоченных данных, сопровождаемых авторскими комментариями, которые претендуют, хотя и в разной мере, на новизну и оригинальность в трактовке проблем теневой экономики. Для человека, умеющего «читать» таблицы, количественные данные самодостаточны и процесс чтения книги ускоряется за счет пропуска части текста. Впрочем, это - общее свойство работ описательного характера, и умение приводить эмпирику в формат «самоговорящих» таблиц свидетельствует о профессионализме авторов.

В четвертой главе прослежена связь между теневыми установками и политическими предпочтениями россиян; в очередной раз найдено подтверждение того, что экономические и политические ориентации могут не совпадать, хотя это не значит, что между ними нет никакой взаимосвязи. Зафиксирован также преобладающий тип сознания - морально-репрессивный, что может стать ограничителем экономикоправовых стратегий борьбы с «тенью».

И, наконец, в заключительной части книги, на которую приходится чуть менее половины ее объема, опубликованы «голоса из тени» - полномасштабные углубленные интервью, собранные авторами в ходе исследования. Сам факт обилия столь откровенных интервью свидетельствует о широком распространении и обыденности теневых отношений в нашей жизни, а также о мере их фактической легитимации.

Как видно из вышесказанного, авторы изучают теневую экономику, пронизывающую повседневную жизнь россиян, принципиально отказываясь от сведения ее к отдельным хозяйственным локусам. Это более чем разумно, поскольку главная примета современной России в том, что всякая демаркация между теневой и легальной деятельностью в ней условна.

Поскольку книга заявлена как попытка восхождения от эмпирики к теории, возникает законный вопрос: каковы же теоретические воззрения авторов?

По их мнению, пришедшее с Запада понятие «неформальная экономика» не соответствует российской действительности, ибо в нынешних российских условиях оно «вряд ли может быть распространено дальше представлений о домашнем хозяйстве и об индивидуальной предпринимательской деятельности» [с. 10]. Отсюда - призыв использовать понятие «теневая экономика». Не оспаривая свободу авторов в выборе терминов, замечу только, что в западной традиции, которая утвердилась и в российской науке, под неформальной экономикой понимают агрегированный феномен как противоправных, так и внеправовых хозяйственных трансакций во всем их разнообразии, включая блат и коррупцию. При таком понимании теневую экономику 
принято считать сегментом неформального пространства, ее значительным смысловым разворотом. Аргументация авторов против понятия «неформальная экономика» явно недостаточна для серьезной заявки на терминологическую инновацию.

Для книги вообще характерны попытки опротестовать западные каноны применительно к российской «тени». По мнению авторов, теневая экономика России опровергает западные представления об истоках возникновения и закономерностях функционирования внелегальной практики. Если на Западе неформальная деятельность существует как «независимая частная инициатива за пределами действующего закона» и прекращается с обретением ею правового статуса, то в России официальный правовой статус «предшествует выходу оператора на нелегальный рынок» [с. 11]. По отношению к Западу это - довольно смелое утверждение. Сильно сомневаюсь, что западная литература может быть сведена к столь простым понятийным схемам. Социальноэкономические теории коррупции, кстати западные по происхождению, учитывают официальный статус субъекта как фактор его включенности в теневые операции. Да и нет единой западной версии причин и логики развития теневой экономики. Помимо разных научных школ существует еще дифференциация подходов применительно к развитым и развивающимся странам, а также к странам с переходной экономикой.

В силу «перетаскивания нерыночных статусных возможностей» в рыночную «тень» возникает теневое парагосударство, понимаемое авторами как приватизированное. «Такое государство тем-то и отличается от государства легального и конституционного, что функции, которые должны быть исключены из рыночного оборота (например, функции суда или армии), утрачивают характер общественного блага и становятся предметом купли-продажи» [с. 12]. Следовательно, считают Клямкин и Тимофеев, в зоне «тени» понятия «государство» и «рынок» совпадают. Замечу в этой связи, что в последнее время участились попытки определять роль и сущность теневой экономики через апелляцию к понятию государства. Здесь и «уголовно-государственный паритет» (Вадим Радаев), и «фрагментация российской государственности в результате множественности очагов насилия» (Вадим Волков) и т. п. Версия авторов книги стоит в ряду гипотез о корреляции процессов теневизации экономики с состоятельностью государственной власти. Жаль только, что Клямкин и Тимофеев не сочли нужным обозначить качественную специфику своих взглядов относительно позиций других исследователей.

Вообще авторы не особенно жалуют работы своих предшественников. Часто упоминаемая западная традиция, которая, по мнению авторов, несостоятельна для объяснения российской «тени», представлена всего шестью именами, да и то больше «через запятую», без анализа эвристического потенциала упоминаемых работ. Российским коллегам повезло ненамного больше. Внимание авторов книги привлекли всего восемь работ, включая сочинения одного из авторов. Правда, есть еще несколько отсылок к газетным заметкам, но публицистика, давая оперативные и эмоциональные зарисовки жизни, вряд ли способна стать серьезным слагаемым научной концепции.

Впрочем, теория - вещь капризная. Она невозможна вне дисциплинарных, методологических и дискурсивных координат. Теневая экономика с позиций неоинституционализма выглядит иначе (с точки зрения возникновения, функций и возможностей легализации), чем с позиций, скажем, неоклассической теории. Социологические трактовки также имеют свои традиции, категориальный аппарат и концептуальные схемы, внимание к которым не просто дань авторам, чьи идеи 
получили признание, но и показатель включенности в «незримый колледж», наделенный правом «организованного скептицизма» (Роберт Мертон) по отношению к новым суждениям. Понимаю, что рассуждения такого рода могут показаться занудством. Но наука требует соблюдения технологии, иначе она вырождается в публицистику. Принадлежность к цеху обязывает. Объекты анализа не делятся на те, что достойны науки, и те, что составляют привилегию публицистики. Водораздел между научным и ненаучным лежит в области методологии. Вписанность исследования в поле трудов предшественников - непременный атрибут научного производства.

Авторы не один раз отмечают слабую изученность темы, за которую они взялись. Но ситуация быстро меняется. Теневая экономика из недавно еще табуированной области знания буквально на глазах превращается в одну из самых конъюнктурно востребованных. Еще вчера про «тень» молчали даже те, кому было что сказать. Сегодня говорят и те, кому сказать нечего. Поэтому «белым пятном» ее назвать трудно. По крайней мере, эмпирические доказательства ее существования уже не способны ни удивить, ни озадачить. Другое дело, что по-прежнему в дефиците системный анализ этого явления. И выход в свет книги «Теневая Россия» мог бы стать революционным событием для научного мира и общественности, появись она на несколько лет раньше. Сейчас же она предстает в роли скорее добротной, но отнюдь не новаторской работы. Глубина и масштаб теоретических обобщений вряд ли способен впечатлить исследователей, а богатство эмпирики - обывателей. Так что революция не состоялась, но в полку хороших книг прибыло. Не более того. Но и не менее. 


\section{Исследовательские проекты}

$\boldsymbol{V} \boldsymbol{R}$ Мы знакомим вас с двумя родственными проектами создания новых виртуальных центров в области социологии. Разработка обоих проектов была начата двумя исследовательскими командами параллельно (не сговариваясь) по сходной идеологии. Речь идет о создании ресурсных центров, которые будут не просто пассивными хранилищами информации и текстов, но намерены активно производить профессиональные ресурсы. Первый - проект создания ЭКСОЦЕНТРа (Центра экономической социологии). Второй - проект создания виртуального центра «Социология - Методы». Сайты обоих центров будут открыты для пользователей уже в 2002 г.

\section{Создание виртуального Центра экономической социологии ЭКСОЦЕНТР}

Руководитель проекта - Радаев Вадим Валерьевич.

Исследовательский коллектив - сотрудники Государственного университета - Высшей школы экономики и Московской Высшей школы социальных и экономических наук М. Лукьянчук, И. Назарова, Е. Новикова, И. Попова.

Постановка проблемы. В настоящее время нарастает фрагментация социальных наук, обусловленная их методологическим плюрализмом. В конечном счете останутся «на плаву» именно те направления, которые лучше консолидированы и институционализированы. Интенсивно развивающаяся с середины 1980-х гг. в России и в мире экономическая социология - один из наиболее вероятных претендентов на выживание. Важным инструментом ее консолидации и должен послужить создаваемый специализированный виртуальный центр экономической социологии, концентрирующий научные и образовательные ресурсы.

Число ресурсных центров сегодня постоянно возрастает. Однако их основной недостаток заключается в том, что они организуются как пассивные хранилища ресурсов, которые удалось заполучить в электронной форме. По степени релевантности и качества эти ресурсы зачастую весьма неоднородны. Нередко сайты омертвляются вскоре после открытия. Кроме этого, создатели ресурсных центров, как правило, пытаются охватить большое количество предметных областей, что приводит к сложной организации и размытости. Нужны иные формы работы, позволяющие концентрироваться на отдельных профессиональных направлениях и преодолевать очевидный дефицит качественных ресурсов.

Основные понятия. Экономическая сощиология - дисциплина, изучающая экономическое действие как форму социального действия. Виртуальный центр - организованная деятельность по производству и распространению профессиональных ресурсов посредством специального сайта.

Объект деятельности. На содержательном уровне объектом выступают профессиональные ресурсы, релевантные для экономической социологии (виды ресурсов см. в разделе «Структура сайта»). На техническом уровне объект деятельности - создание, поддержание и развитие специального сайта. 
Цель деятельности. Развитие ЭКСОЦЕНТРа - важный элемент политики фронтального продвижения экономической социологии как исследовательского направления в России и в мире. Конечная цель - консолидация российского исследовательского и образовательного сообщества в области экономической социологии и смежных дисциплин.

\section{Задачи ЭКСОЦЕНТРа:}

1. Обеспечение систематизированного и качественного доступа к профессиональным ресурсам.

2. Предложение новых способов упорядочивания и обработки ресурсов.

3. Непрерывное пополнение корпуса ссылок, текстов и данных в Рунете.

4. Производство новых профессиональных ресурсов.

5. Разработка одной из модельных форм работы с информацией, которая может (с коррективами) распространяться на другие специальные области в социальных и экономических науках.

Формы работы и методы сбора ресурсов. В отличие от обычных сайтов или порталов, ЭКСОЦЕНТР не является простым хранилищем ресурсов. Формы работы с ресурсами включают наряду с традиционным поиском и вывешиванием ресурсов:

- направленный отбор ресурсов по их качеству и соответствию стандартам;

- обработку ресурсов с приведением к стандартным формам;

- систематизацию ресурсов с помощью оригинальных предметных каталогов;

- производство ресурсов (аналитических обзоров, переводов, рецензий).

Методы сбора ресурсов включают:

- «пассивный» поиск в литературе и в Интернете;

- «активный» сбор информации посредством электронных опросов (три опроса российских специалистов уже проведены).

Основные литературные источники. Для каталогизации ресурсов используются (помимо прочих источников):

Радаев В.В. Экономическая социология: курс лекций. М.: Аспект Пресс, 1997 (1998, 2000).

Радаев В.В. Экономическая социология: современное состояние и перспективы развития / Ядов В.А. (отв. ред.) Социология в России. 2-е изд. дополн. М.: Институт социологии PAH, 1998. C. 253-263.

Экономическая социология: Новые подходы к институциональному и сетевому анализу / Под ред. В.В.Радаева. М.: РОССПЭН, 2002 (в печати).

\section{Структура сайта:}

- Новости + Новое на сайте

- Авторские и предметные каталоги

- Российские и зарубежные журнальные статьи (аннотации, ссылки) 
- Российские и зарубежные книги (титулы, оглавления, аннотации, рецензии, ссылки)

- Российские и зарубежные Интернет-ресурсы - электронные библиотеки, периодические издания, базы данных (ссылки, характеристики, обзоры)

- Экономическая социология в России и в мире (аналитические обзоры, научные центры, исследовательские проекты, исследователи, диссертации, конференции, фонды)

- Учебные программы, тексты, задания

- Тематические дискуссии.

\section{Имеющиеся заделы:}

- реализация проекта электронного журнала «Экономическая социология» (с осени 2000 г. вышли восемь номеров);

- проведение трех электронных опросов российских специалистов (опросная сеть превысила 200 респондентов);

- создание технической оболочки сайта ЭКСОЦЕНТРа;

- сбор минимально необходимого объема информации по всем рубрикам.

Проект реализуется про поддержке Фонда Форда и Государственного университета Высшей школы экономики. 


\section{Создание виртуального центра «Социология - Методы»}

Руководитель - д.с.н. Толстова Юлия Николаевна.

Исследовательский коллектив. Проект осуществляется при активном участии преподавателей, аспирантов и студентов ведущих вузов г. Москвы (МГУ, ГУ-ВШЭ, ГАУ и др.), специалистов в области методики и техники социологических исследований, СК «Город» ГУ-ВШЭ, а также Некоммерческого Партнерства «Человек и Информационное Общество».

Обоснование проекта. На сегодняшний день в области методики и техники социологических исследований существует ряд проблем:

1. Многие из перспективных методов сбора и анализа социологической информации остаются неразработанными в отечественной литературе. Например, незаслуженно забытым методом анализа данных являются лог-линейные модели (log-linear models), активно используемые зарубежными исследователями.

2. Развитие электронно-вычислительной техники и программного обеспечения сделало использование методов анализа данных доступным для широкого круга исследователей. Реализация в большинстве статистических пакетов (например, SPSS) принципа «нажал кнопку - получил результат» стимулирует необдуманное использование достаточно сложных методов в практике социологических исследований. Это привело к снижению уровня культуры использования математико-статистических методов в социологии.

3. Для адекватного использования методов анализа данных необходимо создание рабочих групп, включающих в себя специалистов как в различных областях социологии, так и в области методов сбора и анализа социологической информации, математики, статистики и пр.

4. Практически полное отсутствие специализированной учебной литературы на русском языке, доступной студентам и аспирантам, необходимой для подготовки специалистов в области методики и техники социологических исследований.

Создание виртуального центра «Социология - Методы» (далее - Центр) направлено на решение этих проблем.

Цель проекта - сформировать группу специалистов, способных:

- освоить существующие методы сбора и анализа социологических данных;

- модифицировать существующие методы сбора и анализа социологических данных под конкретные исследовательские задачи;

- Разработать и внедрить новые методы сбора и анализа социологических данных.

\section{Задачи проекта:}

1. Создать интернет-сайт, являющийся информационно-технической базой для обеспечения следующих направлений деятельности:

- $\quad$ создание информационной базы данных (БД), содержащей тексты, учебные материалы, материалы семинаров и конференций и прочие материалы по методам сбора и анализа социологической информации; 
- создание системы отбора и включения материалов в БД;

- создание поисковой системы, обеспечивающей быстрый доступ к необходимым материалам БД участников проекта;

- обеспечение коммуникацию между участниками проекта.

2. Выявить перспективные направления в области методов сбора и анализа социологической информации.

3. Привлечь к процессу работы по выявленным направлениям специалистов в различных областях социологии, методах сбора и анализа социологической информации, математики, статистики и пр., а также студентов и аспирантов.

\section{Целевая аудитория сайта}

1. Студенты и аспиранты, обучающиеся по направлению «Социология» и специализации «Методика и техника социологических исследований».

2. Преподаватели вузов, читающих курсы по методике и технике социологических исследований.

3. Специалисты в области методики и техники социологических исследований.

\section{Структура сайта}

\section{1. Новости сайта}

2. Персоналии - информация о ведущих специалистах.

3. Книжная полка - литература (книги, журналы, библиография).

4. Программное обеспечение - обзоры существующих статистических пакетов (SPSS, SAS, S-Plus, STATA и др.), их возможности и недостатки.

5. Словарь терминов - энциклопедический русско-английский словарь специальных терминов.

6. Подготовка специалистов - учебники, учебные пособия и другие учебные материалы. Обсуждение вопросов подготовки специалистов по методике и технике социологических исследований.

7. Консультации - справочная система, позволяющая выбрать стратегию (или возможные стратегии) анализа данных. Обсуждение вопросов, связанных с выбором методов анализа социологической информации.

8. Поддержка спещииалистов - информация о грантах, проектах и пр.

9. Лаборатория - методические разработки в области методов сбора и анализа социологической информации. Материалы работ в этом направлении и их обсуждение.

10. Форум - обсуждение проблем, статей, книг, учебных программ и т.п.

11. Ресурсы Интернет - ссылки на полезные интернет-ресурсы.

12. О проекте - информация о проекте, участниках, партнерах.

13. Поиск по сайту - поиск по ключевому слову. 


\section{Реализация проекта}

Первый этап заключается в подготовке информационно-технической базы для дальнейшего функционирования Центра:

1. Создание сайта и его регистрация.

2. Открытие рубрик:

- Книжная полка

- Словарь терминов

- Подготовка специалистов

- Поддержка специалистов

- Ресурсы Интернет

3. Обеспечение открытого доступа к ресурсам Центра.

Второй этап предполагает:

1. Пополнение рубрик.

2. Добавление рубрик:

- Персоналии

- Программное обеспечение

- Консультации

- Форум

3. Корректировка структуры сайта.

4. Продвижение сайта.

5. Привлечение специалистов в области методики и техники социологических исследований.

6. Выявление перспективных направлений работы в области методики и техники социологических исследований.

Третий этап предполагает:

- дальнейшее пополнение и расширение рубрик сайта;

- проведение собственных методических разработок;

- организацию курсов дистанционного обучения;

- проведение семинаров, консультаций, курсов;

- организация конференций;

- выпуск публикаций.

В настоящий момент ведутся переговоры с редакцией журнала «Социология: 4М» о предоставлении материалов для их размещения на сайте.

Подготовлено участником проекта А.В.Ермолаевым. 


\section{Учебные программы}

$\boldsymbol{V} \boldsymbol{R}$ «Современная экономическая социология» - совершенно новая программа, выходящая далеко за рамки книги: Радаев В.В. Экономическая социология: курс лекций. (М.: Аспект Пресс, 1997). Ее основная часть посвящена новым и новейшим направлениям западной экономической социологии. Лекционный курс по этой программе впервые был прочитан осенью 2001 г. на факультете социологии ГУ-ВШЭ.

\section{СОВРЕМЕННАЯ ЭКОНОМИЧЕСКАЯ СОЦИОЛОГИЯ \\ Радаев Вадим Валерьевич}

Читается в ГУ-ВШЭ, бакалавриат, четвертый курс.

Продолжительность - 18 недель (осенний полусеместр).

Отчетность - контрольная и письменный экзамен.

\section{Базовая учебная литература:}

Радаев В.В. Экономическая социология: курс лекций. М.: Аспект Пресс, 1997 (репринты 1998, 2000).

Радаев В.В. - серия статей в журнале «Вопросы экономики» (1994, № 7; 1995, № 2; 1996, №№ $1,7,10,12 ; 1998$, № 10; 2000, № 2; 2001, № 6).

Радаев В.В. - серия статей в журнале «Социологические исследования» (1991, № 1; 1997, № 4; 1999, № 3; 2000, № 8).

\section{Тема 1. Особенности экономико-социологического подхода}

Экономическая социология как исследовательский подход. Границы между экономическим и экономико-социологическим подходами. Модели экономического и социологического человека. Принципы построения модели экономико-социологического человека. Структура хозяйственной мотивации. Принципы действия и стратегии действия.

Основная литература:

Бруннер $K$. Представление о человеке и концепция социума: два подхода к пониманию общества // THESIS 1993. Т. 1. Вып. 3. С. 51-72.

Вайзе П. Homo economicus и homo sociologicus: монстры социальных наук // THESIS, 1993. Т. 1. Вып. 3. С. 115-130.

Радаев В.В. Экономическая социология: курс лекций. М.: Аспект Пресс, 1997. Глава 3. С. 50-58; Глава 4; С. 64-71, Глава 5, С. 94-95. 
Дополнительная литература:

Автономов B.C. Модель человека в экономической науке. СПб.: Экономическая школа, 1998.

Веселов Ю.В. Экономическая социология: история идей. СПб.: Изд-во С.-Петербургского ун-та, 1995.

Paдаев B.B. К обоснованию модели поведения человека в социологии (основы «экономического империализма») / Социологические чтения. Вып. 2. М.: Институт социологии РАН, 1997. С. 177-189.

Granovetter, M., and R. Swedberg (eds.), The Sociology of Economic Life. Boulder: Westview Press, 1992. Introduction. P. 1-19.

Smelser, N., and R.Swedberg. The Sociological Perspective on the Economy, in: Smelser, N., and R. Swedberg, R. (eds.) The Handbook of Economic Sociology. Princeton: Princeton University Press, 1994. P. 3-26.

\section{Тема 2. Социальные основы экономического действия (М.Вебер)}

Понятие социального действия. Экономическое действие как форма социального действия. Понятие рациональности. Формальная и содержательная рациональность. Понятие хозяйственной организации. Бюрократическая организация. Понятие денег и денежный обмен. Понятие хозяйственного духа. Социальные основы развития капиталистического хозяйства.

Основная литература:

Вебер М. Основные социологические понятия / Вебер М. Избранные произведения. М.: Прогресс, 1990. С. 625-636.

Радаев В.В. Экономическая социология: курс лекций. Глава 2, С. 37-42; Глава 3, С. 53-55; Глава 4, С. 71-79; Глава 6, С. 102-106; Глава 8, С. 136-139.

Weber, M. Economy and Society. Berkeley: University of California Press, 1978. Vol. I. P. 6385.

Дополнительная литература:

Вебер М. Основные понятия стратификации // Социологические исследования, 1994. № 5. C. 147-156.

Вебер М. Протестантская этика и дух капитализма / Избранные произведения. М.: Прогресс, 1990. С. 61-106, 136-207.

Вебер М. История хозяйства. Город. М.: Канон-Пресс-Ц, Кучково поле, 2001. С. 5-332.

Зомбарт В. Буржуа. М.: Наука, 1994. С. 45-49, 82-103.

Радаев B.B. Хозяйственная мотивация и типы рациональности // Социологический журнал, 1997. № 1-2. С. 183-200.

Collins, R. Weber's Last Theory of Capitalism, in: Granovetter, M., and R. Swedberg (eds.) The Sociology of Economic Life. P. 85-110. 
Holton, R. and Turner, B. Max Weber on Economy and Society. L.: Routledge. 1989.

Parkin, F. Max Weber. L.: Routledge, 1993. P. 90-108.

Swedberg, R. Max Weber and the Idea of Economic Sociology. Princeton: Princeton University Press, 1998.

Weber, Max. Essays in Economic Sociology / Ed. by R.Swedberg. Princeton: Princeton Uunversity Press, 1997.

\section{Тема 3. Два значения «экономического» (К.Поланьи)}

Антропологический подход в экономической социологии. Формальное и содержательное значения термина «экономический». Хозяйство как институционально оформленный процесс. Историческая ограниченность рыночной формы хозяйства. Формы интеграции: реципрокность, перераспределение и обмен. Формы торговли, функции денег и элементы рынка. Труд, земля и деньги как фиктивные товары.

Основная литература:

Полани К. Два значения термина «экономический». О вере в экономический детерминизм // Неформальная экономика: Россия и мир / Под ред. Т.Шанина. М.: Логос, 1999. С. 505513.

Радаев В.В. Экономическая социология: курс лекций. Глава 2. С. 42-44.

Дополнительная литература:

Поланьи K. Саморегулирующийся рынок и фиктивные товары: труд земля и деньги // THESIS, 1993. Т. 1. Вып. 2. С. 10-17.

Якубович В. Институты, социальные сети и рыночный обмен: Подбор работников и рабочих мест в России / Радаев В.В. (ред.) Экономическая социология: Новые подходы к институциональному и сетевому анализу. М.: РОССПЭН, 2001 (в печати).

Block, F. Postindustrial Possibilities. Berkeley: University of California Press, 1990. Chapter 2. P. 21-45.

Mingione, E. Fragmented Societies: A Sociology of Economic Life Beyond the Market Paradigm. Oxford: Basil Blackwell, 1991.

Polanyi, K. The Great Transformation. N.Y.: Farrar and Rinehart, 1944.

Polanyi, K. Primitive, Archaic and Modern Economies: Essays of Karl Polanyi. Boston: Beacon Press, 1971.

Polanyi K. The Livelihood of Man /Ed. by H.W.Pearson. N.Y.: Academic Press, 1977. P. 19-34.

Polanyi, K. The Economy as Instituted Process, in: Granovetter, M., and R. Swedberg (eds.) The Sociology of Economic Life. Boulder: Westview Press, 1992. P. 29-52.

Polanyi, K., Arenberg, C.M., and H.W.Pearson (eds.) Trade and Market in Early Empires. Glencoe: The Free Press, 1957. 


\section{Тема 4. Новые направления в экономической социологии (Р.Сведберг)}

Реконструкция экономико-социологической традиции. Исторические этапы ее становления. «Старая» экономическая социология. Экономический империализм и новая экономическая социология. Институционализация экономической социологии в 1980-90-е годы. Новейшие подходы в экономической социологии. Американская и европейские ветви экономической социологии. Развитие смежных дисциплин.

Основная литература:

Радаев В.В. Экономическая социология: курс лекций. М.: Аспект Пресс, 1997. Глава 2. C. 45-49.

Swedberg, R. New Economic Sociology: What Has Been Accomplished, What Is Ahead?, Acta Sociologica (1997). Vol. 40. P. 161-182.

Дополнительная литература:

Радаев В.В. Основные направления развития современной экономической социологии / Радаев В.В. (ред.) Экономическая социология: Новые подходы к институциональному и сетевому анализу. М.: РОССПЭН, 2001 (в печати).

Callon, M. (ed.) The Law of Markets. Oxford: Blackwell, 1998. Introduction. P. 1-57.

Carruthers, B. G. and S.L. Babb, Economy / Sociology: Markets, Meanings, and Social Structures. Thousands Oaks, CA: Pine Forge Press, 2000.

Granovetter, M., and R. Swedberg (eds.) The Sociology of Economic Life. Boulder: Westview Press, 1992. Introduction. P. 1-19.

Guillen, V.F., Collins, R., England, P., and V. Meyer (eds.) Economic Sociology at the Millennium, N.Y.: Russel Sage Foundation, 2001.

Holton, R. Economy and Society. L.: Routledge, 1992.

Lin, N. Social Capital: A Theory of Social Structure an Action. N.Y.: Cambridge University Press, 2000.

Smelser, N., and R. Swedberg. The Sociological Perspective on the Economy, in: Smelser, N., and R. Swedberg (eds.) The Handbook of Economic Sociology. P. 3-26.

\section{Тема 5. Социология рационального выбора (Дж.Коулмен)}

Понятие рационального выбора в экономической теории и социологии. Объединение предпосылок экономической и социологической теорий. Влияние социальной структуры на социальное действие. Понятие социального капитала. Корпоративные акторы и эволюция организационных форм. Переход от микроуровня на макроуровень. Теории социального выбора. Рациональность, социальные нормы и принуждение.

Основная литература:

Радаев B.B. Экономическая социология: курс лекций. М.: Аспект Пресс, 1997. Глава 2, С. 45-46; Глава 4, С. 68-75.

Coleman, J. A Rational Choice Perspective on Economic Sociology, in: Smelser, N., and R. Swedberg (eds.). The Handbook of Economic Sociology. P. 166-180. 
Дополнительная литература:

Беккер Г. Экономический анализ и человеческое поведение // THESIS, 1993. Т. 1. Вып. 1. C. 24-40.

Олсон М. Логика коллективных действий: общественные блага и теория групп. М.: Фонд экономической инициативы, 1995.

Эльстер Ю. Социальные нормы и экономическая теория // THESIS, 1993. Т. 1. Вып. 3. С. 73-91.

Радаев B. О рациональности и коллективном действии (О книге М.Олсона «Логика коллективного действия») // Вопросы экономики, 1996. № 10, С. 144-152.

Швери P. Теоретическая концепция Джеймса Коулмена: аналитический обзор // Социологический журнал, 1996. № 1-2. С. 62-81.

Coleman, J. Introducing Social Structure into Economic Analysis, American Economic Review. Papers and Proceedings (May 1984). Vol. 74, No. 2. P. 85-88.

Coleman, J. Social Theory, Social Researh and the Theory of Action, American Journal of Sociology (1986). No. 91. P. 1309-1335.

Coleman, J. Interview / Swedberg, R. (ed.) Economics and Sociology: Redefining Their Boundaries. Princeton: Princeton University Press, 1990. P. 47-60.

Coleman J. Foundations of Social Theory. Belknap: Harvard University Press, 1990. Chapter 16. P. 421-450.

Elster J. Nuts and Bolts for the Social Sciences. Cambridge: Cambridge University Press, 1989.

\section{Тема 6. Новая экономическая социология (М.Грановеттер)}

Недосоциализированная и пересоциализированная концепции человеческого действия. Концепция укорененности (встроенности) экономического действия. Социальное конструирование экономических институтов. Доверие и оппортунизм. Социология производственных рынков. Использование сетей на внутренних и внешних рынках труда.

\section{Основная литература:}

Радаев В.В. Экономическая социология: курс лекций. М.: Аспект Пресс, 1997. Глава 2 , С. 46-47; Глава 3, С. 53-55.

Granovetter, M. Economic Insitutions as Social Constructions: A Framework for Analysis, Acta Sociologica (1992). Vol. 35. P. 3-11.

Дополнительная литература:

Уайm X. Рынки и фирмы: взаимообусловленное возникновение / Радаев В.В. (ред.) Экономическая социология: Новые подходы к институциональному и сетевому анализу. М.: РОССПЭН, 2001 (в печати) или (английский вариант): Экономическая социология, 2001. Т. 2, № 4. http://www.ecsoc.msses.ru.

Granovetter, M. Interview / Swedberg, R. (ed.). Economics and Sociology: Redefining Their Boundaries. Princeton: Princeton University Press, 1990. P. 96-114. 
Granovetter, M. Economic Action and Social Structure: The Problem of Embeddedness, in: Granovetter, M., and R. Swedberg (eds.) The Sociology of Economic Life. P. 53-81.

Granovetter, M. The Sociological Approaches to Labor Market Analysis: A Social Structural View, in: Granovetter, M., and R. Swedberg (eds.) The Sociology of Economic Life. P. 233-263.

Granovetter, M. Business Groups, in: Smelser, N., and R. Swedberg (eds.) The Handbook of Economic Sociology. P. 453-475.

Granovetter, M. The Economic Sociology of Firms and Entrepreneurs, in: Portes, A. (ed.) The Economic Sociology of Immigration: Essays on Networks, Ethnicity, and Entrepreneurship. N.Y.: Russell, 1995. P. 128-165.

Swedberg, R. New Economic Sociology: What Has Been Accomplished, What Is Ahead?, Acta Sociologica (1997). Vol. 40. P. 161-182.

White, H. Where Do Markets Come From?, American Journal of Sociology (1981). Vol. 87. P. 517-547.

\section{Тема 7. Экономическая теория конвенций (Л.Тевено)}

Понятие сложности (комплексности) хозяйственных явлений. Установление эквивалентности и возможность конвенций. Общие миры как исторические конструкции. Конфликт между формами координации. Порядки обоснования ценности и отношения между ними. Хозяйственная организация как компромиссное средство координации.

Основная литература:

Тевено Л. Множественность способов координации: равновесие и рациональность в сложном мире // Вопросы экономики, 1997. № 10. С. 69-84.

Тевено Л. Рациональность или социальные нормы: преодоленное противоречие? / Право и экономика: традиционный взгляд и перспективы развития. М.: ГУ-ВШЭ, 1999. С. 159-208 или // Экономическая социология, 2001. Том 2. № 1. С. 88-122. http://www.ecsoc.msses.ru.

Дополнительная литература:

Болтански Л., Тевено Л. Социология критической способности // Журнал социологии и социальной антропологии, 2000. Т. 3, № 3. С. 66-83.

Олейник $A$. В поисках институциональной теории переходного общества // Вопросы экономики, 1997. № 10. С. 58-68.

Олейник А.Н. Институциональная экономика: Учебное пособие. М.: ИНФРА-М, 2000. Лекция 2. С. 25-33.

Тевено Л. Какой дорогой идти? Моральная сложность «обустроенного» человечества // Журнал социологии и социальной антропологии, 2000. Т. 3, № 3. С. 84-111.

Тевено Л. Организованная комплексность: нормы координации и структура экономических преобразований / Радаев В.В. Экономическая социология: Новые подходы к институциональному и сетевому анализу. М.: РОССПЭН, 2001 (в печати). 
Фавро О. К экономической теории норм / Право и экономика: традиционный взгляд и перспективы развития. М.: ГУ-ВШЭ, 1999. С. 147-158.

Boltanski, L. Visions of American Management in Postwar France, in: Zukin, S., and P. DiMaggio (eds.). Structure of Capital: The Social Organization of the Economy. N.Y.: Cambridge University Press, 1994. P. 343-372.

\section{Тема 8. Сетевой подход и хозяйственные организации (Д.Старк)}

Понятие сетевых отношений. Функции сетей. Основные характеристики сетей. Сильные и слабые связи. Понятие структурной эквивалентности. Формальные и неформальные сетевые связи. Внутрифирменная сеть как способ гибкой организации. Понятие гетерархии. Бизнес-группы и деловые сети как промежуточные звенья между рынком и вертикальной интеграцией. Рекомбинированная собственность. Сети как способ манипулирования ресурсами в российском хозяйстве.

Основная литература:

Старк Д. Рекомбинированная собственность и рождение восточноевропейского капитализма // Вопросы экономики, 1996. № 6. С. 4-24.

Powell, W., and L. Smith-Doerr. Networks and Economic Life, in: Smelser, N., and R. Swedberg (eds.) The Handbook of Economic Sociology. P. 368-402.

Дополнительная литература:

Радаев В.В. Сетевой мир // Эксперт, 2000. 27 марта (№ 12). С. 34-37.

Паппе Я.Ш. Олигархи. Экономическая хроника. 1992-2000. М.: ГУ-ВШЭ, 2000.

Baker, W.E. The Social Structure of a National Securities Market, American Journal of Sociology (1984). Vol. 89, No. 4. P. 775-811.

Baker, W. Networking Smart. N.Y.: McGraw Hill, 1994.

Biggart, N. Charismatic Capitalism: Direct Selling Organizations in America. Chicago: University of Chicago Press, 1998 (1989).

Burt, R.S. Structural Holes: The Social Structure of Competition. Cambridge: Harvard University Press, 1995.

Carruthers, B. G. and S.L. Babb, Economy / Sociology: Markets, Meanings, and Social Structures. Thousands Oaks, CA: Pine Forge Press, 2000. Chapter 3. P. 45-70.

Perrow, C. Small Firm Networks, in: Swedberg R. (ed.) Explorations in Economic Sociology. N.Y.: Russel Sage Foundation, 1993. P. 377-402.

Stark, D. Ambiguous Assets for Uncertain Environment: Heterarchy in Postsocialist Firms, Экономическая социология (2000). Т. 1, № 2. С. 7-36; фрагмент перевода: Т. 2, № 2, C. 115-132. http://www.ecsoc.msses.ru.

Wasserman, S., and J. Galaskievicz (eds.). Advances in Social Network Analysis. L.: Sage, 1994.

White, H.C. Varieties of Markets, in: Wellman, B., and S.D. Berkowitz (eds.) Social Structures: A Network Approach. N.Y.: Cambridge University Press, 1988. P. 226-260. 


\section{Тема 9. Новый институционализм и социология рынков (Н.Флигстин)}

Понятие хозяйственных институтов. Старый и новый институционализм. Связь с новой институциональной экономикой. Институциональные образования: права собственности, структуры управления и правила обмена. Мотивационная структура хозяйственных агентов. Концепции контроля и способы легитимации действий. Эффективность институтов. Проблемы измерения трансакционных издержек.

\section{Основная литература:}

Радаев В.В. Новый институциональный подход: построение исследовательской схемы // Журнал социологии и социальной антропологии, 2001 (в печати) или Экономическая социология, 2001. Т. 2, № 3. C. 5-26. http://www.ecsoc.msses.ru.

Fligstein, N. Markets as Politics: A Political-Cultural Approach to Market Institutions, American Sociological Review (August 1996). Vol. 61. P. 656-673.

Дополнительная литература:

Норт Д. Институты, институциональные изменения и функционирование экономики. М.: Начала, 1997.

Олейник А.Н. Институциональная экономика: Учебное пособие. М.: ИНФРА-М, 2000. Лекция 3, С. 43-52.

Радаев B.B. Формирование новых российских рынков: трансакционные издержки, формы контроля и деловая этика. М.: Центр политических технологий, 1998. Введение. C. 9-25.

Радаев B.B. Некоторые институциональные условия формирования российских рынков // Социологический журнал, 1998. № 3-4. С. 57-85.

Радаев В.B. Рынок как объект социологического исследования // Социологические исследования, 1999. № 3. С. 28-37.

Радаев В.В. Новый институциональный подход и деформализация правил в российской экономике / Радаев В.В. (ред.). Экономическая социология: Новые подходы к институциональному и сетевому анализу. М.: РОССПЭН, 2001 (в печати).

Шаститко А.Е. Неоинституциональная экономическая теория. М.: ТЕИС, 1998.

Baker, W., Faulkner, R., and Fisher, G. Hazards of the Market: The Continuity and Dissolution of Interorganizational market Relationships, American Sociological Review (April 1998). Vol. 63. P. 147-177.

Brinton, M. and V. Nee (eds.) The New Institutionalism in Sociology. N.Y.: Russell Sage Foundation, 1998. P. 1-45.

Fligstein, N. The Transformation of Corporate Control. Cambridge: Harvard University Press, 1990.

Fligstein, N. Fields, Power, and Social Skill: A Critical Analysis of The New Institutionalisms // Экономическая сочиология, 2001. Т. 2, № 1. С. 4-25 или (перевод): Т. 2, № 4, 2001. http://www.ecsoc.msses.ru.

Powell, W., and P. DiMaggio (eds.) The New Institutionalism in Organizational Analysis. Chicago, IL: University of Chicago Press, 1991. 


\section{Тема 10. Властный подход. Государство и экономика (Ф.Блок)}

Понятие хозяйственной власти. Власть и собственность. Роль государства в формировании рынков. Типы государственного вмешательства. Либеральные и марксистские трактовки государства. Государство как агент хозяйственной деятельности. Специфика торга на бюрократических рынках. Коммерциализация государства и проблема коррупции в современной России.

Основная литература:

Радаев В.В. Экономическая социология: курс лекций. М.: Аспект Пресс, 1997. Глава 5, C. 80-84.

Block, F. The Role of the State in the Economy, in: Smelser, N., and R. Swedberg (eds.). The Handbook of Economic Sociology. Princeton: Princeton University Press, 1994. P. 691710 .

Дополнительная литература:

Радаев B.B. Формирование новых российских рынков: трансакционные издержки, формы контроля и деловая этика. М. Центр политических технологий, 1998. Глава 1, С. 28 81 или Радаев B.B. Коррупция и формирование российских рынков: отношения чиновников и предпринимателей // Мир России, 1998. № 3. С. 57-90.

Радаев B.B. Государство и предприниматель: отношения на микроуровне // Вопросы статистики, 1998. № 12. С. 3-8.

Радаев В.В., Шкаратан О.И. Власть и собственность // Социологические исследования, 1991. № 1. С. 50-61.

Block, F. Postindustrial Possibilities. Berkeley: University of California Press, 1990.

Esping-Andersen, G. The Three Worlds of Welfare Capitalism. Cambridge: Polity Press, 1990. P. 9-34.

Evans, P. B. Embedded Autonomy. Berkeley: University of California Press, 1995.

Evans, P., and J. Rauch. Bureaucracy and Growth: A Cross-National Analysis of the Effects of "Weberian" State Structures on Economic Growth, American Sociological Review (October 1999). Vol. 64. P. 748-765.

Frye, T., and A. Shleifer. The Invisible Hand and the Grabbing Hand, American Economic Review. Papers and Proceedings. Vol. 87, No. 2. P. 354-358.

Shleifer, A., and R.Vishny, R. The Grabbing Hand: Government Pathologies and Their Cures. Cambridge: Harvard University Press, 1998.

Weber M. Economy and Society. Berkeley: University of California Press, 1978. Vol. I. P. 53-56.

\section{Тема 11. Сравнительный анализ хозяйственных организаций (Н.Биггарт)}

Основные теории экономического развития. Различие институционального оформления рынков и многообразие организационных логик. Сравнительный анализ трудовых отношений. Экономическая организация как фактор национальной конкурентоспособности. Специфика российских форм хозяйственной организации. 
Основная литература:

Радаев В.В. Экономическая социология: курс лекций. М.: Аспект Пресс, 1997. Глава 8, С. 139-141; Глава 10, С. 165-168.

Biggart, N., and M. Guillen. Developing Defference: Social Organization and the Rise of the Auto Industries of South Korea, Taiwan, Spain, and Argentina, American Sociological Review (October 1999). Vol. 64. P. 722-747.

Дополнительная литература:

Биггарт H. Социальная организация и экономическое развитие / Радаев В.В. (ред.). Экономическая социология: Новые подходы к институциональному и сетевому анализу. М.: РОССПЭН, 2001 (в печати) или Экономическая социология, 2000. Т. 1, № 1. http://www.ecsoc.msses.ru.

Dore, R. British Factory - Japanese Factory: the Origins of National Diversity in Industrial Relations. L.: George Allen and Unwin, 1973.

Dore, R. Stock Market Capitalism: Welfare Capitalism. Japan and Germany Versus the AngloSaxons. Oxford: Oxford University Press, 2000.

Gereffi, G. The International Economy and Economic Development, in: Smelser, N., and R. Swedberg (eds.) The Handbook of Economic Sociology. Princeton: Princeton University Press, 1994. P. 206-232.

Lincoln, J.R., and A.L. Kalleberg. Culture, Control and Commitment: A Study of Work Organization and Work Attitudes in the United States and Japan. Cambridge: Penguin Books, 1978.

Orru, M., Biggart, N., and G. Hamilton. The Economic Organization of East Asian Capitalism. L.: Sage, 1997.

Porter, M. The Competitive Advantage of Nations. N.Y.: Free Press, 1990.

\section{Тема 12. Субстантивистский подход. Неформальная экономика (А.Портес)}

Понятие неформальной и теневой экономики. Классификация сегментов неформальной экономики. Способы измерения теневой экономики. Неформальная экономика домашних хозяйств. Теневая экономика предприятий. Способы связи формальных и неформальных правил. Деформализация хозяйственных правил. Издержки легализации и уход от налогов. Качественные изменения в теневой экономике в постсоветский период.

Основная литература:

Радаев В.В. Теневая экономика в России: изменение контуров // Pro et Contra (зима 1999). T. 4, № 1. C. 5-24.

Portes, A. The Informal Economy and Its Paradoxes, in: Smelser, N., and R. Swedberg (eds.) The Handbook of Economic Sociology. Princeton: Princeton University Press, 1994. P. 426-449. 
Дополнительная литература:

Леденева A. Теневой бартер: повседневность малого бизнеса / Шанин Т. (ред.) Неформальная экономика: Россия и мир. М.: Логос, 1999. С. 292-310.

Неформальный сектор в российской экономике / Научн. ред. Т.Г. Долгопятова. М.: ИСАРП, 1998.

Радаев B.B. Формирование новых российских рынков: трансакционные издержки, формы контроля и деловая этика. М. Центр политических технологий, 1998.

Радаев B.B. Деформализация правил и уход от налогов в российской хозяйственной деятельности // Вопросы экономики, 2001. № 6. С. 60-79.

Яковлев А. Экономика «черного нала» в России: механизмы, причины, последствия / Шанин Т. (ред.) Неформальная экономика. С. 270-291.

Feige, E.L. Defining and Estimating Underground and Informal Economies: The New Institutional Economics Approach, World Development (1990). Vol. 18, No. 7. P. 9891002 .

Feige, E.L., and K. Ott (eds.) Underground Economies in Transition. Aldershot: Elgar, 1999.

Portes, A., and S. Sassen-Koob. Making It Underground: Comparative Material on the Informal Sector in Western Market Economies, American Journal of Sociology (July 1987). Vol. 93, No. 1. P. 51-56.

Portes A., Castells M., and L. Benton (eds.) The Informal Economy: Studies in Advanced and Less Developed Countries. Baltimore: John Hopkins University Press, 1989. Conclusion. P. 298-311.

Radaev, V. Urban Households in the Informal Economy, in: Segbers, K. (ed.) Explaining PostSoviet Patchworks. Vol. 2. Aldershot: Ashgate, 2001. P. 333-361.

\section{Тема 13. Политико-экономический подход. Социология домашнего хозяйства (Дж.Гершуни)}

Новая экономическая теория домашнего производства. Политическая экономия времени. Виды труда и время досуга. Исторические тенденции в использовании времени в домашнем хозяйстве. Развитие сферы услуг и ее влияние на домашний труд. Гендерные роли в домашнем хозяйстве. Принципы распределения труда между супругами в российском обществе.

Основная литература:

Барсукова С.Ю., Радаев В.В. Легенда о гендере. Принципы распределения труда между супругами в современной городской семье // Мир России, 2000. № 4. С. 65-102 или Экономическая социология, 2001. Т. 2, № 2. С. 23-60. http://www.ecsoc.msses.ru .

Гершуни Дж. Бюджеты времени и неформальная экономическая деятельность / Шанин Т. (ред.) Неформальная экономика: Россия и мир. М.: Логос, 1999. С. 343-355. 
Радаев В.В. Экономическая социология: курс лекций, Глава 14 или Радаев В.В. Домашнее хозяйство и неформальная экономика // Социологические исследования, 1997. № 4. C. 64-72.

Дополнительная литература:

Беккер Г. Экономика семьи и макроповедение // США: экономика, политика, идеология, 1994. № 1. С. 99-107; № 2. С. 93-98.

Гершуни Дж. Экономическая социология: либеральные рынки, социальная демократия и использование времени // Экономическая социология, 2000. Т. 1, №2. С. 72-81. http://www.ecsoc.msses.ru.

Поллак $P$. Трансакционный подход к изучению семьи и домашнего хозяйства // THESIS, 1994. № 6. C. 50-73.

Anderson, M., Bechhofer, F., and J. Gershuny (eds.) The Social and Political Economy of the Household. Oxford: Oxford University Press, 1994. Introduction. P. 1-16.

Gershuny, J. After Industrial Society. L.: Macmillan, 1978.

Gershuny, J. Time, Technology and the Informal Economy, in: Pahl, R.E. (ed.) On Work: Historical, Comparative and Theoretical Approaches, Oxford: Basil Blackwell, 1988. P. 579-597.

Gershuny, J. Changing Times: Work and Leisure in Postindustrial Society. Oxford: Oxford University Press, 2001.

Wheelock, J., and A.Mariussen (eds.) Households Work and Economic Change: A Comparative Institutional Perspective. Boston: Kluwer, 1997.

\section{Тема 14. Этнографический подход. Рынки как культуры (М.Аболафия)}

Понятие хозяйственной культуры. Культурная укорененность экономических отношений. Регулятивные функции культуры. Конституирующие правила и роли. Понятие локальной рациональности и множественность типов рациональности. Труд и социализация. Обмен и самоутверждение. Потребление и соучастие. Специфика этнографического подхода в изучении рынков.

Основная литература:

Радаев В.В. Экономическая социология: курс лекций. М.: Аспект Пресс, 1997. Глава 4, С. 77-79; Глава 5, С. 80-81, 84-89.

Abolafia, M. Markets as Cultures: An Ethnographic Approach. in: Callon, M. (ed.) The Law of Markets. Oxford: Blackwell, 1998. P. 69-85.

Дополнительная литература:

Abolafia, M. Making Markets, Opportunism and Restraints on Wall Street. Cambridge, Mass: Harvard University Press, 1996. 
Abolafia, M., and N. Biggart. Competition and Markets: An Institutional Perspective, in: Etzioni, A., and P.R. Lawrence (eds.). Socio-Economics: Toward a New Synthesis. Armonk. N.Y.: M.E.Sharpe, 1991. P. 211-232.

Carruthers, B. G. and S.L. Babb. Economy / Sociology: Markets, Meanings, and Social Structures. Thousands Oaks, CA: Pine Forge Press, 2000. Chapter 2. P. 15-44.

DiMaggio, P. Culture and Economy, in: Smelser, N., and R. Swedberg (eds.) The Handbook of Economic Sociology. P. 27-57.

Holton, R. Economy and Society. L.: Routledge, 1992. Chapters 7-9. P. 179-271.

\section{Тема 15. Культурно-исторический подход. Социология денег (В.Зелизер)}

Политическая экономия денег. Деньги как универсальный посредник. Деньги как социальное отношение. Множественность денег. Денежные суррогаты. Денежная культура населения. Социология финансового поведения населения. Массовое финансовое поведение и «финансовые пирамиды».

\section{Основная литература:}

Радаев В.В. Экономическая социология: курс лекций. М.: Аспект Пресс, 1997. Глава 5, C. 89-94.

Zelizer, V. Making Multiple Money, in: Swedberg, R. (ed.) Explorations in Economic Sociology. N.Y.: Russel Sage Foundation, 1993. P. 193-212.

Дополнительная литература:

Радаев B.B. О сбережениях и сберегательных мотивах российского населения // Вопросы социологии, 1998. Вып. 8. С. 39-54.

Радаев B.B. Возвращение толпы: анализ поведения вкладчиков «финансовых пирамид» // Вопросы социологии, 1998. Вып. 8. С. 100-142.

Dodd, N. The Sociology of Money: Economics, Reason and Contemporary Society. Cambridge: Polity Press, 1994.

Furnham, A., and M. Argyle. The Psychology of Money. L.: Routledge, 1998. Chapters 1-2.

Mizruchi, M., and L.B. Stearns. Money, Banking, and Financial Markets, in: Smelser, N., and R. Swedberg (eds.) The Handbook of Economic Sociology. P. 313-341.

Radaev, V. Return of the Crowds and Rationality of Action: A History of Russian 'Financial Bubbles' in the mid-1990s, European Societies (2000). Vol. 2, No. 3. P. 271-294.

Simmel, G. The Philosophy of Money. L.: Routledge and Kegan Paul, 1990. P. 429-446.

Weber, M. Economy and Society, Vol. I. P. 166-193.

Zelizer, V. Human Values and the Market: The Case of Life Insurance and Death in $19^{\text {th }}$-century America, American Journal of Sociology (1978). Vol. 84. P. 591-610.

Zelizer, V. Pricing the Priceless Child. The Changing Social Value of Children. N.Y.: Basic Books, 1985. 
Zelizer, V. The Social Meaning of Money. N.Y.: Basic Books, 1994.

Zelizer, V. The Prolifiration of Social Currencies, in: Callon, M. (ed.) The Law of Markets, Oxford: Blackwell, 1998. P. 58-68.

\section{Тема 16. Стратификационный подход (Дж.Голдторп)}

Специфика классового подхода. Исходные положения веберовской стратификационной теории. Полемика с неомарксизмом и функционализмом. Множественность оснований стратификационного деления. Класс, статусная группа и коллективное действие. Социальная мобильность в развитых западных странах. Неовеберианские эмпирические исследования.

Основная литература:

Радаев В.В., Шкаратан О.И. Социальная стратификация. М.: 1996. Глава 5, С. 121-139 (или М.: 1995. Глава 5, С. 94-109).

Goldthorpe, J., and G. Marshall. The Promising Future of Class Analysis, in: Marshall, G. Repositioning Class: Social Inequality in Industrial Societies. L.: Sage, 1997. P. 49-64 or in: Lee, D., and B. Turner (eds.). Conflicts about Class: Debating Inequality in Late Industrialism. L.: Longman, 1996. P. 98-109.

\section{Дополнительная литература:}

Радаев В.В. Экономическая социология: курс лекций. М.: Аспект Пресс, 1997. Глава 16 или Радаев В. Основные направления стратификационной теории // Российский экономический журнал, 1995. № 1, С. 64-66.

Радаев В.В. Стратификационный анализ постсоветской России: неовеберианский подход / Бутенко И.А. (отв. ред.). Способы адаптации населения к новой социальноэкономической ситуации в России. Выпуск XI, М.: Московский общественный научный фонд, 1999. С. 46-59.

Erikson, R., and J. Goldthorpe. The Constant Flux. Oxford: Clarendon Press, 1992. P. 1-27.

Giddens, A. The Class Structure of Advanced Societies, in: Grusky, D. (ed.) Social Stratification: Class, Race, and Gender in Sociological Perspective. Boulder: Westview Press, 1994. P. 131-140.

Goldthorpe, J.H. Social Mobility and Class Structure in Modern Britain. Oxford: Clarendon Press, 1980. Chapters 1-2, 9.

Goldthorpe, J. Intellectuals and the Working Class in Modern Britain, in: Rose, D. (ed.) Social Stratification and Economic Change. L.: Hutchinson, 1988. P. 39-56.

Goldhorpe, J. On Sociology: Numbers, Narratives, and the Integration of Research and Theory. Oxford: Oxford University Press, 2001. 
Parkin, F. Marxism and Class Theory: A Bourgeois Critique. L.: Tavistock Publications, 1979. P. 44-73 or Grusky, D. (ed.) Social Stratification: Class, Race, and Gender in Sociological Perspective. P. 141-154.

Runciman, W.G. How Many Classes Are There in Contemporary British Society?, Sociology (August 1990). Vol. 24, No. 3. P. 377-396.

\section{Тема 17. Постструктуралистский подход (П.Бурдье)}

Социальное пространство и силовые поля. Роль экономического поля. Обладание капиталами и власть над полем. Классы на бумаге и реальные классы. Понятие хабитуса. Потребительские практики и стили жизни. Противоречия между классом и хабитусом.

Основная литература:

Бурдье П. Социальное пространство и генезис «классов» / Бурдье П. Социология политики. М.: Socio-Logos, 1993. С. 55-97 или // Вопросы социологии, 1992. Т. 1., № 1. C. 17-36.

Радаев В.В., Шкаратан О.И. Социальная стратификация. 2-е изд. М.: Аспект Пресс, 1996. Глава 6, С. 157-166.

Дополнительная литература:

Бурдье П. От правила к стратегии / Бурдье П. Начала. М.: Socio-Logos, 1994. С. 93-116.

Бурдье П. Структура, габитус, практика // Журнал социологии и социальной антропологии, 1998. Т. 1, № 2. С. 44-59.

Шматко Н.А. «Габитус» в структуре социологической теории // Журнал социологии и социальной антропологии, 1998. Т. 1, № 2. С. 60-70.

Bourdieu, P. Distinction: A Social Critique of the Judgement of Taste. L.: Routledge and Kegan Paul, 1984. P. 466-484 or in: Grusky, D. (ed.). Social Stratification: Class, Race, and Gender in Sociological Perspective. P. 404-429.

Corrigan, P. The Sociology of Consumption. An Introduction. L.: Sage, 1997. Chapter 2. P. 2632.

Lin, N. Social Capital: A Theory of Social Structure an Action. N.Y.: Cambridge University Press, 2000. P. 2-12.

\section{Тема 18. Постмодернистский подход (С.Лэш, Дж. Урри)}

Переход от организованного к дезорганизованному капитализму. Производство благ и производство знаков. Когнитивная и эстетическая рефлексивность. Информационные и коммуникативные структуры. Потоки ресурсов. Дедифференциация экономики и культуры. 
Основная литература:

Радаев В.В. Экономическая социология: курс лекций. М.: Аспект Пресс, 1997. Глава 5, С. 90-91; Глава 8, С. 139-141; Глава 17, С. 260-262.

Lash S., and Urry J. Economies of Signs and Space. L.: Sage, 1994. P. 1-11.

Дополнительная литература:

Бодрийяр Ж. Система вещей. М.: Рудомино, 1999.

Веселов Ю.В. Экономическая социология постмодерна // Журнал социологии и социальной антропологии, 1998. Т. 1, № 1. С. 72-80.

Baudrillard, J. The Consumer Society: Myths and Structures. L.: Sage, 1998.

Carruthers, B. G. and S.L. Babb. Economy / Sociology: Markets, Meanings, and Social Structures. Thousands Oaks, CA: Pine Forge Press, 2000. Chapter 7. P. 181-215.

Lash S., and S. Urry. The End of Organised Capitalism. Cambridge: Polity Press, 1987. Introduction. P. 1-16.

\section{Тема 19. Экономическая социология в России}

Экономическая социология в советский период. Опережающая институционализация экономической социологии в постсоветский период. Исследовательские проекты и учебные программы. Методологическая ситуация. Наиболее и наименее развитые отрасли российской экономической социологии. Наиболее перспективные направления развития в будущем. Перспективы создания российской национальной теории.

Основная литература:

Веселов Ю.В. Экономическая история в России: история и современность // Журнал социологии и социальной антропологии, 1999. Т. 2, № 2. С. 63-70.

Радаев B.В. Экономическая социология: перспективы развития / Ядов В.А. (ред.) Социология в России, 2-е изд. М.: Институт социологии РАН, 1998. С. 253-263.

Радаев B.B. Есть ли шанс создать российскую национальную теорию в социальных науках? // Pro et Contra (лето 2000). T. 5, № 3. С. 202-214.

Дополнительная литература:

Бессонова О.Э. Институциональная теория хозяйственного развития России. Новосибирск: ИЭиОПП СО РАН, 1999.

Заславская Т.И., Рывкина Р.В. Социология экономической жизни. Новосибирск: Наука, 1991. С. 49-83.

Заславская Т.И. Социальная структура современного российского общества / Заславская Т.И. Российское общество на социальном изломе: взгляд изнутри. М.: МШСЭН, 1997. С. 226-253.

Заславская Т.И., Калугина З.И. (отв. ред.). Социальная траектория реформируемой России: Исследования Новосибирской экономико-социологической школы. Новосибирск: Наука, 1999. Раздел 1. С. 15-146. 
Кравченко А.И., Щербина В.В. Социология труда и производства / Ядов В.А. (ред.) Социология в России. 2-е изд. М.: Институт социологии РАН, 1998. С. 211-239.

Радаев В.В., Шкаратан О.И. Социальная стратификация. 1-е изд. М.: Наука, 1995. Глава 11.

Радаев В.В. Есть ли перспектива у российской политической экономии // Российский экономический журнал, 1998. № 9-10. С. 74-78.

Рывкина Р.В. Экономическая социология переходного периода. М.: Дело, 1998.

\section{Ориентировочные темы письменных работ по курсу «Современная экономическая социология»}

1. Каковы основные этапы становления экономико-социологической традиции?

2. В чем состоит специфика экономико-социологического подхода?

3. Как построить модель экономико-социологического человека?

4. Чем определяется различие между формальной содержательной рациональностью?

5. Чем различаются такие формы интеграции, как реципрокность, перераспределение и обмен?

6. Почему труд, земля и деньги считаются фиктивными товарами?

7. В чем состоит различие старой и новой экономической социологии?

8. Можно ли объединить экономические и социологические предпосылки в рамках теории рационального выбора?

9. В чем состоит суть концепции структурной укорененности экономического действия?

10. Как разрешаются конфликты между разными способами координации хозяйственной деятельности?

11. Какими параметрами определяется конфигурация деловой сети?

12. Какова роль сетей в поиске работы и служебном продвижении?

13. Как сети обеспечивают гибкость в использовании ограниченных ресурсов?

14. Какова структура институциональных образований в хозяйственной сфере?

15. Можно ли с помощью трансакционных издержек измерить эффективность хозяйственных институтов?

16. Каковы основные типы взаимодействия государства и рынка?

17. В чем заключается специфика торга на бюрократических рынках?

18. Могут ли существовать универсальные модели организационных форм и экономического развития?

19. Что включает в себя неформальная экономика?

20. Каковы способы связи формальных и неформальных правил в хозяйственной деятельности? 
21. Каковы исторические тенденции в использовании труда в домашнем хозяйстве?

22. Как распределяется труд между супругами в домашнем хозяйстве?

23. Что означает культурная укорененность экономических отношений?

24. Из чего складывается денежная культура населения?

25. Откуда возникает множественность денег и денежных суррогатов?

26. В чем состоят преимущества и недостатки многокритериального стратификационного подхода?

27. Каковы исторические тенденции социально-профессиональной мобильности?

28. Каково значение экономического капитала среди других форм капитала?

29. Как соотносятся класс и хабитус?

30. Что происходит при трансформации производства благ в производство знаков?

31. В чем состоят принципиальные отличия экономической социологии в советский и постсоветский периоды?

32. Каковы наиболее перспективные направления развития экономической социологии в России? 


\title{
Конференции
}

$\boldsymbol{V R}$ Представляем обзор выступлений экономико-социологической секции IX Международного Симпозиума Интерцентра «Куда идет Россия?». Эта секция признана особенно успешной, такое получается не каждый год. Удачная тема, сильный состав докладчиков, фокусированное обсуждение, тон которому задавали институциональные экономисты А.Аузан, Р.Капелюшников и В.Найшуль, - все это вызвало заслуженный интерес. Пожалуй, никогда еще эта секция не привлекала к себе столько внимания.

\section{ПРИ КАКИХ УСЛОВИЯХ НАЧИНАЮТ РАБОТАТЬ ФОРМАЛЬНЫЕ ПРАВИЛА В СОЦИАЛЬНО-ЭКОНОМИЧЕСКОЙ СФЕРЕ?}

\author{
обзор работы секции IX Ежегодного Международного симпозиума \\ «Куда идет Россия?.. Формальные институты и реальные практики»
}

18-19 января 2002 г.

Попова Ирина Петровна

к.с.н., МВСШЭН

Email:popova@msses.ru

Общий замысел сессии заключался в обсуждении различных аспектов ситуации, сложившейся с выполнением законов в социально-экономической сфере. В ее центре существование в российской действительности механизма деформализации формальных правил и встраивания последних в неформальные отношения. Этот механизм сложился за годы реформ и в силу разных причин продолжает эффективно функционировать. Предметом разговора стали актуальные вопросы предпосылок «реорганизации» этого механизма, движения хозяйственной деятельности в сторону легализации и общей формализации правил. Как достигается соблюдение договоров между работодателями и работниками, поставщиками и потребителями? Что предпринимается, чтобы хозяйственные агенты платили введенные налоги, а государство выполняло свои заявленные обязательства перед гражданами?

Обсуждение открыло выступление А. Аузана (Институт национального проекта «Общественный договор»), посвященное анализу тенденций легализации и технологии общественного договора. В качестве новой тенденции он отметил очевидную в последние годы потребность в формализации и остановился на характеристике ее источников в экономике. Среди них - ситуация в «олигархическом бизнесе»: к концу 1990-х гг. он решил задачи раздела собственности и нуждается в спецификации прав собственности. Следующий источник - конкуренция в бизнесе. Элитные группы (или группы, имеющие долгосрочные стратегии на своих рынках) не выделились. На этом фоне проблема легализации становится проблемой стратегической, позволяющей индивидам гармонизировать свое положение в системе общественных отношений. Еще один источник связан с гражданским обществом: правозащитная деятельность, экологические проблемы, жилищное право и т.д.

По мнению докладчика, реальны два канала осуществления легализации: федеральная власть, утверждающая формальные правила, и социализация бизнеса, начавшаяся после 
1998 г. Во многом это вопросы «укрепления крыши дома», достижения конвенций. Механизмы осуществления этой цели заложены в новой контрактарной теории, объясняющей, как строятся взаимоотношения агентов с государством по защите установленных правил. По мнению докладчика, первый символический обмен сигналами в отношении заключения контракта состоялся. Следующим шагом должно стать обеспечение санкций. Среди мер - конкурентная система арбитражных судов. Одна из проблем - адаптация к данной сфере различных мер (налоговых платежей, пошлин, бюджетной автономии) из другой экономической среды.

В. Найшуль (Институт национальной модели экономики) обратил внимание на проблему нормального и ненормального, того, как ненормальное становится нормой. В основе дилемма: все должно быть цивилизованным («по-римски») или все должно быть своим («по-естественному»). В России это предполагает решение дихотомии «Россия - Русь»: культивирование горизонтальных институтов, поддерживающих горизонтальные отношения; литературные переводы с использованием опыта построения русского литературного языка. Последнее предполагает решение задачи поэтического перевода западной социально-экономической системы на русский язык (подстрочник - не адекватен). Важно найти то, что заставляет систему действовать. Как при переводе слов и определений важно понять, какие эмоции возникали при их произнесении, что вызывало такие эмоции, - так и в социальных исследованиях важно найти, что заставляет систему действовать.

P. Нуреев (Государственный университет - Высшая школа экономики), отвечая на вопрос «Почему не работают формальные правила?», привлек большой теоретикометодологический материал. В объяснении проблемы он остановился на характеристике двух подходов, существующих в экономике развития и сформулированных в работах Г. Мюрдаля и Э. де Сото. В первом случае акцентируется взаимосвязь национальноэкономической ментальности и экономических институтов, во втором - правовые нормы. Были проанализированы основные модели условий развития бизнеса, различные схемы перехода к новой экономике (Т. Фрей, С. Кузнец и др.). Один из ответов на поставленный вопрос состоит в том, что необходим «путь снизу», предполагающий рост благосостояния населения, использование внутренних ресурсов и делающий привлекательными нормы. При этом необходимо понимать, что ментальные ценности являются основой для формирования правил более высокого уровня.

Ряд выступлений был посвящен поведению предприятий.

Выступление Э. Панеях (Европейский университет в Санкт-Петербурге) «Неформальные институты и использование формальных правил: закон действующий vs закон применяемый» касалось проблемы несовпадения действия формальных правил с соответствующей теоретической схемой, а также особенностей селективности контроля над их выполнением. Эта проблема раскрывалась на материалах исследования деловых биографий предпринимателей. Из 36 случайно выбранных интервью тема селективности действия закона упоминалась практически во всех: 32 предпринимателя говорили об этом как о существенной части своей деловой биографии. Применение закона - верхняя планка действий власть имущих по отношению к нарушителю неформальных соглашений. Но поступать так со всеми невозможно. Степень выполнения закона определяется открытым или закрытым торгом. Суть выбора - в минимизации усилий человека. Ограничения, разделяющие правила на действующие и применяемые (селективно), связаны с масштабом бизнеса; качеством учета и 
компетентностью бухгалтера; построением человеческих отношений с инспектором (не взятки).

В выступлении А. Яковлева (Государственный университет - Высшая школа экономики) «Российская модель корпоративного управления: формальные правила, мотивации собственников и интересы регулирующих ведомств» также был отмечен момент ужесточения правил. Условия, определяющие подобное ужесточение, докладчик охарактеризовал через ответы на вопросы о том, кому это нужно сейчас и в чьих интересах это происходит. Нынешняя противоречивая ситуация в корпоративном управлении стала результатом импорта в начале и середине 1990-х гг. институтов, ориентированных на американскую модель с распыленной структурой собственности и созданием соответствующей нормативно-правовой модели, для чего у России не было соответствующих условий. «Разрыв» между этой моделью и нормативной базой проблемная зона. В снижении соответствующих издержек заинтересованы многие стороны: сами собственники и менеджеры, профессиональные участники рынка, акционеры, регулирующие органы.

E. Балабанова (Нижегородский государственный университет) остановилась на неформальных практиках в модернизации предприятий. Основу выступления составило исследование, проведенное на 216 предприятиях пищевой (мясной и молочной) промышленности в Нижегородской области и Литве. Было выделено две группы предприятий, условно обозначенных как «тяжеловесы» и «молодые лидеры» и различавшихся по времени своего создания, масштабам, степени влияния на хозяйственные стратегии, репутационным и неформальным аспектам. Показано, как алые предпрятия заключают между собой альянсы для обмена новациями, кооперируются друг с другом для борьбы с мелкими полулегальными предприятиями («ЧП-шниками»), в чем заинтересованы предприятия обоих типов. Рассмотрены особенности поведения в сфере сбыта, в осуществлении процедуры стандартизации, в отношении аренды помещений, оснащения оборудования; в разных сочетаниях и пропорциях здесь присутствуют формальные и неформальные стратегии.

Латов Ю.В. (Тульский филиал Юридического института МВД РФ) начал с предложения объединить усилия представителей разных дисциплин и консолидировать их на базе какого-либо издания, представив попутно альманах «Преступность и коррупция» и журнал «Экономическая теория преступной и правоохранительной деятельности» (см. также: http://corruption2suh.ru). В своем выступлении «Предприниматели и чиновники неразлучные враги или заклятые друзья? (этнологический подход)» Ю. Латов поставил задачу сравнительного анализа взаимоотношений предпринимателей и «грабящей руки» государства с точки зрения культурных традиций, существующих в той или иной национальной среде. За основу взято исследование развития бизнеса в пяти постсоциалистических странах (Польше, Словакии, Румынии, России, Украине), проведенное в 1997 г. При этом противопоставлялись подходы де Сото и Мюрдаля, акцентировавших в первом случае - правовые институты, во втором - традиционные ценности. Среди общих выводов автор выделил следующие: причины тотальной неформальности - в преобладании «азиатских ценностей», или «российского хозяйственного менталитета»; российская хозяйственная культура не знает понятия «честной наживы», возникает порочный круг отчуждения бизнеса от общества; конфуцианская модель капитализма более подходит для России.

Следующий блок выступлений касался сферы занятости. 
Р. Капелюшников (Российский экономический барометр, ИМЭМО РАН), раскрывая тему «Российская модель рынка труда: реальное и ирреальное», сопоставил реальный механизм рынка труда и механизм, который можно реконструировать по формальным рамкам. В первом и во втором случаях картины резко различаются. Несовпадение портрета российского рынка труда, составленного по статистическим данным, и портрета, в основе которого нормы и законодательство, является следствием нереализованности этого законодательства на практике. Последнее происходит в силу низкого уровня издержек, связанных с несоблюдением действующего законодательства. В итоге создан двухсекторный рынок труда (формальный и неформальный). В российском варианте неэффективно сочетание законодательства с высокими издержками найма рабочей силы и низким уровнем механизма принуждения к исполнению [enforcement]. По мнению выступавшего, выход - в сближении картин, т.е. в снижении издержек, связанных с соблюдением формальных правил, и повышении механизмов принуждения к исполнению. По его мнению, новый Трудовой кодекс - определенный шаг в эту сторону.

Выступление С. Барсуковой (Государственный университет - Высшая школа экономики) «Реформирование трудового законодательства: пожелания власти и ожидания людей» было посвящено, с одной стороны, анализу недавно принятого Трудового кодекса, а с другой, - отношению работников к нарушениям Трудового кодекса со стороны работодателей (на базе проведенного в 2001 г. исследования). Среди прочего было отмечено, что расхождения между двумя конкурировавшими вариантами проекта кодекса - профсоюзным и проправительственным - не столь существенны. В целом ситуация меняется мало, а результаты и последствия введения некоторых новых норм (например, об ориентации зарплаты на прожиточный минимум) кажутся недостаточно просчитанными. Весьма любопытны реакции наемных работников на нарушения их прав, которые они имеют согласно Трудовому кодексу - зачастую работники оправдывают подобную практику или, по крайней мере, не осуждают.

Открывая раздел, посвященный социальной сфере, Л. Овчарова (Независимый институт социальной политики) представила проект «Противоречия российской политики содействия сокращению бедности». Одна из характеристик современного рынка труда низкая оплата труда, определяющая дифференциацию бедного населения по зарплате. Это определяет особенности и практику современной социальной политики в отношении бедного населения, которая часто принимает адресный характер и осуществляется на базе региональных ресурсов. Еще одна черта этой политики - введенная с 2000 г. новая минимальная потребительская корзина, которая на 15-20\% превышает уровень 1992 г. В результате $50 \%$ населения могут претендовать на социальную помощь государства. Для анализа противоречий в политике социальной помощи были привлечены материалы сравнительного исследования в Санкт-Петербурге и малом городе Вязники. Один из парадоксальных выводов состоит в том, что самые бедные оказываются дважды дискриминированными; социальная политика помощи бедным представляет собой и поле для коррумпированных действий, и потенциал для реформаторских практик.

Я. Рощина (Государственный университет - Высшая школа экономики) проанализировала результаты исследования формальных и неформальных издержек поступления в вуз, проведенного в четырех российских регионах. Среди издержек оплата школы, оплата подготовительных курсов и взятки за поступление. Один из обсуждаемых вопросов - есть ли альтернатива этим видам издержек? В качестве допустимых практик при поступлении родители чаще всего называли связи, 
использование шпаргалок, взятки. Оплата в школе признается альтернативой взяткам. Отмечена тенденция ориентирования на профессиональное образование - при росте численности поступающих в вузы.

Сельскую проблематику раскрыло выступление Г. Родионовой (Росагрофонд) «Эффективный собственник в сельском хозяйстве». Были проанализированы основные типы реорганизации предприятий на разных этапах приватизации (по схеме «разделение» и по схеме «преобразование»), а также различные варианты дифференциации доходов в сельском сообществе. Привлечены материалы исследований сельских сообществ в Нижегородской и Орловской областях. 


\section{Конференция \\ «Социальная политика: реалии XXI века» Москва, 24-25 января 2002 г. \\ Добрякова Мария Сергеевна}

Email: mdobryakova@,fordfound.org

В двух номерах журнала в разделе «Проекты» публиковались материалы исследований, проводимых в рамках программы «Социальная политика: реалии XXI века» ${ }^{1}$. В январе 2002 г. в Москве прошла заключительная конференция стипендиатов четвертого раунда программы, где были представлены результаты проектов, реализованных в 2001 г. Тезисы выступлений можно найти на сайте организатора программы - Независимого института социальной политики:

http://www.socialpolicy.ru/programs/grant/competitions/grant2000.shtml.

Поэтому здесь приводятся лишь названия проектов и имена их участников.

- «Причины и масштабы распространения бедности городского населения России и адресная социальная помощь беднейшим» (Л.Н. Овчарова, М.С. Токсанбаева, В.И. Гришанов， И.И. Корчагина， М.А. Козлова， Р.И. Попова， Л.М. Прокофьева, М.А. Ищенко)

- «Социально-пространственная дифференциация населения Санкт-Петербурга» (Н.Р. Корнев)

- «Стартовые малые предприятия в российских регионах после кризиса 1998 г.: занятость, трудовые отношения и взаимодействие с локальными рынками труда» (Е.М. Бухвальд, А.Ю. Чепуренко, Т.Б. Обыдённова)

- «Неправовые трудовые практики и социальные трансформации в России» (Т.И. Заславская, М.А. Шабанова, С.Ю. Барсукова)

- «Региональный рынок труда: эмпирическое исследование регистрируемой безработицы» (И.А. Денисова, А.М. Донецкий, О.А. Колесникова, А.А. Федченко, Н.И. Лядова, Д.З. Клейман)

- «Профессиональное обучение и переподготовка в условиях структурной перестройки российской экономики: роль государственной службы занятости» (В. Кабалина, А. Алашеев, В. Бизюкова, П. Бизюков, А. Бобышев, И. Германов, Н. Гуськова, Н. Ильченко, И. Козина, А. Кузнецов, Т. Лыткина, Т. Металина, Е. Плотникова, Евг. Плотникова, С. Ярошенко)

- «Рабочая сила региона: образование, профессиональная подготовка, квалификация. Проблемы регулирования» (Т.Ю. Стукен, В.Ю. Мамаева)

- «Профессиональное образование в современной России: социальные детерминанты неравенства доступа, мотиваций и спроса» (Я.М. Рощина, М.А. Другов, О.Е. Кузина)

\footnotetext{
${ }^{1}$ См. Том 2, № 3, 5 (2001 г.).
} 
- «Разработка образовательной политики на уровне региона (на материале Московской области» (М.Л. Агранович)

- «Модель социального партнерства как инструмент обеспечения взаимной стабильности социальных учреждений села и сельских хозяйств в условиях формирующегося рынка» (Г.В. Манзанова)

- «Место низовых общественных организаций аборигенов Севера, Сибири и Дальнего Востока в социальной политике РФ» (А.Н. Калабанов)

- «Социальный работник как субъект социальной политики (на примере Республики Татарстан)» (М.Ю. Несмелова)

- «Социальный механизм взодействия системы социальной защиты на адаптацию лиц пожилого и старческого возраста (в контексте формирования социальных аттитюдов общества к старшему поколению)» (С.Г. Максимова)

- «Пожилой человек в сельской местности: родственные связи и межпоколенные трансферты (Е.И. Иванова)

- «Миграционная мобильность экономически активного населения российской провинции в контексте формирования новых жизненных стратегий» (С.В. Рязанцев)

- «Исследование возможности адаптации матерей-подростков в современных условиях (на примере Алтайского края)» (Е.А. Абрамова)

- «Семьи с наркозависимыми детьми: составляющие развития критической ситуации, возможности позитивного результата. Факторы проницаемости современной российской семьи для наркотиков» (Г.И. Саганенко)

- «Государственное администрирование, гражданская инициатива или коммерческое предприятие? Пути и механизмы включения новых антинаркотических практик в региональную социальную политику» (Е.Л. Омельченко)

- «Армия и город: экономическое поведение и адаптационные возможности групп населения Санкт-Петербурга, связанных с оборонным комплексом» (И.И. Травин)

- «Анализ социальной напряженности с закрытых административных территориальных образованиях (ЗАТО) как необходимое условие обеспечения социальной защиты населения в ходе реформирования Вооруженных Сил (РВСН)» (В.В.Грабарь, В.А. Трефилов). 